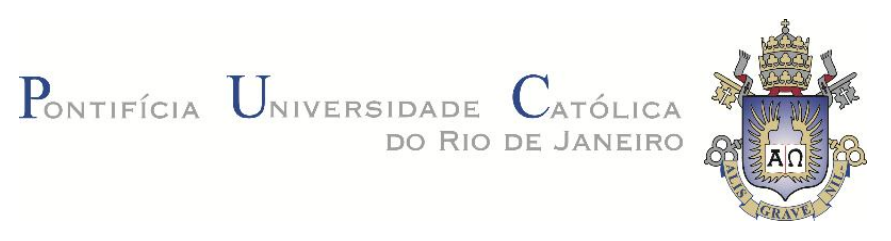

Carolyna Ferreira Barroca

Como se aprende a ser vadia?

Pedagogias de um movimento feminista

Dissertação de Mestrado

Dissertação apresentada ao Programa de PósGraduação em Educação da PUC-Rio como requisito parcial para obtenção do título de Mestre em Educação.

Orientador: Prof. Marcelo Gustavo Andrade de Souza

Rio de Janeiro

Abril de 2016 


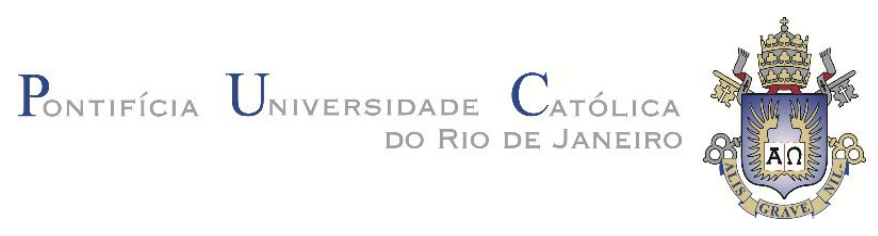

Carolyna Ferreira Barroca

\title{
Como se aprende a ser vadia? \\ Pedagogias de um movimento feminista
}

\begin{abstract}
Dissertação apresentada como requisito parcial para obtenção do grau de Mestre pelo Programa de PósGraduação em Educação da PUC-Rio.
\end{abstract}

Prof. Marcelo Gustavo Andrade de Souza

Orientador

Departamento de Educação - PUC-Rio

Prof. Rosália Maria Duarte

Departamento de Educação - PUC-Rio

Prof. Amana Rocha Mattos

UERJ

Prof ${ }^{a}$ Denise Berruezo Portinari Coordenador Setorial do Centro de

Teologia e Ciências Humanas

PUC-Rio

Rio de Janeiro, 12 de abril de 2016. 
Todos os direitos reservados. É proibida a reprodução total ou parcial do trabalho sem autorização da universidade, da autora e do orientador.

\section{Carolyna Barroca Ferreira}

Bacharelado e Licenciatura em História pela Universidade do Estado do Rio de Janeiro. Especialização em Ensino de História e Ciências Sociais pela Universidade Federal Fluminense e em Gênero e Sexualidade certificada pelo Instituto de Medicina Social da Universidade do Estado do Rio de Janeiro.

Ficha Catalográfica

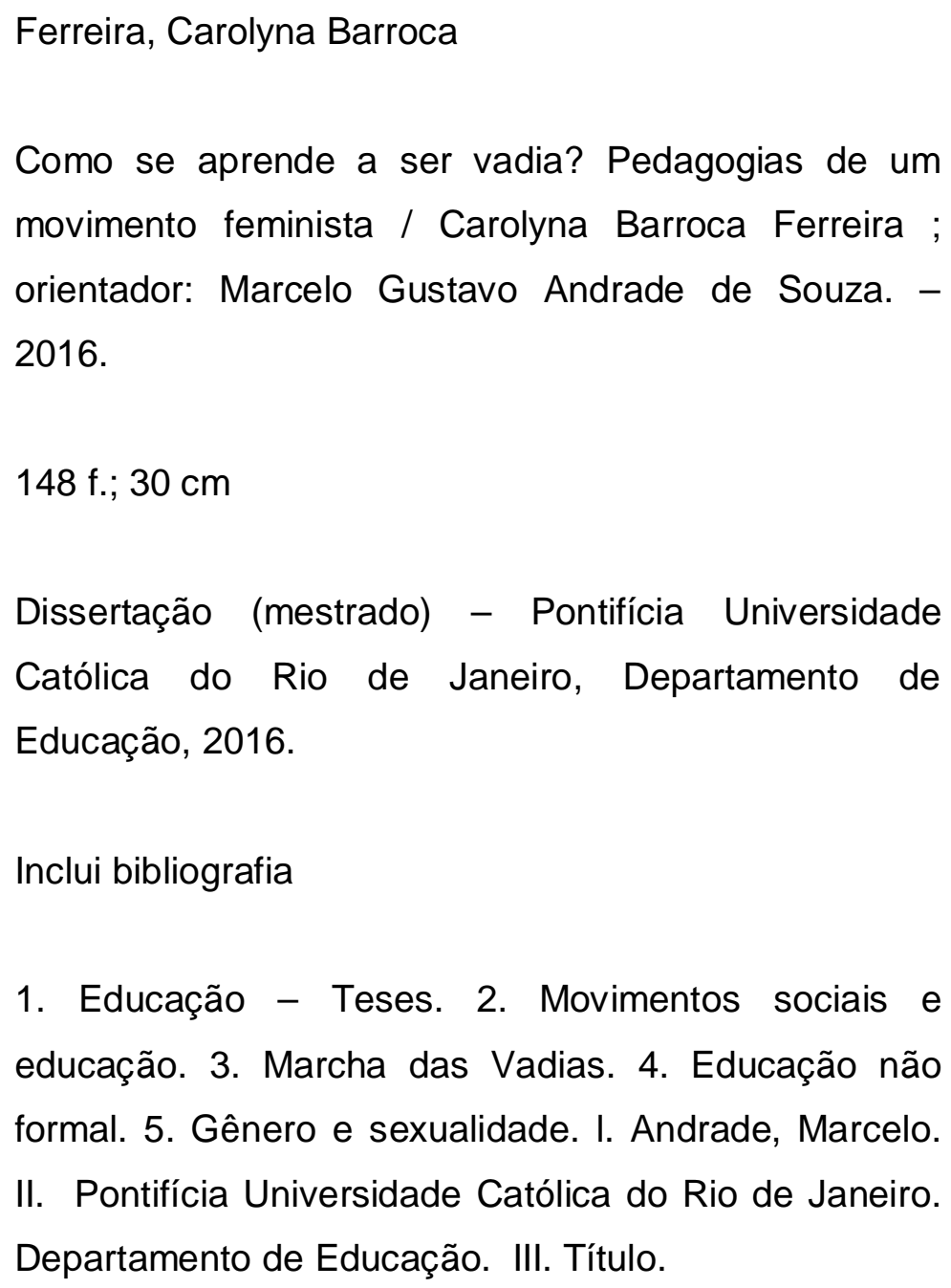

1. Educação - Teses. 2. Movimentos sociais e educação. 3. Marcha das Vadias. 4. Educação não formal. 5. Gênero e sexualidade. I. Andrade, Marcelo. II. Pontifícia Universidade Católica do Rio de Janeiro. Departamento de Educação. III. Título. 
Dedico a todas as mulheres de luta que me constroem cotidianamente. 


\section{Agradecimentos}

Esta, com toda a certeza, é a parte mais fácil de todo o processo de escrita que se sucede neste trabalho. Foram dois anos intensos e de muita luta. Aprendi muito, ouvi muito, falei demais e pude até retornar ao sentimento despertado de minha militância estudantil da graduação. Entendi mais de história e de teoria educacional, pouco de política e mais do que nunca de práticas pedagógicas. Reaprendi a escrever e aprendi sobre pesquisa e metodologia de um jeito que nunca mais esqueço. A tudo isso eu agradeço ao Programa de Pós Graduação de Educação da PUC-Rio e ao incentivo do CNPq por meio de bolsa de fomento que me manteve no programa. Obrigada também a todos os professores do programa que na sala de aula e fora dela me ensinaram sobre a vida acadêmica e sobre as facilidades e dificuldades de ser pesquisadora. Agradeço ainda aos membros da banca que disponibilizaram seu tempo para acompanhar o resultado da pesquisa.

Agradeço ao meu pai Maxwell, minha mãe Janete e às minhas irmãs Nathalia e Millena. Vocês são pessoas por quem tenho um amor incondicional e que sem o apoio de vocês, mesmo que virtual, na maior parte do tempo (infelizmente) eu não estaria aqui. Saber que sou motivo de orgulho pra vocês me faz sentir algo que nem todas as palavras do mundo expressam. Desejo de coração que este título nos traga maior possibilidade de encontros e de abraços. Todos vocês se sacrificaram de alguma forma para que esta conquista se concretizasse, portanto, sintam-se parte dela, pois sem vocês eu não sou nada.

Agradeço também a todas as pessoas que compõem o grupo de pesquisa que participo, GECEC, por todo apoio, ensinamento e por cada $2^{\mathrm{a}}$ feira que estivemos juntos (e ainda estaremos, assim espero). Em especial agradeço à Helena Araújo, eterna professora da UERJ, ao querido Dorvillé por todos os conselhos de vida e de pesquisa, ao Felipe Bastos, um querido amigo que a PUC me deu, à minha companheira de viagem e de decolonialidade Claudia Miranda e suas lindas pontes de contato, à Raquel Pinho por sua escuta e leitura atenta e por 
aturar vários desabafos de pesquisa, principalmente nesse último ano. Agradeço também à minha querida Mônica Almeida que me equipou tecnologicamente quando mais precisei e me acalentou como uma mãe em nossas viagens de retorno pra casa e à linda e querida Sandra, mulher negra e guerreira que me dá ânimo e energia a cada encontro. Um agradecimento todo especial à Marina, que sempre encheu de doçura os dias de reunião, estágio e frequência constante no mezanino. Cada um dos integrantes do grupo me ajudou a chegar aqui da sua maneira e saber que nossos caminhos ainda vão trilhar juntos por um bom tempo me conforta.

Não vejo como o final desses dois anos poderia ser melhor se não fosse a presença dos que estiveram constantemente comigo nesta caminhada. Na alegria, na tristeza, no bar e na sala de aula, na biblioteca e nas casas de um e de outro, nos desesperos constantes (quase sempre) e nos poucos momentos de alívio, na dívida (eterna companheira dos bolsistas) e na fartura (dos amigos bolsistas FAPERJ, que agora se encontram nada fartos), na saúde e na doença (mais doença do que saúde, admito), nos ensaios teórico metodológicos, na diferenciação de quadro de tabelas, na descoberta de que tudo é figura e nos áudios que insistiam em chegar, devo tudo a cada um de vocês meus amigos de turma, de jornada e de vida. Com vocês, superei as dificuldades de pesquisa, de escrita, os gerúndios, uma decepção amorosa, várias desilusões, crushs, a partida do meu companheiro Che, depressão, mudanças e continuidades. Agradeço a turma inteira, a melhor turma do mundo. Em especial agradeço à minha amiga-irmã-que-lê-meus-pensamentos, Roberta, que me acompanha desde a graduação. Tomamos juntas a decisão de embarcar nessa loucura e chegamos ao fim mais unidas do que nunca. Agradeço também à minha pessoa mais linda em todos os sentidos e competente do mundo, Laryssa, e desejo que seus áudios nunca parem de me fazer rir, mesmo que você esteja sempre desesperada neles. Ao meu amigo irmão Rômulo, sem você, meu querido, não sei o que faria, mesmo que a gente brigue um pouco. Na certa você é uma das minhas almas gêmeas dessa vida. Elio, meu querido amigo que me mostra o poder e a loucura da desconstrução diária. Que está sempre do lado dos que ama, mesmo quando não se sente inteiro. João, uma das pessoas mais inesperadas do mundo, das amizades mais fiéis do universo. Mesmo que você teste a cada (des)encontro a paciência dos que te querem bem, agradeço por seu ombro enquanto eu chorava e pelo seu apoio em todo esse processo. Exemplos de superação e de reinvenção 
cotidiana. Jéssica e sua juventude que encanta e que me deu tantas alegrias se mostrando forte quando eu mais precisei e se tornando alguém a quem eu quero sempre proteger. Joyci, obrigada por sua casa e por tudo. Angela, que sempre divou em meu coração, com você aprendi mais sobre vida, sobre a doçura e sobre o cuidado com o próximo. Érika, Carla, Lili e Rosa, as mulheres mais batalhadoras que eu tive o prazer de conhecer na vida. Obrigada por me deixarem fazer parte da vida de vocês. Sem a leitura de cada uma de vocês, as companhias para o café e as escutas sempre atentas não sei o que faria. Olhamos e comentamos sobre os nossos avanços físicos e metodológicos, mas a nossa construção coletiva foi o maior ganho de todo esse processo para mim. Espero de coração que nossos caminhos sempre estejam unidos. Amo vocês. Cada um de vocês.

Agradeço, em especial, a você Fernando, companheiro desta vida. Amor verdadeiro e infinito de todas as vidas. Com sua dedicação, carinho e amizade pude atravessar cada obstáculo destes nossos nove anos de caminhada. Ao seu lado aprendi o sentido do amor, o sentir do mais puro afeto, sobre a presteza do mais frequente cuidado, sobre o verdadeiro peso das palavras e aprendi também a lidar com as consequências das escolhas. Você é parte indispensável da minha vida.

Agradeço ainda a todos os meus amigos e minhas amigas que estiveram torcendo por mim durante esses dois anos e durante toda a minha vida. Dedico também esta conquista a cada um de vocês.

Agradeço ao Movimento Marcha das Vadias do Rio de Janeiro e a cada entrevistada. Aprendi muito com vocês e sou, definitivamente, outra mulher depois de nossa experiência e militância.

E, por fim, mas não menos importante, agradeço ao meu orientador Marcelo que foi e ainda é um amigo, inspiração e exemplo. Obrigada pela paciência, ajuda, parceria e todo o processo de ensino e aprendizagem que envolveram uma nova didática em nossa relação orientanda e orientador destes anos. 


\section{Resumo}

Barroca, Carolyna Ferreira; Souza, Marcelo Gustavo Andrade de. Como se aprende a ser vadia? Pedagogias de um movimento feminista. Rio de Janeiro, 2016. 148p. Dissertação de Mestrado - Departamento de Educação, Pontifícia Universidade Católica do Rio de Janeiro.

Esta pesquisa objetiva analisar como um movimento social feminista desenvolve estratégias formativas de seus quadros ou mesmo de simpatizantes à causa das mulheres. Optou-se por um estudo de caso e foi analisado a Marcha das Vadias do Rio de Janeiro de 2015. Por meio de uma pesquisa participante, observações de reuniões e entrevistas semiestruturadas, os dados coletados viabilizaram a escrita da pesquisa em três temas-chave. O primeiro se refere à militância no movimento como fonte de empoderamento das mulheres, com especial ênfase para a construção da liberdade do corpo. Neste tema-chave, também se observou a intenção de subverter a ordem social e os aspectos culturais de dominação na qual as diferentes mulheres estão subjulgadas historicamente. $\mathrm{O}$ segundo tema-chave relaciona diretamente à temática da diferença na educação, com a discussão da interseccionalidade, defendida pela Marcha das Vadias RJ 2015, apontando os avanços e as barreiras da coexistência de diferentes níveis de opressões em nossas sociedades e também dentro do próprio movimento. $\mathrm{O}$ terceiro tema-chave discute a percepção das participantes da Marcha das Vadias RJ 2015 sobre o que aprenderam dentro do movimento e quais são as potencialidades pedagógicas que o mesmo apresenta para as questões contemporâneas nas lutas feministas. Por fim, foi possível concluir que a Marca das Vadias do Rio de Janeiro em 2015 é um movimento social potente para uma formação contra-hegemônica na qual o respeito pelas diferenças e as discussões de gênero e de sexualidade se apresentam como possíveis, bem como os limites e os avanços a serem considerados em outros espaços para a defesa de uma educação intercultural.

\section{Palavras-chave}

Movimentos sociais e educação; Marcha das Vadias; Educação não formal; Gênero e sexualidade. 


\section{Abstract}

Barroca, Carolyna Ferreira; Souza, Marcelo Gustavo Andrade de. (Advisor). How to be a slut? Pedagogies of a feminist movement. Rio de Janeiro, 2016. 148p. MSc. Dissertation - Departamento de Educação, Pontifícia Universidade Católica do Rio de Janeiro.

This research aims to analyze how a social feminist movement develops training strategies or maybe relates to women causes. We studied and analyzed the Rio's 2015 SlutWalk. Using researches, meeting notes and interviews, it was possible to divide this paper in three keys topics. The first one refers to the militancy seen in the movement as a proof of women empowerment, specially when it comes to choices of freedom over the body. Thereby, we also observed the intention to subvert the social order and the cultural aspects of leadership in which many women are historically subjected. The second key topic is directly related to the differences in education, also discussing the intersectionality defended by Rio's 2015 SlutWalk. It indicates the progress and barriers of coexistence in different levels of oppressions in our society and inside the movement. The third key topic discusses the perception of what the walk participants say they have learned from the movement and what kind of educational potential it has in the contemporary issues in women's struggles. Finally, concluded the Rio's 2015 SlutWalk is a social moviment for a strong way for a counter-hegemonic formation in which respect for gender equality and sexuality discussions are as possible as boundaries and advances to be considered in other areas for an intercultural education.

\section{Keywords}

Social movements and education; Rio's Slutwalk; Non-formal education; gender and sexuality. 


\section{Sumário}

1 Tornar-se pesquisadora e manter-se militante

1.1. Levantamento bibliográfico ou sobre o mapeamento das fronteiras

1.2. Questões de pesquisa ou perguntas às fronteiras

1.3. Objetivos ou os alvos na fronteira

1.4. Opções metodológicas ou sobre como se movimentar nas fronteiras

1.5. Estrutura da dissertação ou sobre um novo mapa para a fronteira

2 Da Hierarquização à leveza: de movimentos sociais à "micareta política"

2.1. A militância das mulheres

2.2. O campo: a pesquisa como vivência

2.3. A vontade das mulheres em marcha pelo mundo

2.4. A Marcha das Vadias do Rio de Janeiro: panorama de pesquisas e de observações

2.5. A Marcha como "incubadora feminista": características do campo

3 A militância do corpo por gêneros e sexualidades

3.1. "Pedagogia vadia": sobre as formações possíveis

3.2. Percepções iniciais acerca de gênero e sexualidade

3.3. Novos feminismos em marcha: transgressões culturais

3.4. O corpo como caligrafia de protesto

3.5. No Brasil, corpos despidos só no carnaval!

4 Sobre as diferenças que desafiam o movimento

4.1. A academia e a militância: uma fronteira possível? 82

4.2. Os desafios da horizontalidade como proposta 85

4.3. O movimento em três palavras: definição do campo 90

4.4. A interseccionalidade na prática militante 
5 Aprender a ser "vadia"? Das falas e testemunhos militantes

5.2 Uma pedagogia feminista

5.3 Uma rede de vadiagem

115

5.4 Espaços pedagógicos: opções do campo

118

6 Considerações finais

123

7 Referências bibliográficas

129

6 Apêndices

134

6.1. Termo de Consentimento Livre e Esclarecido

134

6.2. Ficha de Cadastro

135

6.3. Roteiro de Observação

136

6.4. Roteiro de entrevista

138

6.5. Lista de códigos

139

7 Anexos

142

7.1. Parecer do Comitê de Ética da PUC-Rio

142

7.2. Manifesto 2014

143

7.3. Manifesto 2015

146 


\section{Lista de Quadros}

Quadro 1: Levantamento de trabalhos da Anped ...........................................22

Quadro 2: Levantamento de trabalhos do Fazendo Gênero ............................... 23

Quadro 3: Levantamento de trabalhos em revistas acadêmicas .......................... 24

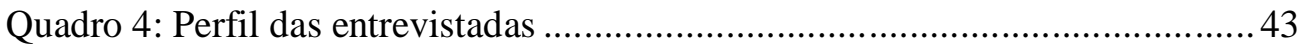




\section{Lista de Figuras}

Figura 1: Cartaz sobre a relação entre biologia e a identidade de gênero............. 62

Figura 2: Contestação de papéis da mulher.......................................................63

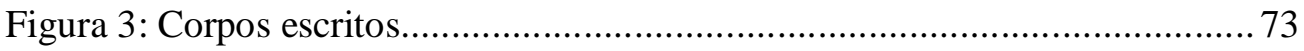

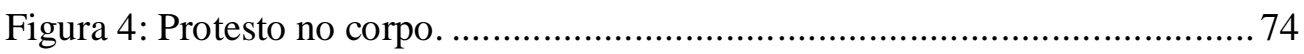

Figura 5: Roupas performáticas............................................................. 76

Figura 6: Exemplo de informações iconográficas. ............................................. 89

Figura 7: Definição da Marcha das Vadias ....................................................... 90

Figura 8: Cartazes do contexto político. ....................................................... 110

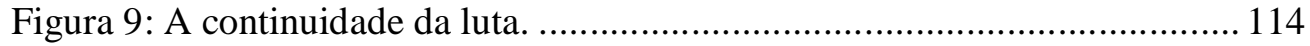

Figura 10: Gráfico de espaços educativos..................................................... 120 
Ser capaz de recomeçar sempre, de fazer, de reconstruir, de não se entregar, de recusar burocratizar-se mentalmente, de entender e de viver a vida como processo, como vir a ser... (Paulo Freire) 


\section{Tornar-se pesquisadora e manter-se militante}

Nesses dois anos, nos quais a rotina acadêmica foi mais intensa em minha vida, um dos aprendizados foi a certeza de que a definição de um objeto de pesquisa passa por diversas etapas. Algumas experiências de vida podem ser motivadoras para a construção do problema de pesquisa, que culmina em sua transformação em tema, perguntas, objetivos e opções metodológicas. Este foi, e ainda é, o meu caso e, portanto, o que tem definido minha trajetória acadêmica.

Ainda que um pouco mais afastada nos últimos tempos, considero-me uma militante dos movimentos sociais. Estive presente em diferentes manifestações sociais, tendo acompanhado também as Jornadas de Junho de $2013^{1}$. Atuando em espaços de militância social e tendo me formado professora de história, pude vivenciar algumas das possibilidades pedagógicas desses espaços. Minha maneira de ver o mundo e de defender minhas convicções sofreram alterações no contato com os movimentos sociais que militei mais diretamente e/ou que acompanhei ainda que de longe. O processo de empoderamento pessoal, oriundo da rotina de militante, me fez pertencente a uma nova identidade e percebi, com os olhos iniciantes de uma pesquisadora, o quão frutífero este campo é para a formação humana, social e política. Ainda que, comumente, considerado um ambiente de educação não formal, passei a entender que os movimentos sociais também são espaços de construção de conhecimentos e de aprendizagens para a transformação social.

Neste sentido, vale a pena retomar aqui minha trajetória a fim de explicitar como cheguei ao tema de pesquisa. Ingressei no curso de História na Universidade do Estado do Rio de Janeiro (UERJ) movida pela curiosidade de aprender mais

1 As Jornadas de Junho de 2013 demarcaram um descontentamento de grande parte da população com a atuação do Estado no setor de bens e serviços. Iniciaram-se com protestos convocados pelo Movimento Passe Livre (MPL), que questionava o aumento das passagens de ônibus. Com intensa participação popular, as manifestações foram marcadas pela heterogeneidade nas reivindicações e pela truculência na resposta das forças armadas do Estado. Em que pese as contradições das Jornadas de Junho de 2013, entendo-as aqui no contexto das reivindicações do MPL. 
sobre Antiguidade Oriental e pela busca de pôr em prática uma utopia. Naquele momento, entendia que a escola era uma base importantíssima da nossa sociedade e que, como tal, ela teria o poder de modificar a sociedade, como se fosse um campo externo à mesma. Posso afirmar que possuía uma visão redentora e ingênua sobre o papel da educação escolar na sociedade (LUCKESI, 1990)². Evidenciando a inocência teórica daquele momento, também queria mudar o mundo por meio da sala de aula, através do aumento de debates que levassem os educandos $^{3}$ a uma conscientização crítica para práticas que subvertessem a estrutura da sociedade (FREIRE, 1983). Hoje, posso afirmar que minhas formações teóricas apontam que a defesa da perspectiva freireana, isto é, libertadora (FREIRE, 1983; LIBÂNEO, 1990), evidencia possibilidades de transformar o meio no qual vivo. Uma educação que fomente o questionamento da realidade, que desenvolva a consciência crítica e que busque uma relação horizontal baseada no diálogo, contribui significativamente para a formação de uma base subversiva das estruturas sociais vigentes.

Durante a minha formação, meus interesses de pesquisa se alteraram quando tive contato com as disciplinas de ensino de História, principalmente, a partir das aulas de algumas professoras que possuíam atuação direta na educação básica. Concomitante a isso, a militância dentro do movimento estudantil e as discussões sobre currículo, formação de professores e função social do conhecimento me levaram, cada vez mais, ao campo de pesquisa da Educação. Ainda nesta trilha, minha monografia de conclusão de curso foi um ensaio crítico sobre as atuais condições que se encontram a educação básica pública no estado do Rio de Janeiro.

Naquele período, também no campo da militância, fiz parte de uma organização partidária que buscava, por meio da atuação conjunta com as classes populares, um fim revolucionário. Nesta organização, éramos somente duas mulheres na atuação do Rio de Janeiro. Como mulher e militante, pude perceber

2 Nesta época, minha percepção sobre a função social da educação era a de que esta poderia integrar harmonicamente toda a sociedade. Segundo Luckesi (1990), esta perspectiva revela uma visão de que a escola seria uma instituição externa à sociedade e que, estando nesta posição, poderia redimi-la de todo e qualquer problema.

3 A utilização deste termo se refere à compreensão que tenho hoje sobre a educação e a função social da escola, do professor e do processo de ensino e aprendizagem, no qual Freire (1983) defende que os educandos possuem um papel ativo neste processo e que o professor, além de ensinar, também adota a postura de aprender. 
diversas atuações e situações machistas que fazem parte da estrutura social mais ampla e que eram reproduzidas na militância política, como por exemplo, a maior valorização das falas dos companheiros e também uma hierarquização que os privilegiava tanto na divisão de tarefas internas quanto nas ações coletivas. Tal percepção também me mostrou como a lógica sexista e machista fazia parte da minha vida e como eu também reproduzia situações de opressão e/ou era conivente, inclusive nos casos em que era a vítima. Perceber isso me fez querer aprender mais sobre as relações de gêneros, sexualidades e as estruturas de poder que as englobam, bem como as que surgem a partir delas. Assim, fui buscar uma formação na universidade, ainda que tivesse muitas críticas a esta instituição no que se refere a sua função social e a sua defesa eurocêntrica na valorização de conhecimentos.

Após a graduação, busquei duas especializações: a primeira foi na Universidade Federal Fluminense (UFF) no Programa de Pós-Graduação em Educação com foco em Ensino de História e Ciências Sociais, que objetivava conhecer mais sobre as relações entre História e Educação; e a segunda foi em Gênero e Sexualidade, promovida pelo Instituto de Medicina Social da Universidade do Estado do Rio de Janeiro (UERJ), no qual busquei maior aporte teórico sobre as questões relativas aos gêneros, sexualidades, diversidades e sobre as desigualdades produzidas pela hierarquização destas.

Com os estudos sobre gêneros e sexualidades, tinha a pretensão de incentivar a criação de um curso de formação a ser oferecido para os companheiros da organização que militava. Meu objetivo era contribuir para que as práticas machistas e sexistas, que tanto me incomodavam, fossem minimizadas. Buscava a percepção da contradição entre o discurso de busca de igualdade e as reproduções de sistemas de opressão nas relações entre homens e mulheres que se faziam presente no movimento. No entanto, a dificuldade de se estabelecer um diálogo sobre tais questões com aqueles com quem compartilhava uma perspectiva política e a percepção de que a educação sozinha não poderia mudar tudo e todos me fizeram sair da organização. Busquei, então, a formação de um coletivo feminista na universidade e um aprofundamento teórico em cursos de formação em questões relativas à temática. Na tentativa de unir os dois interesses que marcaram e modificaram minha trajetória pessoal, acadêmica e militante, 
busquei no Mestrado em Educação entender mais sobre as práticas pedagógicas dos movimentos sociais, em específico, de movimentos feministas.

Compreendo que os movimentos sociais, mesmo os que compartilham bases teóricas, possuem diferentes formas de atuação e, portanto, não podem ser generalizados. Assim, motivada por minha trajetória e partindo da literatura sobre o tema (ARROYO, 2003, 2014; CASTELLS, 2013, 2015; GOHN, 2011a, 2011b, 2012, 2014; HOOKS ${ }^{4}$, 2013; MESQUITA, 2003, 2006, 2008), desenhei o meu projeto de pesquisa como um exercício de aprofundamento nas práticas pedagógicas existentes dentro de movimentos feministas a partir de um estudo de caso.

É importante delimitar que esta investigação se estabelece dentro de um território específico, isto é, em uma região de fronteira no diálogo de três campos de estudo: movimentos sociais, gêneros e sexualidades e educação não formal. E a noção de fronteira me ajudou a elaborar o desenho de pesquisa.

Para o melhor entendimento do conceito de uma pesquisa em uma área de fronteira, Martins (1997, p. 150) afirma compreender este conceito como

essencialmente o lugar da alteridade. É isso que faz dela um lugar singular. À primeira vista é o lugar de encontro dos que, por diferentes razões, são diferentes entre si, como o índio de um lado e os civilizados do outro; como os grandes proprietários de terra, de um lado e os camponeses pobres, de outro. Mas o conflito faz com que a fronteira seja essencialmente, a um só tempo, um lugar de descoberta do outro e de desencontro.

As delimitações da fronteira não são rígidas e estáticas, tornando-se um uma área de intenso diálogo. As relações entre os três campos desta pesquisa proporcionam maior possibilidade de entendimento sobre as questões que regem e circundam o campo, bem como as que são originadas deste território tão específico.

\section{1.}

Levantamento bibliográfico ou sobre o mapeamento das fronteiras

Definido o tema da pesquisa, em consonância com minha trajetória, busquei identificar grupos de discussão em eventos acadêmicos reconhecidos na área de

$4 \mathrm{O}$ sobrenome hooks refere-se a autora bell hooks, um pseuodônimo de Gloria Jean Watkins, uma escritora norte americana. Segundo ela, a grafia do seu nome é em minúsculo porque saber quem ela é não importa, mas sim o que escreve. 
educação e ciências sociais, envolvendo a temática. Pude perceber que a existência de tais grupos indicava que os estudos relacionados às relações entre movimento social e educação ganham cada vez mais importância. No entanto, pude perceber também que os estudos sobre práticas pedagógicas de movimentos sociais feministas ainda encontram lacunas a serem preenchidas, o que me motivou mais para a pesquisa. Assim, esta dissertação buscou avançar nos debates sobre as fronteiras entre educação, movimentos sociais e questões de gêneros e sexualidades, pois elas parecem, ainda, pouco exploradas.

Se por um lado, a escola - enquanto educação formal - tem sido desafiada pelas temáticas da diferença (ANDRADE, 2009), por outro, os movimentos sociais - enquanto outros espaços pedagógicos e formativos - não estão isentos de também enfrentá-las. Segundo Andrade (2009; 2015), a escola enfrenta um grande desafio para aprender a lidar com as questões de gêneros, sexualidades, raças, religiões, identidades, dentre outras temáticas que formam uma sociedade multicultural.

Recentes pesquisas desenvolvidas na escola apontam que a maneira mais comum que a escola lida com a diversidade é pelo silenciamento. Andrade e Câmara (2015) tratam desta ação como uma imposição, uma atuação proposital de não deixar falar, não deixar expor, não ouvir os diferentes. No entanto, tais dificuldades não são exatamente uma novidade, mas remontam ao período da institucionalização escolar e também da sua ampliação com vistas à democratização. A escola foi criada para atender a uma classe social específica, as elites econômicas e culturais, que a tinha como fonte de transmissão da cultura científica, filosófica e moral. Com a criação dos Estados Modernos a instituição escolar universalizou-se e as classes populares passaram a também ocupar estes espaços (SHIROMA, 2004; OLIVEIRA, FONSECA e SANTOS, 2010), levando consigo suas formações culturais e seus saberes (FREIRE, 1996) que abalaram, e ainda abalam, sua estrutura normativa. Mesmo com diversos avanços promovidos por atuações de movimentos sociais, políticas públicas e educacionais, o ambiente formal de ensino ainda está marcado pela homogeneização como uma característica imperativa de seu cotidiano. Os movimentos sociais se apresentam, então, como outros espaços de formação pedagógica, em paralelo ao espaço escolar, mas este ainda possui maior prestígio na função de consolidar conhecimentos historicamente legitimados. 
Dito isto, é preciso deixar claro que esta pesquisa apresenta os processos de ensino e aprendizagem existentes dentro dos movimentos sociais e não em espaços escolares. Nesta pesquisa, não foco nas relações entre o campo da educação formal, não formal e informal (LIBÂNEO, 2007) e, tampouco, em como os movimentos sociais se relacionam e disputam espaço no cotidiano escolar, no currículo ou na formação dos professores. Ainda que sejam temáticas importantes, este não é o centro deste trabalho, mas sim a possibilidade de vislumbrar maneiras pelas quais as formações pedagógicas oriundas das militâncias lidam com a diversidade.

Das possibilidades de tipos de movimentos sociais, optei por me debruçar sobre os movimentos feministas no intuito de, além de fazer uma interseção com minha trajetória pessoal, militante e acadêmica, contribuir com a superação de algumas lacunas que este campo de estudo ainda evidencia. Definido o tema da pesquisa, fez-se necessária, então, a busca por estudos que me oferecessem maior aporte teórico e metodológico. Minha primeira definição foi a seleção de palavras chaves. Diversas possibilidades que relacionassem as práticas pedagógicas e os movimentos feministas se apresentaram. Assim, no levantamento bibliográfico, optei por três palavras centrais para a primeira etapa de minha pesquisa: (i) relações de gêneros; (ii) movimentos sociais e (iii) práticas pedagógicas ${ }^{5}$. O termo Marcha das Vadias foi utilizado, mas não evidenciou nenhum trabalho que pudesse auxiliar na pesquisa.

Para compreender e definir melhor meu campo de pesquisa realizei um levantamento bibliográfico para definir quais seriam as categorias de análise teórica e conceitual da dissertação. Por meio do refinamento dos descritores de palavras-chave em três eixos principais, destaquei os conceitos chaves e alguns autores essenciais para a revisão teórica. Foram realizados três exercícios de levantamento bibliográfico, visto que a inclusão das três palavras chaves (ou suas variações, tais como gênero, sexualidade, movimentos feministas, educação não formal e pedagogia) nem sempre trouxeram resultados com uma articulação direta entre os termos citados.

5 A escolha deste termo partiu da constatação de que ele costuma ser o mais utilizado em pesquisas que busquem a práticas educacionais, isto é, a forma de se colocar a educação enquanto formação humana individual e coletiva em ação. 
- O primeiro eixo tratou da revisão de bibliografia sobre as relações existentes entre movimentos sociais e práticas educacionais/pedagógicas. Neste eixo busquei também as relações entre os movimentos feministas e práticas educacionais/pedagógicas.

- O segundo eixo tratou da revisão bibliográfica sobre as interlocuções existentes entre práticas educacionais/pedagógicas e relações de gêneros;

- E, por fim, um último eixo foi o levantamento bibliográfico sobre as interações existentes entre relações de gênero e movimentos sociais, focando nos movimentos feministas.

O levantamento bibliográfico foi realizado para cada eixo descrito tendo as seguintes bases de busca: (i) Banco de Teses e Dissertações da Capes; (ii) revistas qualificadas da Área de Educação, segundo os critérios do Qualis Periódicos da Capes; (iii) anais das Reuniões Nacionais da ANPEd e outros eventos significativos para a pesquisa. A escolha dos trabalhos, para esta etapa, foi feita a partir da leitura dos resumos disponibilizados. Posteriormente à leitura dos resumos, o material encontrado foi estudado e catalogado a fim de se construir o referencial teórico desta pesquisa.

Além disso, as obras de Arroyo (2003; 2014), Gohn (2011a, 2011b, 2012, 2014), e Castells $(2013,2015)$ embasam as discussões teóricas, tendo em vista que apontam abordagens importantes ao campo deste estudo sobre movimentos sociais e a sua pedagogia. A perspectiva de interculturalidade decolonial trazida por hooks (2013) e os trabalhos de Crenshaw (2002) que trazem definições de feminismo interseccional auxiliaram na compreensão do movimento estudado. Estas discussões foram acrescentadas à pesquisa desde a confecção do projeto, pois, após a minha entrada no campo, percebi que havia a necessidade de buscar apoio teórico nestas autoras para melhor explicar o objeto de pesquisa.

Para compreender melhor meu tema e aprofundar as discussões e argumentações, o diálogo com outras pesquisas foi fundamental. Inicialmente, realizei um levantamento em três Grupos de Trabalho (GTs) da Associação Nacional de Pós-Graduação e Pesquisa em Educação ANPEd, que apresentam propostas de discussão sobre movimentos sociais, educação popular e gêneros e sexualidades. A busca foi realizada nos GTs Movimentos sociais, sujeitos e processos educativos (GT - 03), Educação popular (GT - 06) e Gênero, 
sexualidade e educação (GT - 23), entre os anos de 2010 e 2014. O quadro abaixo (Quadro 1) sinteteiza o resultado das buscas:

\section{Quadro 1: Levantamento de trabalhos da Anped}

\begin{tabular}{|c|c|c|c|}
\hline Ano & Grupo de Discussão & Autor & Título do Trabalho \\
\hline 2014 & Educação Popular & $\begin{array}{ll}\text { Fabiana } & \text { Rodrigues } \\
\text { de Sousa } & \end{array}$ & $\begin{array}{l}\text { Participação Popular e Engajamento de } \\
\text { Prostitutas na luta por Direitos }\end{array}$ \\
\hline 2014 & Educação Popular & $\begin{array}{ll}\text { Carlos } & \text { Eduardo } \\
\text { Moreira } & \end{array}$ & $\begin{array}{l}\text { A Educação Popular e a Construção de } \\
\text { Políticas Públicas em Educação: Entre o } \\
\text { personalismo político e a participação } \\
\text { cidadão }\end{array}$ \\
\hline 2014 & Educação Popular & Maria Teresa Muraca & $\begin{array}{l}\text { Método e metodologia entre pedagogia } \\
\text { popular e feminismo }\end{array}$ \\
\hline 2014 & Movimentos Sociais & Luís Antonio Groppo & $\begin{array}{l}\text { A gênese do campo das práticas } \\
\text { socioeducativas no Brasil: Educação } \\
\text { popular, educação formal e pedagogia } \\
\text { social }\end{array}$ \\
\hline 2013 & $\begin{array}{l}\text { Gênero, Sexualidade e } \\
\text { Educação }\end{array}$ & $\begin{array}{l}\text { Maria Simone Vione } \\
\text { Scwengber }\end{array}$ & $\begin{array}{l}\text { As imagens e a educação generificada } \\
\text { dos corpos }\end{array}$ \\
\hline 2012 & $\begin{array}{l}\text { Gênero, Sexualidade e } \\
\text { Educação }\end{array}$ & $\begin{array}{l}\text { Karina Mirian da } \\
\text { Cruz Valenca Alves }\end{array}$ & $\begin{array}{l}\text { A subjetivação da mãe naturalista como } \\
\text { modelo: a maternidade como efeito das } \\
\text { pedagogias culturais }\end{array}$ \\
\hline 2011 & Educação Popular & $\begin{array}{l}\text { Fabiana Rodrigues } \\
\text { de Sousa e Maria } \\
\text { Waldenez de Oliveira }\end{array}$ & $\begin{array}{l}\text { Contribuições da educação popular e } \\
\text { fenomenologia para a pesquisa em } \\
\text { educação realizada com prostitutas }\end{array}$ \\
\hline 2011 & $\begin{array}{l}\text { Gênero, Sexualidade e } \\
\text { Educação }\end{array}$ & $\begin{array}{l}\text { Sandra dos Santos } \\
\text { Andrade }\end{array}$ & $\begin{array}{l}\text { Juventudes e processos de escolarização: } \\
\text { articulações entre trabalho e gênero }\end{array}$ \\
\hline 2011 & $\begin{array}{l}\text { Gênero, Sexualidade e } \\
\text { Educação }\end{array}$ & $\begin{array}{l}\text { Elenita Pinheiro de } \\
\text { Queiroz Silva }\end{array}$ & Tecendo percursos para pensar o corpo \\
\hline 2010 & $\begin{array}{l}\text { Gênero, Sexualidade e } \\
\text { Educação }\end{array}$ & $\begin{array}{l}\text { Roney } \\
\text { Castro e A Anderson de } \\
\text { Ferrari }\end{array}$ & $\begin{array}{l}\text { "Nossa! Eu nunca tinha parado pra } \\
\text { pensar nisso!" }\end{array}$ \\
\hline
\end{tabular}

Fonte: BARROCA, 2016

As pesquisas de Castro e Ferrari (2010) e Andrade (2011) foram selecionadas por apresentarem diferentes formas com as quais as identidades e manifestações de gênero e sexualidade são invisibilizadas no contexto da educação formal. Os trabalhos de Sousa (2014), Alves (2012) e Sousa e Oliveira (2011) foram consultados para trabalhar o conceito de intersecionalidade dentro do movimento. Muraca (2014), Moreira (2014) e Groppo (2014) possibilitam maior entendimento sobre as pedagogias presentes em movimentos feministas e atuações políticas nestes campos. Já Scwengber (2013) e Silva (2011) tecem pesquisas para a compreensão do conceito de os usos do corpo como instrumentos políticos. 
Ainda dentro da busca em fóruns de socialização de pesquisa que poderiam me auxiliar no levantamento bibliográfico, optei por uma busca nos anais de 2015 do Seminário Internacional Fazendo Gênero (Quadro 2), devido à sua grande visibilidade e importância nas questões que se propõe a discutir ${ }^{6}$. Das pesquisas apresentadas, selecionei 38 trabalhos. Após a leitura dos resumos, 11 trabalhos foram escolhidos.

\section{Quadro 2: Levantamento de trabalhos do Fazendo Gênero}

\begin{tabular}{l|l}
\hline \multicolumn{1}{c|}{ Autor } & \multicolumn{1}{c}{ Título do Trabalho } \\
\hline Tyara Veriato Chaves & Marcha das Vadias. Corpo, sujeito e ideologia. \\
\hline Rafaela Cyrino & $\begin{array}{l}\text { A categorização do masculino e do feminino e a ideia de } \\
\text { determinismo cultural: uma crítica epistemológica aos usos } \\
\text { normativos do gênero. }\end{array}$ \\
\hline $\begin{array}{l}\text { Raquel Costa Goldfarb, } \\
\text { Luzinete Simões Minella e } \\
\text { Mara Coelho de Souza Lago }\end{array}$ & $\begin{array}{l}\text { Marcha das Vadias na Paraíba: Sororidades, Performances e } \\
\text { Linguagem. }\end{array}$ \\
\hline $\begin{array}{l}\text { Telma Gurgel e Janaiky } \\
\text { Almeida }\end{array}$ & $\begin{array}{l}\text { Feminismo e as jovens feministas: Desafios programáticos e } \\
\text { organizativos. }\end{array}$ \\
\hline Lilam Litsuko Huzioka & $\begin{array}{l}\text { Conscientização contra a opressão de gênero: mulheres } \\
\text { populares e os desafios nas margens do sistema mundo } \\
\text { moderno/colonial. }\end{array}$ \\
\hline $\begin{array}{l}\text { Júlia Glaciela da Silva } \\
\text { Oliveira }\end{array}$ & $\begin{array}{l}\text { Intervenções estético-urbanas: Novas políticas dos } \\
\text { feminismos latino americanos }\end{array}$ \\
\hline Gabriela Miranda Marques & $\begin{array}{l}\text { Feministas libertárias: Práticas contemporâneas de } \\
\text { resistência }\end{array}$ \\
\hline Janaina de Araujo Morais & $\begin{array}{l}\text { Quem são essas vadias? Uma análise teórico-empírica sobre } \\
\text { o "sujeito político" da Marcha das Vadias do Rio de Janeiro }\end{array}$ \\
\hline $\begin{array}{l}\text { Carla Rodrigues e Maria } \\
\text { Luiza Heilborn }\end{array}$ & $\begin{array}{l}\text { Entre mulheres nômades: reflexões sobre o "sujeito } \\
\text { feminista" e o diálogo entre diferentes na Marcha das Vadias } \\
\text { - DF } \\
\text { Oliveira Saads e Líbia Rancimento }\end{array}$ \\
\hline
\end{tabular}

Fonte: Barroca, 2016

Os trabalhos de Morais (2013), Saads e Nascimento (2013), Oliveira (2013), Goldfarb, Minella e Lago (2013) e Chaves (2013) abordam diretamente sobre o sujeito político do movimento Marcha das Vadias e outras características do movimento em sua edição no Rio de Janeiro e em outros estados brasileiros. Já o artigo de Oliveira (2013) faz uma síntese sobre a luta feminista ao longo da história. Marques (2013) fornece elementos para melhor compreensão do anarco-

6 Outros anos não foram englobados nesta etapa de devido ao fato de que muitos trabalhos são publicados na Revista Estudos Feministas, que também foi alvo de pesquisa. 
feminismo. Este trabalho foi selecionado devido ao fato de que uma das entrevistadas se identifica com alguns elementos de atuação desta vertente de luta dentro da Marcha das Vadias RJ 2015. Os trabalhos de Rodrigues e Heilborn (2013) e Cyrino (2013) contribuem nas recentes discussões sobre o conceito de gênero e aprofundam a forma como tal conceito é definido por Scott (1990). Segui a seleção optando também pelo trabalho de Huzioka (2013) por abordar sobre as tensões as quais a luta feminista encontra devido à sua diversidade, adotando assim a perspectiva de feminismos.

Quadro 3: Levantamento de trabalhos em revistas acadêmicas

\begin{tabular}{l|l|l|l|ll}
\hline Ano & Periódico & $\begin{array}{c}\text { Área de } \\
\text { Conhecimento }\end{array}$ & \multicolumn{1}{|c|}{ Autor } & \multicolumn{2}{|c}{ Título do Trabalho } \\
\hline 2011 & Em pauta & Serviço Social & $\begin{array}{l}\text { Carla Cristina } \\
\text { Lima de Almeida }\end{array}$ & $\begin{array}{l}\text { Corpo e Gênero: Articulando um } \\
\text { debate }\end{array}$ \\
\hline 2014 & $\begin{array}{l}\text { Cadernos } \\
\text { Pagu }\end{array}$ & Feminismo & Sonia E. Alvarez & $\begin{array}{l}\text { Para além da sociedade civil: } \\
\text { reflexões sobre o campo feminista }\end{array}$ \\
\hline 2005 & $\begin{array}{l}\text { Revista } \\
\text { Estudos } \\
\text { Feministas }\end{array}$ & Feminismo & $\begin{array}{l}\text { Guacira Louro, } \\
\text { Jane Neckel e } \\
\text { Silvana Goellner }\end{array}$ & $\begin{array}{l}\text { Corpo, Gênero e Sexualidade: } \\
\text { Discussões }\end{array}$ \\
\hline 2007 & $\begin{array}{l}\text { Educação } \\
\text { e } \\
\text { Sociedade }\end{array}$ & Educação & $\begin{array}{l}\text { Célia Regina } \\
\text { Vendramini, }\end{array}$ & Pesquisa e movimentos sociais \\
\hline
\end{tabular}

Fonte: Barroca, 2016.

É importante ressaltar que todos os periódicos selecionados para a busca estão disponíveis online e possuem conceito A1 ou A2, segundo o Qualis Periódicos da Capes. As palavras-chave utilizadas foram as mesmas para todas as opções de busca.

Na seleção de trabalhos em periódicos (Quadro 3), busquei publicações que buscam promover discussões dentro do âmbito da Educação, inicialmente. Como forma de complementar, percorri dois periódicos da área de Serviço Social e outros que buscam promover especificamente uma discussão sobre feminismo. Todas as variações de buscadores estabelecidos foram tentadas a fim de possibilitar o máximo de registros que relacionasse, ao menos, duas categorias centrais para a pesquisa.

As revistas referentes à área de educação foram: Educação \& Sociedade e Cadernos de Pesquisa. Ambas possuem avaliação máxima (A1), segundo os critérios da área de Educação da Capes. A busca na Educação \& Sociedade resultou em três trabalhos, dentre os quais foi selecionado o trabalho de 
Vendramini (2007) que aborda sobre pesquisa em movimentos sociais. Na revista Cadernos de Pesquisa, não obtive nenhum resultado.

Os periódicos selecionados que buscam promover um debate sobre o feminismo e as questões relativas a gênero para esta etapa foram Cadernos Pagu e Revista Estudos Feministas. Foram escolhidos devido ao fato de que possuem grande relevância como fonte para estudos desta temática. No primeiro periódico, encontrei o artigo de Alvarez (2014) que traz reflexões sobre o movimento feminista que auxiliam no entendimento das novas formas de militância. $\mathrm{Na}$ Revista Estudos Feministas, os trabalhos localizados não possuíam contribuições diretas para meu objeto de pesquisa.

E, por fim, buscando fontes em áreas afins, que poderiam promover a discussão de assuntos relativos à temática me debrucei em revistas na área de Ciências Sociais e Serviço Social. Após percorrer os periódicos que atendiam aos critérios estabelecidos na área de Ciências Sociais, não obtive resultados relacionados à minha pesquisa. Partindo para a segunda grande área de conhecimento, realizei uma busca nos periódicos Serviço Social \& Sociedade e Em Pauta. No primeiro periódico, não encontrei nenhum trabalho que cumprisse os critérios de busca estabelecidos. Já no periódico Em Pauta, localizei quatro artigos, dentre os quais somente um foi selecionado. O trabalho de Almeida (2011) apresenta reflexões sobre os conceitos e corpo e sexualidade e as relações entre eles.

Na seleção realizada no Banco de Teses e Dissertações da Capes, as palavras-chave foram repetidas. Selecionei para leitura uma dissertação e duas teses por cumprirem os critérios de busca e apresentarem um diálogo possível com minha pesquisa.

A dissertação de Oliveira (2007) foi desenvolvida através do Programa de Pós Graduação em Educação da Universidade Federal da Bahia. A pesquisa busca evidenciar a pedagogia presente no Movimento Sem Terra e as relações de gênero entre os militantes. No entanto, após entrada no campo, pude perceber que tal trabalho não possuía um diálogo direto com minha pesquisa.

Outro trabalho selecionado foi a tese de doutorado do Departamento do Programa de Pós-Graduação em Educação da PUC-Rio, Russo (2011). A pesquisa busca apresentar as relações desenvolvidas entre as instituições sociais e a escola. A autora objetiva perceber se estas relações podem ser consideradas mecanismos 
de resistências à atuação neoliberal do sistema político e econômico nacional. E, por fim, a tese de Mesquita (2006) do Programa de Pós-Graduação em Psicologia Social da PUC-SP, foi adicionada à bibliografia deste trabalho por apresentar discussões que auxiliam na caracterização desses novos movimentos sociais.

É importante destacar que a seleção inicial dos trabalhos foi feita antes da entrada no campo. Após a mesma, retornei às pesquisas e percebi que alguns dos textos levantados não ofereciam um diálogo possível com as experiências vivenciadas e observadas na pesquisa. Assim, elas foram fundamentais para a compreensão da temática, mas nem todas foram diretamente incorporadas na análise dos dados. Após a entrada no campo e conversa com uma pesquisadora da área me foi sugerida uma nova busca com a finalidade de buscar artigos recentes sobre o tema. Foi realizada, então, na base de dados SciELO, um novo levantamento com as palavras chaves (i) Marcha das Vadias e (ii) Movimentos Feministas com o intuito de buscar trabalhos que trabalhassem a temática de forma mais específica. A partir desta busca os trabalhos de Andrade (2015), Mesquita (2003, 2006, 2008), Dutra e Nunes (2015) e Mattos (2014) foram acrescentados à discussão.

\section{2. Questões de pesquisa ou perguntas às fronteiras}

A partir das análises dos resultados encontrados no levantamento bibliográfico, das discussões nos referenciais teóricos e da ida inicial ao campo, formulei as questões norteadoras da pesquisa. A definição da temática e o reconhecimento que vinha fazendo das pesquisas realizadas nestas fronteiras entre educação, movimentos sociais e questões de gênero.

Assim, foram formuladas as seguintes questões centrais:

- Quais são e como se dão as práticas pedagógicas da Marcha das Vadias do Rio de Janeiro de 2015?

- Como se aprende a ser "vadia", ou seja, como são formadas as militantes da Marcha das Vadias RJ 2015?

As questões centrais se desdobraram em questões secundárias que me ajudaram a direcionar as leituras e a construção dos dados. São elas: 
- Como são as práticas pedagógicas existentes dentro de um movimento feminista?

- Como o processo de ensino e aprendizagem é compreendido?

- Que informações, conhecimentos, processos, habilidades e competências estão presentes neste processo pedagógico?

- Por se tratar de um movimento feminista, as práticas educativas estão pensadas a partir das questões de gêneros? As relações de gêneros estão presentes nas práticas pedagógicas? Como?

Estas foram consideradas questões iniciais e norteadoras, devido ao fato de que, ao longo do processo de pesquisa, modificaram seu foco devido ao caráter dinâmico do campo. Outra ponderação importante a ser feita diz respeito ao uso do termo "movimentos feministas", num primeiro momento. Com a entrada no campo e aumento gradativo de leituras e discussões percebi que cada movimento feminista é único e que atua de diferente forma. A Marcha das Vadias do Rio de Janeiro em 2015, por exemplo, reivindica-se como um movimento transfeminista interseccional $^{7}$ e apresenta formas diferentes de atuação em relação a outros movimentos feministas do mesmo espaço geográfico e mesma temporalidade.

\section{3.}

\section{Objetivos ou os alvos na fronteira}

A fim de cumprir as questões de pesquisa, foram traçados alguns objetivos, que, num campo fronteiriço como o que adentramos, funcionou como alvos que deveriam ser perseguidos. São eles:

- Identificar as práticas pedagógicas existentes na Marcha das Vadias do Rio de Janeiro, em 2015;

7 A Interseccionalidade aponta que as teorias sobre o movimento feminista não deve considerar trabalhar de maneira isolada com a perspectiva de gênero, como se todas as mulheres sofressem da mesma forma os diferentes tipos de opressões. Além do gênero, categorias como raça, etnia e/ou classe social devem ser consideradas. Assim, por exemplo, uma mulher branca de classe média sofre um tipo de opressão muito distinto de uma mulher negra das classes populares. Isto será explicitado no Capítulo 4. 
- Reconhecer quais são os conceitos chaves para a formação de uma identidade coletiva e individual no movimento da Marcha das Vadias RJ 2015;

- Refletir sobre as temáticas relativas a gênero e sexualidade adotadas pelo movimento Marcha das Vadias RJ 2015 e sua importância para a formação educativa do próprio coletivo;

- Entender qual é o destaque dado às discussões sobre relações de gênero que ocorrem dentro destas práticas pedagógicas.

\section{4.}

Opções metodológicas ou sobre como se movimentar nas fronteiras

Como premissa metodológica, explicito que esta pesquisa se configura no campo das análises qualitativas. A pesquisa se desenvolveu a partir de um estudo de caso dentro da Marcha das Vadias do Rio de Janeiro, edição de 2015. Tal opção se deu pelos seguintes motivos: o primeiro deles diz respeito à criação e atuação recente do movimento, o que possibilitou maior possibilidade de contribuição de minha pesquisa para o diálogo com as que estão sendo feitas até o presente momento; a segunda motivação diz respeito a uma tentativa de amplitude que o movimento possui, visto que atua defendendo diversas bandeiras; em terceiro, a grande visibilidade que o movimento vem constituindo na luta contra a opressão por meio de marchas públicas, englobando também em seu manifesto a luta das mulheres cis $^{8}$, trans e negras, o que possibilitou maiores números de casos a serem utilizados como fonte no trabalho de campo; em quarto lugar, o movimento é um dos poucos, senão o único na cidade do Rio de Janeiro, que se propõe a dialogar e defender causas de prostitutas, buscando, dentre outras bandeiras, a regulamentação da profissão; e, por fim, o movimento já possui uma estrutura organizada, com reuniões frequentes e abertas, o que facilitou a minha entrada no campo, a fim de entender os processos de aprendizagens que ali ocorrem.

$8 \mathrm{O}$ termo cis são pessoas cujo gênero está em conformidade como o gênero que lhe é designado no seu nascimento. $\mathrm{O}$ termo mulher cis se aplica quando uma mulher nasce com sexo biológico de fêmea (culturalmente conhecido como feminino) e apresenta um comportamento de gênero esperado socialmente para seu sexo, isto é, um comportamento de gênero feminino. $\mathrm{O}$ termo cis também pode ser aplicado para o homem. 
Os estudos de caso, uma das opções metodológicas deste trabalho, não intencionam a generalização de pesquisas sobre uma determinada temática. Nesta perspectiva, busco contribuir para o enriquecimento da relação entre educação, movimentos sociais e questões de gêneros, a partir da inserção num movimento social específico, a "Marcha das Vadias do Rio de Janeiro de 2015".

Assim, um estudo de caso se fez necessário para que a interpretação do contexto possa ocorrer de forma completa e por meio de inter-relações, como explicitado por Oliveira, Fonseca e Santos (2010). O resultado esperado nesta pesquisa não tem a intenção de ser apresentado como uma regra estipulada como geral, mas sim como uma possibilidade de que certas práticas pedagógicas analisadas na pesquisa possam ser evidenciadas e discutidas. O risco, então, de que tal pesquisa tenha a pretensão de generalizar conceitos e vivências, alertado por Gil (2002), está considerado nesta pesquisa. A intenção não é a de generalizações, mas sim a compreensão de que a partir de um caso específico seja possível uma análise de potencialidades e fragilidades do campo. Compreendo o movimento feminista como difuso e dinâmico. Seria improdutivo, portanto, a tentativa de criação de padronizações universalizantes.

A adoção da perspectiva de pesquisa participante (DEMO, 2008) tornou-se fundamental para a compreensão da dinâmica a qual fui apresentada. Devido ao fato de que a Marcha das Vadias RJ 2015 se posiciona ao lado de pessoas marginalizadas pela diferença e subalternizadas historicamente, o posicionamento de construir o movimento enquanto a pesquisa se fez possível. Este tipo de pesquisa torna-se mais complexa do que a pesquisa-ação, pois exige conhecimento e participação (DEMO, 2008). Além disso, é necessário um comprometimento político com o campo, o que se tornou uma consequência de um tema de pesquisa que nasceu de minha trajetória acadêmica e militante.

Pesquisa participante produz conhecimento politicamente engajado. Não despreza a metodologia científica em nenhum momento no sentido dos rigores metodológicos, controle intersubjetivo, discutibilidade aberta e irrestrita, mas acrescenta o compromisso com mudanças concretas, em particular voltadas para os marginalizados (DEMO, 2008, p. 8).

A possibilidade de que minha aceitação enquanto pesquisadora estaria condicionada à minha participação na construção da Marcha das Vadias do ano de 2015 já havia se apresentado por meio de literaturas sobre o campo (MORAIS, 2013) e também por meio de uma conversa prévia com uma das lideranças da 
Marcha das Vadias do Rio de Janeiro, que posteriormente foi entrevistada. Demo (2008) defende que a pesquisa participante não busca somente uma devolução dos trabalhos, dos dados e das análises para o campo, mas exige do pesquisador que participe de projeto comunitário, "ainda que não seja comunitário" (DEMO, 2008, p. 43), como é o caso da Marcha das Vadias RJ 2015. Assim, a identificação política com o campo se mostrou fundamental em minha pesquisa.

A participação não envolve uma atitude do cientista para conhecer melhor a cultura que pesquisa. Ela determina um compromisso que subordina o próprio sujeito científico de pesquisa ao projeto político dos grupos populares cuja situação de classe, cultura ou história se quer conhecer porque se quer agir. (BRANDÃO, 1982, p.12 apud DEMO, 2008, p. 10)

Buscando entender a participação e a militância na Marcha das Vadias RJ 2015, observações e entrevistas semiestruturadas foram adotadas para a coleta de dados. Após o primeiro contato com o movimento, realizei uma observação participante (ZANTEN, 2004), na qual estive imersa no campo e na construção da Marcha das Vadias RJ 2015. Assim, com o aval do meu orientador acadêmico, decidi participar ativamente da construção da Marcha das Vadias RJ 2015, como pesquisadora e militante. Tento em vista minha trajetória, posso afirmar que não se tratou de encenar uma militância inexistente diante de um movimento real, a fim de conseguir os dados desejados, mas de uma inserção como militante que pesquisa e como pesquisadora que milita.

Após o primeiro contato foi possível vislumbrar, aos poucos, a dinâmica do movimento, que em 2015 se estruturou por meio de reuniões, rodas de conversa, oficina de construção de instrumentos, um encontro festivo chamado de "isoporzinho" e na culminância do movimento Marcha das Vadias em si, realizada no dia 14 de novembro. Além desses espaços, ocorreram dois encontros nos quais militantes da Marcha das Vadias RJ 2015 foram convidadas: um na UERJ, onde a mesa foi dividida com outras feministas e outros movimentos e outro no Colégio de Aplicação Fernandes Figueira (CAp-UERJ) no qual uma das

9 Isoporzinho corresponde ao nome dado pelas militantes da Marcha das Vadias e também por outros movimentos sociais ao ato festivo que consiste em comercializar bebida alcoólica para obter fonte de renda para a organização do próprio movimento ou outras motivações pontuais e específicas. O nome é atribuído ao fato de que neste evento há uma caixa de isopor para que as bebidas sejam mantidas em temperatura adequada para venda. 
militantes da Marcha das Vadias RJ 2015 esteve presente conversando com adolescentes sobre o tema "consentimento" 10 .

Seguindo esta dinâmica, os dados da pesquisa se estruturam a partir da observação de doze reuniões, realizadas entre maio e dezembro de 2015. O total de reuniões em 2015 foram catorze. No entanto, não pude estar presente em duas, mas acompanhei o processo por meio das atas e das atualizações nas reuniões seguintes. Além disso, as análises se embasaram em diários de campo que eram feitos com anotações rápidas e diretas durante os encontros que eram ampliadas logo após a edição de cada reunião. As anotações seguiam o roteiro de observação (Apêndice 6.4), elaborado antes do primeiro contato com o campo.

A partir da observação das reuniões e das anotações no diário de campo, pude escolher quais mulheres eu iria entrevistar e partir para a segunda etapa da coleta de dados. Assim, foram realizadas dez entrevistas, seguindo as orientações de entrevistas semiestruturadas. O roteiro (Apêndice 6.5) das mesmas foi confeccionado após a observação de algumas reuniões.

A opção pela entrevista semiestruturada buscou a construção de um conhecimento junto com as entrevistadas, respeitando a participação ativa das mesmas no processo. Szymanski (2011) defende que a participação das entrevistadas nunca é passiva, isto é, elas possuem total autonomia na construção conjunta dos dados, visto que interferem diretamente na produção dos mesmos. Estou certa de que a minha identificação como militante do movimento feminista apresentou-se fundamental para a entrada no campo e aceitação das entrevistas, bem como para a melhor interação com as entrevistadas e com o campo, que buscava se formar a partir de uma relação horizontal de poder e de conhecimento. Por meio de uma escuta atenta e respeitosa, busquei perceber a relação destas militantes umas com as outras e as suas escolhas para uma formação coletiva de identidade do movimento por meio de suas práticas educacionais.

10 A ideia de consentimento parte da premissa de que qualquer tipo de contato físico precisa partir de permissão dada em plenas condições de reflexão sobre o assunto. Por exemplo, mulheres sob efeito de álcool ou outras drogas que alteram a percepção da realidade não estão em plenas condições de tomar as mesmas decisões que tomariam sóbrias. Exemplificando e explicando melhor, em nossa sociedade quando uma mulher diz "não!" esta palavra é entendida como "charme", como se ela estivesse "se fazendo de difícil" para um homem. A partir de conversas com uma das integrantes entendo que consentir com algo é dar permissão para que isso aconteça. Para isso, as pessoas devem exercer plena capacidade de tomar tal decisão, isto é, não podem estar com sua percepção de realidade alteradas por qualquer substância, nem devem estar sob qualquer tipo de pressão coercitiva. 
As entrevistadas foram selecionadas por meio de dois critérios: todas as militantes que construíram a Marcha das Vadias do Rio de Janeiro de 2015 e as demais foram indicações de uma das entrevistadas seguindo o critério de que participaram de mais de uma edição do movimento Marcha das Vadias do Rio de Janeiro até o ano de 2015. Nenhuma entrevista apresentou dificuldade em ser agendada e foram feitas em diferentes locais: casa das entrevistadas, uma mesa de bar, uma praça próxima à casa de uma das entrevistadas, Biblioteca do Centro Cultural do Banco do Brasil, uma cafeteria próxima à casa de uma das entrevistadas, UERJ e Casa Nuvem. Todas as entrevistadas preencheram o Termo de Consentimento Livre e Esclarecido (TCLE - Apêndice 6.1) e a Ficha de Cadastro (Apêndice 6.3), que solicitava algumas informações sobre a participação na militância feminista, dados pessoais e formação escolar. As dez entrevistas foram gravadas, sendo sete delas transcritas por mim e as outras três por dois membros do grupo de pesquisa do qual participo. Todas as entrevistas foram revisadas por mim.

Por meio da transcrição e revisão das entrevistas, uma prévia leitura dos dados a serem trabalhados foi realizada, o que facilitou a escolha dos temas chave desta pesquisa. Outra vantagem do processo de transcrição e revisão das entrevistas é poder rememorar o que foi falado pelas entrevistadas percebendo quais assuntos lhes comoviam, alegravam ou as deixavam mais resistentes.

Além das observações e entrevistas, houve intenso debate por meio da lista de e-mail criada para a construção da Marcha das Vadias RJ 2015 e também a partir da criação de um bate papo do Facebook, no qual as pessoas eram adicionadas e se retiravam ao longo do processo. Tais recursos buscavam dinamizar a comunicação das integrantes do grupo e me foram úteis para a construção dos dados. Relatos das presentes nos eventos nos quais a Marcha das Vadias RJ 2015 foi convidada e minha participação nas rodas de conversas também conformam o escopo de dados desta pesquisa.

Como procedimento de análise, o software para análises qualitativas Atlas Ti versão 7.5 foi utilizado. Após a leitura flutuante das entrevistas transcritas e da escolha dos três temas-chave de análise, as categorizações de todas as falas tiveram como foco dar sustentação às argumentações teóricas escolhidas antes e durante a coleta dos dados. A leitura e criação de códigos das falas das entrevistadas foram feitas a partir da escolha destes três grandes temas, da leitura 
dos referenciais teóricos e da caracterização do movimento oriunda da vivência nele. Assim, os códigos criados possuíram o intuito de relacionar a fala das entrevistadas com os referenciais de análise (CASTELLS, 2013, 2015; GOHN, 2001a, 2011b, 2012, 2014; HOOKS, 2013; MESQUITA, 2003, 2006, 2008) e de localizar formas de evidenciar as impressões das próprias entrevistadas sobre o movimento e sobre os seus aprendizados. A seleção de falas e palavras principais deu origem a criação de 33 códigos (Apêndice 6.6) que auxiliaram na análise dos dados.

\section{5 .}

\section{Estrutura da dissertação ou sobre um novo mapa para a fronteira}

Destaco que toda a escrita da dissertação é um compromisso ético com o campo (Anexo 7.1) e com os pressupostos teóricos e metodológicos que estruturam a pesquisa em Educação no Brasil. Toda a pesquisa foi construída juntamente com o campo e isso refletiu diretamente na organização estrutural dos capítulos subsequentes.

Nesse sentido, o segundo capítulo apresenta a Marcha das Vadias do Rio de Janeiro e sua edição do ano de 2015 e descreve minha entrada e primeiras impressões do movimento. Alguns esclarecimentos a respeito do nome do movimento e como ele será referenciado nesta pesquisa são necessários, estando, portanto, a seguir.

O movimento Marcha das Vadias teve sua primeira edição em 2011 em Toronto no Canadá. Desta edição, milhares de mulheres de diferentes partes do mundo organizaram reproduções locais do movimento (capítulo 2). Uma destas foi a do Rio de Janeiro, aqui nomeada Marcha das Vadias RJ. No entanto, uma das características desta edição é o fato de que a cada ano o movimento se organiza de uma forma e com pessoas diferentes, sendo então nomeado Marcha das Vadias RJ 2011, Marcha das Vadias RJ 2012 e assim consecutivamente. Esta investigação possui como eixo central do tema de pesquisa compreender as pedagogias presentes na Marcha das Vadias RJ 2015. Outra utilização desta pesquisa se refere à culminância da organização do movimento Marcha das Vadias e de suas diferentes edições. O termo marcha, em minúscula, refere-se à caminhada das mulheres em data pré-definida pelas edições do movimento na 
qual elas evidenciam por meio de palavras de ordem, manifestações e performances suas bandeiras de luta.

Feitos estes esclarecimentos sobre os termos, apresentarei brevemente os capítulos seguintes. O terceiro, o quarto e o quinto capítulos são algumas das análises possíveis sobre as temáticas que envolvem o campo.

O primeiro tema-chave (capítulo 3) fala sobre a importância da temática de gênero e sexualidade para o movimento, bem como apresenta a importância que o corpo tem para as militantes, como fonte de empoderamento, militância e ocupação das ruas. A Marcha das Vadias RJ 2015 apresenta importantes pontos de subversão de aspectos culturais que moldam e criam expectativas sobre corpos femininos e sobre os corpos tidos como distantes dos padrões de "normalidade".

O segundo tema-chave (capítulo 4) tem como ponto de partida relacionar a questão do tratamento com a diferença com a perspectiva intersecional do movimento. As dificuldades da militância horizontal no movimento são abordadas neste tema. O capítulo apresenta algumas tensões e diálogos possíveis dentro do movimento, tendo como central tratar de questões sobre a percepção e participação do feminismo negro no movimento e de questões sobre o diálogo que o movimento possui com as pessoas trans e as prostitutas. Os conceitos e a importância da interseccionalidade também passam pela imersão e tomada para si da luta de pessoas com deficiência física.

Por fim, o capítulo 5 aborda o terceiro tema-chave que surge a partir das falas das entrevistadas nas quais explicitam quais são os espaços educativos do movimento e de que forma elas acreditam que a militância neste espaço possibilita a formação de outras pedagogias para si e para outras pessoas próximas ao movimento. A socialização e a organização do movimento em redes também é um importante meio de formação pedagógica, conforme analisado neste capítulo. 


\section{2 \\ Da Hierarquização à leveza: de movimentos sociais à "micareta política"}

Movimentos Sociais, segundo Gohn (2011), remete-nos à busca pela concretização de ações coletivas que possuem um caráter sociopolítico e cultural. Eles podem, ainda, apresentar inúmeras formas de organização e de atuação. Essas particularidades sugerem diferentes demandas dentro dos movimentos sociais e ocasionam a formação de diferentes grupos que possuem identidade própria, mas que não estão impedidos de se relacionar e de formar uma frente de atuação conjunta em algumas manifestações ou reivindicações que se dão no âmbito público.

A busca de maior entendimento da dinâmica de movimentos sociais parte da premissa de que este espaço possibilita novas formas de vivência e exercício da cidadania. Gohn (2012) alerta que o conceito de cidadania, nas sociedades ocidentais, aparece em conjunto com o liberalismo e atrelado à noção de direito a ter direitos.

A propriedade, neste contexto, surge como um direito supremo servindo para diferenciar o cidadão da classe trabalhadora. A posse possibilitava que as classes mais altas e com alto poder aquisitivo pudessem exercer direitos civis e políticos. A classe trabalhadora, nesta conjuntura, era considerada incapaz de ter ideias sublimes, incapaz de pensar (Gohn, 2012, p. 16).

Ainda segundo Gonh (2012), o século XVIII ampliou a noção de cidadania quando exigiu a conscientização do homem ${ }^{11}$ como sujeito histórico capaz de modificar a realidade. As desigualdades sociais passaram a ser vistas pelo prisma das diferenças de capacidade. À medida que o capitalismo se consolida, a noção de cidadania vai ganhando novas concepções e, no século XIX, o conceito se dirige a todos, a partir da defesa de inclusão das massas, dos trabalhadores. No entanto, a cidadania se apresentava muito mais como uma ferramenta de

11 Aqui o termo foi utilizado no masculino de forma proposital, pois às mulheres estavam alijadas do poder de exercício político e civil nesta época. 
dominação e domesticação do que o acesso ao exercício pleno dos direitos civis e políticos.

No século XX, enfatiza-se o papel do Estado que passa a regulamentar os direitos dos cidadãos, agora mais ampliados a todas as classes. No entanto, a questão passa a ser vista com muito mais ênfases nos deveres e nem tanto nos direitos. As instituições modernas, tais como a escola e a empresa, passam a ser representadas como uma grande comunidade com amplo poder social. É retomada a ideia de que o cidadão civilizado é aquele que saiu do estágio da barbárie. Nesta perspectiva, a educação passa a ser utilizada para a formatação de uma concepção idealizada de convivência social de forma mais intensa. Os movimentos sociais se estabelecem após e durante esta conjuntura, como uma "terceira acepção do conceito de cidadania" (Gohn, 2012, p. 20), elaborada a partir de diversos grupos organizados de diferentes camadas sociais, passando a defender uma cidadania coletiva.

Tratando destes ativismos na contemporaneidade, Mesquita (2006) aborda o estudo sobre movimentos sociais centrando-os como uma expressão da juventude. Mesquita (2006) afirma que nas décadas de 1960 e 1970, os estudos que relacionavam movimentos sociais e juventude centravam-se na categoria estudantil. $\mathrm{O}$ contexto de resistência às diversas ditaduras, presente também no cenário brasileiro, fomentava um tratamento teórico e panorâmico no qual a dimensão da participação política estava em destaque. Atualmente, a relação entre movimentos sociais e juventude é centrada em perspectivas que englobam aspectos de militância como parte da cultura e da sociabilidade entre jovens.

A literatura especializada sobre movimentos sociais (CASTELLS, 2013, 2015; GOHN, 2011a, 2011b, 2012, 2014; MESQUTA, 2003, 2006, 2008) aponta que os movimentos de juventude entendidos como clássicos, isto é, estudantis, pastorais sociais e associação partidária, não tem despertado muito interesse nos jovens devido à forma de organização na qual predomina uma forte hierarquia, centralização de decisões e maior demanda de seus participantes. Tal estruturação é resultado da intervenção de partidos políticos dentro desses movimentos que, no início de sua formação, buscavam uma perspectiva autônoma de militância (MESQUITA, 2006, p. 20).

A Marcha das Vadias do Rio de Janeiro 2015 é um movimento em que, cada vez mais, jovens fazem parte de sua construção e eclosão. Nas três últimas 
edições, visualmente constatou-se que a participação de mulheres que ainda estão na Educação Básica estão aderindo ao movimento. Assim, é importante considerar os fatores que tratam do interesse destas militantes. Outro ponto a ser considerado é que a temática da identidade está mais presente nos movimentos sociais. A defesa dos interesses das minorias, bem como a atuação destas na reivindicação do espaço público, político e sociocultural são mais predominantes tanto nos movimentos jovens clássicos, como também em outros. É importante partir desse pressuposto de análise para o estudo de ativismos contemporâneos que se materializam de formas diferenciadas.

A comparação geracional, portanto, realizada muitas vezes a partir da naturalização da imagem do jovem ligada a uma intervenção política - que não consegue ver as nuances e diferenças no que diz respeito a outras formas e estilos existente hoje mais atrapalha do que ajuda numa análise do contexto da participação juvenil atual. (MESQUITA, 2006, p. 30).

A juventude apresenta-se como ponto chave para análise da sociedade, visto que evidencia todas as contradições bem como os pontos de transformação da mesma (MESQUITA, 2006).

Em contraste com as sociedades estáticas ou em lenta mutação, as sociedades dinâmicas que querem dar uma nova saída, qualquer que seja sua fisionomia social ou política, confiarão mormente na cooperação da mocidade. Elas organizarão seus recursos vitais e os utilizarão para por abaixo a direção consagrada do desenvolvimento social. (MANNHEIN,1968, p. 72 apud MESQUITA, 2006, p.30).

Essa predominância da juventude e as novas dinamizações de militância também ocorrem nos movimentos feministas. Em alguns movimentos sociais contemporâneos, percebemos que a militância clássica e essa demanda por dinamicidade se misturam, enquanto que, em outros movimentos, estas novas formas de se posicionar e atuar perante as injustiças da sociedade são predominantes. Ainda sobre as novas formas de atuação política que almejam a mudança social, Castells (2015) afirma que os movimentos sociais foram e ainda continuam a ser as alavancas que movem mudanças sociais.

Geralmente se originam de uma crise nas condições de vida que torna insustentável a existência cotidiana para a maioria das pessoas. São induzidos por uma profunda desconfiança nas instituições políticas que administram a sociedade. A conjuminância de degradação das condições materiais de vida e crise de legitimidade dos governantes encarregados de conduzir os assuntos públicos leva as pessoas a tomar as coisas em suas próprias mãos, envolvendo-se na ação coletiva fora dos canais institucionais prescritos para defender suas demandas e, no final, mudar os governantes e até as regras que moldam suas vidas (CASTELLS, 2013, p. 161). 
A mudança social envolve atuações individuais e/ou coletivas e são motivadas e refreadas por emoções, nas quais, muitas vezes, a raiva é o gatilho e o medo o sentimento que desestabiliza e repreende o movimento. Este medo é superado a partir do sentimento de compartilhamento e identificação com outras pessoas em um processo de ação comunicativa que se mantém, por sua vez, pelo entusiasmo, responsável por reforçar a mobilização de cunho intencional (CASTELLS, 2013, p. 162).

Nesta pesquisa, a conceituação de movimentos sociais se refere ao seu entendimento sobre as formações de redes, que ocorrem nestes espaços e por conta da existência e mobilização deles. Castells (2013, p. 163) afirma que os movimentos sociais que surgiram no mundo nos últimos anos "são conectados em rede de múltiplas formas". Neste sentido, o uso das redes de comunicação da Internet e dos telefones móveis é essencial para uma formação de redes sociais online e off-line ${ }^{I 2}$, bem como a manutenção das redes internas dos próprios movimentos e a formação de redes com outros movimentos. Concomitante a este processo, formam-se redes com a mídia e também com o restante da sociedade. Mesmo que estes movimentos tenham o espaço urbano como base para suas atuações, não se restringem a ele, pois atuam também em todo o espaço virtual.

A discussão tratada por Castells (2013) é um dos pontos chaves (Capítulo 5) para compreender as formas de organização do movimento Marcha das Vadias e suas diferentes edições no Brasil e no mundo. Sendo uma destas, a edição do Rio de Janeiro de 2015, foco desta investigação. No entanto, para que o movimento possa ser mais detalhadamente caracterizado e explicado se faz necessário um pequeno histórico sobre os movimentos feministas em âmbito mundial e nacional, conforme veremos a seguir.

\section{1.}

\section{A militância das mulheres}

12 Redes sociais online referem-se às relações interpessoais e diálogos travados nas plataformas disponíveis na Internet. Redes sociais off-line são as relações interpessoais travadas fisicamente, isto é, presencialmente. 
Mesmo tendo objetivos comuns de lutar contra a opressão patriarcal ${ }^{13}$, os movimentos feministas apresentam diferentes correntes em todo o mundo. Atualmente, os movimentos feministas são pautados na busca da defesa da igualdade das relações de gênero. No entanto, nem sempre as reivindicações das mulheres possuíam essa característica. A luta das mulheres, para fins didáticos, poderia ser dividida em três momentos ou "ondas".

Há autores que utilizam o termo "ondas" para caracterizar as diferenças temporais, as motivações e as características de atuação do movimento feminista no Brasil e no mundo. No entanto, Gomes e Sorj (2014, p. 436) atentam que esta periodização do feminismo em ondas vem sendo contestada:

Em primeiro lugar, por que a metáfora de "onda" remete a um processo de constante substituição de feminismos, no qual o anterior se esvai e é sucedido por um novo, ignorando as linhas de continuidade entre eles.

Esta periodização das lutas afeta a teoria feminista, pois conforma a ideia de rupturas radicais, quando o movimento ainda possui reivindicações que não foram atendidas desde o seu surgimento de forma mais organizada. Assim, considero que a utilização do termo "ondas" pode homogeneizar a atuação de diversos movimentos feministas ao longo da história que não se encaixam nessas características fechadas, invisibilizando as disputas de poder e de luta que ainda ocorrem dentro dos movimentos feministas.

Em que pese às críticas de Gomes e Sorj (2014), apresentaremos a periodização a partir do conceito de "geração" e não de "ondas". A ideia de geração pode nos ajudar a situar as lutas feministas historicamente, sem considerar que há uma superação de uma etapa pela outra, mas apenas que há especificidades em cada período histórico.

Assim, temos que a primeira geração do feminismo, compreendida entre o final do século XIX e a Segunda Guerra Mundial, na qual as mulheres se organizavam em busca de direitos fundamentais, tais como voto, acesso a carreiras consideradas exclusivas aos homens e melhores condições de trabalho. É

13 Para Saffioti (2004), o patriarcado é uma condição histórica de dominação da mulher pelo homem baseada em diferentes culturas. No entanto, é mais forte na cultura ocidental. Referese à relação de poder que o homem/pai detinha sobre a vida das mulheres de sua família. Relação que, ao longo do tempo, foi se transformando e, embora, atualmente, o homem não detenha o poder jurídico sobre a vida da mulher na maioria dos países ocidentais, ele ainda detém muitas formas de submissão e opressão que são normatizadas, ensinadas e também evidenciadas na categoria de violências simbólicas ou diretas. 
importante destacar que, neste momento histórico, as mulheres brancas possuíram maior destaque e que as mulheres negras e suas condições de vida, trabalho, bem como o seu cotidiano e suas opressões ainda eram bastante invisibilizadas. Vale lembrar que, no caso brasileiro, no início do período retratado por esta primeira geração, ou seja, o final do século XIX, as mulheres negras haviam saído, a pouquíssimo tempo, da situação jurídica de propriedade dos senhores de escravo. O movimento feminista negro, no mundo e no Brasil, passou a ter maior destaque a partir da década de 1960, com a fundação, nos Estados Unidos, da National Black Feminist.

A segunda geração, anos de 1960 e 1970, marca a consolidação do feminismo como um movimento político a partir da busca por maior controle sobre o próprio corpo. A criação da pílula anticoncepcional é um marco deste momento histórico, visto que ofereceu uma possibilidade de escolha das mulheres sobre o momento de ser mãe, por exemplo. O surgimento do anticoncepcional potencializou a busca pelo prazer nas mulheres e abriu precedentes para o planejamento familiar. É importante ter em mente que essa escolha nem sempre foi respeitada.

A terceira geração, década de 1980, marca o início das contestações de feministas da homogeneidade que, até então, havia se mostrado frutífera e útil na luta política. A diversidade na formação de identidades entrou em campo e surgiu um momento de renovação teórica, tanto para o "feminismo branco" quanto para a luta das mulheres negras. O feminismo branco é o feminismo construído por uma maioria numérica de mulheres brancas.

É importante salientar, mais uma vez, que ainda hoje tais gerações se misturam. Estes marcos temporais são apenas para fins didáticos, pois a luta por participação política, controle do corpo e reconhecimento das identidades de gênero ainda persistem.

Tratando-se do caso brasileiro, o movimento feminista obteve maior visibilidade no contexto de luta contra a ditadura civil e militar instaurada em 1964, com o golpe ao governo de João Goulart. Isso não significa dizer que antes deste período não havia mulheres lutando pelos seus direitos. A conjuntura nacional coincidia com a segunda geração do movimento feminista em todo o mundo, no qual a luta por direitos igualitários, principalmente, no trabalho e na educação se fazia presente na maioria dos movimentos feministas. Além das 
bandeiras comuns da segunda geração de lutas feministas, o contexto ditatorial nacional motivou a entrada de mulheres na luta política que tomou conta do país.

As primeiras organizações feministas nacionais, por conta do contexto, foram forjadas no interior das organizações políticas de esquerda ou em associação direta com elas. Essas atuações e vivências possibilitaram a essas mulheres um espaço de aprendizagem no qual puderam compreender de forma mais ampla as condições de opressão as quais estavam subjugadas e condicionadas. Tais situações de opressão eram determinadas tanto pelo seu sexo biológico quanto também pela sua cor $^{14}$ e pelo seu papel no modo de produção capitalista.

Hoje, para perceber a diversidade de organização destes movimentos, a luta das mulheres pode ser vinculada a organizações partidárias, a movimentos autônomos em bairros e/ou comunidades marginalizadas no processo de ocupação e uso do espaço urbano, ao movimento estudantil das universidades e escolas da educação básica, mas também pode ser articulada e atuar de forma autônoma e auto-organizada. Na busca de não recorrer em generalizações de um movimento tão complexo, rico e dinâmico, organizado e fortalecido historicamente, optei, como já explicitado anteriormente, pela escolha de um movimento para o desenvolvimento desta pesquisa e que apresentarei, mais detalhadamente, a seguir.

\section{2. \\ O campo: a pesquisa como vivência}

A organização em redes, o movimento como espaço de socialização, a motivação por emoção, a forte presença da juventude e o uso de espaços urbanos e virtuais (CASTELLS, 2013, 2015; MESQUITA, 2003, 2006, 2008) são algumas

14 É importante destacar aqui que o movimento feminista negro se diferencia (e reivindica essa diferença) do movimento feminista organizado majoritariamente por mulheres brancas. Por exemplo, enquanto estas reivindicavam o direito ao acesso do mercado de trabalho, as mulheres negras já ocupavam este lugar como uma categoria subalterna. A motivação para esta categoria é oriunda das condições históricas nas quais os negros foram submetidos ao regime de trabalho forçado em nosso país. Neste contexto, as mulheres eram utilizadas como produto para satisfazer as necessidades sexuais, privadas e públicas da elite masculina branca e também para servir às mulheres brancas desta camada social. Com a assinatura da lei Áurea, os negros continuaram ocupando o espaço marginalizado das relações sociais e produtiva. As mulheres negras nunca deixaram de ocupar espaços precários de trabalho visto que sua sobrevivência e a de sua família dependiam dessa sua inserção. 
das características presentes, atualmente, na Marcha das Vadias do Rio de Janeiro, em especial na de 2015. Diferente da atuação dos movimentos sociais que, historicamente, atuaram em parceria com instituições partidárias de esquerda, a Marcha das Vadias RJ 2015 se propõe a ser um movimento em que a multiplicidade e o diverso substituíram o centralismo e, em certa medida, o formalismo na atuação social. Não podemos, no entanto, supor que as diversas Marchas das Vadias organizadas pelo mundo são as únicas com tais características, mas elas fazem parte de um contexto de surgimento de novas formas de protesto e de reivindicação em que os corpos dos excluídos passaram a ter visibilidade e autonomia. A atuação em redes (CASTELLS, 2013, 2015) auxilia na quebra de alguns paradigmas sociais e fortalece o movimento na medida em que possibilita diferentes formas de atuação e maior alcance.

Por serem uma rede de redes, eles podem dar-se o luxo de não ter um centro identificável, mas ainda assim garantir as funções de coordenação, e também de deliberação, pelo inter-relacionamento de múltiplos núcleos. Desse modo, não precisam de uma liderança formal de um centro de comando ou de controle, nem de uma organização vertical, para passar informações ou instruções. Essa estrutura descentralizada maximiza as chances de participação no movimento, já que ele é constituído de redes abertas, sem fronteiras definidas, sempre se reconfigurando segundo o nível do envolvimento da população em geral. (CASTELLS, 2013, p. 164).

Tendo em vista que esta pesquisa busca perceber as formações - humana, social e política - que movimentos feministas proporcionam. Ressalto meu posicionamento de que a criação da Marcha das Vadias RJ por si só já se configura como um aprendizado, tanto para o movimento feminista quanto para a sociedade patriarcal, sexista, machista, homofóbica, lesbofóbica e transfóbica. Tal afirmação parte da constatação histórica e que vem sendo cada vez mais publicizada e utilizada como fonte de pesquisa e militância da posição subalterna que as mulheres ocupam em nossa sociedade. A partir das transformações motivadas por outros movimentos sociais, incluindo principalmente os movimentos feministas, elas passaram a protagonizar suas bandeiras de luta das mais variadas formas. Assim, a Marcha das Vadias do Rio de Janeiro é uma possibilidade de um período histórico e também é protagonista deste tempo.

A grande visibilidade do movimento e o aumento de participantes evidenciam que as formas de atuação dos movimentos feministas sofreram alterações estruturais. Podemos caracterizar esse tipo de atuação como parte da terceira geração do feminismo. No entanto, é importante ressaltar que esse tipo de 
atuação é fruto também das próprias contradições vivenciadas pelos movimentos feministas que atuavam em espaços mistos ${ }^{15}$ de militância, mas que enfrentavam as dificuldades de se lidar com o grande número de identidades de mulheres. Além disso, esse panorama pode ser explicado pela adesão da juventude ao movimento, que busca formas menos rígidas de expressão de suas identidades, bem como de materialização de sua luta de mudança do mundo.

A Marcha das Vadias RJ e sua edição em 2015 representa apenas uma das diferentes maneiras de se lutar contra as desigualdades motivadas por diferenças de gêneros e sexualidades existentes em nossa sociedade. Mas também luta pela regulamentação da profissão de prostitutas, por maior liberdade sexual da mulher, pelo reconhecimento da igualdade de pessoas trans nos direitos civis, políticos e jurídicos e contra todos os tipos de opressões machistas e misóginas que atravancam a conquista da liberdade e de direitos em nossa sociedade.

\section{Quadro 4: Perfil das entrevistadas}

\begin{tabular}{c|c|c|c|c|c}
\hline Nome & Idade & Cor & Formação & $\begin{array}{c}\text { Primeira } \\
\text { Participação }\end{array}$ & $\begin{array}{c}\text { Outras } \\
\text { militâncias }\end{array}$ \\
\hline Antônia & 35 & Mestiça & Superior (completa) & 2012 & Sim \\
\hline Nathalia & 34 & Branca & Pós-graduação (cursando) & 2012 & Sim \\
\hline Cláudia & 33 & Branca & Pós-Graduação (cursando) & 2012 & Não \\
\hline Heloisa & 31 & Branca & Pós-Graduação (cursando) & 2011 & Nim \\
\hline Isa & 19 & Branca & Graduação (cursando) & 2013 & Sim \\
\hline Beatriz & 40 & Branca & Pós-Graduação & 2014 & Sim \\
\hline Manuela & 26 & Negra & Graduação (cursando) & 2012 & Não \\
\hline Millena & 25 & Branca & Pós-Graduação (cursando) & 2013 & Sim \\
\hline Virginia & 56 & Mistura de raças & Ensino Médio & 2011 & Sim \\
\hline Indianara & 44 & Vermelha & Não respondeu & 2011 & \\
\hline
\end{tabular}

Fonte: BARROCA, 2016

15 São espaços em que mulheres e homens atuam juntos. No entanto, há diversos relatos de experiências de machismo nestes espaços, vivenciadas inclusive por mim. Estas ocorrências motivam, cada vez mais, que as mulheres busquem outras formas autônomas de organização dando origem a diversos coletivos feministas em todo o mundo. 
Para melhor compreender o movimento e suas militantes, um perfil das entrevistadas foi traçado. O Quadro 4 apresenta os dados retirados da Ficha de Cadastro (Apêndice 6.2) preenchidas por todas as entrevistadas no momento das entrevistas.

Todas as entrevistadas foram selecionadas após observações e construção do movimento. O roteiro de entrevista semiestruturado foi construído após as observações iniciais sobre o campo. Das dez entrevistadas, cinco construíram a marcha de 2015. Destas, somente duas foram a quase todas as reuniões. As outras cinco construíram o movimento em anos anteriores e foram indicadas pelas primeiras entrevistadas.

Dentre as entrevistadas, há mulheres cis lésbicas, bissexuais, gênero fluido $^{16}$, uma transexual e também pessoas cis héteros. Os nomes de pesquisa foram escolhidos pelas próprias entrevistadas e a cor explicitada na tabela é fruto de auto identificação das mesmas. Duas das entrevistadas também tinham pesquisado e militado em edições anteriores.

Expostas essas considerações iniciais sobre o movimento e algumas de suas militantes, apresentarei um histórico da criação do movimento.

\section{3. A vontade das mulheres em marcha pelo mundo}

A primeira edição do movimento Marcha das Vadias (SlutWalk) ocorreu em Toronto, Canadá, em 2011. O caso que desencadeou o evento foi a fala de um policial durante uma palestra sobre segurança dentro do campus na Universidade de York, após a ocorrência de muitos casos de abusos sexuais. De acordo com o policial Michael Sanguinetti, uma das possibilidades de prevenção dos casos de abusos sexuais seria a mudança na maneira de se vestir das mulheres, isto é, elas não deveriam se vestir como sluts (vadias, putas), segundo sua concepção. Tal declaração gerou uma repercussão muito grande por parte das mulheres do campus que exteriorizaram a polêmica, visto que a declaração do policial tinha como premissa a culpabilização da vítima. O comentário foi interpretado como

16 Gênero fluido é uma nomenclatura que indica uma pessoa que não se identifica com o padrão binário de gênero e sexualidade. Sua identidade de gênero e apresentação não se limita a apenas uma categoria de gênero. As pessoas de gênero fluido podem mudar de um gênero para outro, não sendo necessariamente entre o que se entende como "homem ou mulher". 
um dos resultados da ótica machista e da busca de controle constante sobre o corpo da mulher ainda presente em nossa sociedade.

A gente está em 2015 e "qual roupa ela estava usando? Que horas que ela estava na rua? Porque ela foi pra casa tarde?" Então, assim, a origem da Marcha das vadias no Canadá foi isso. E um policial foi dar uma palestra de como evitar que elas fossem estupradas porque é a forma como a sociedade lida com isso, a mulher que tem que dar o jeito mágico de não ser estuprada. E o cara caiu no absurdo máximo de falar "Se vocês não querem ser estupradas não se vistam como vadias!". Surgiu aí. (Antônia ${ }^{17}$ )

A sexualidade da mulher, segundo este imaginário, não pode estar em evidência. Este tipo de ponto de vista fomenta no senso comum uma concepção na qual a mulher precisa se preservar para que não seja vítima de assédio que pode se tornar estupro. Este debate é o ponto central que norteia o que conhecemos como cultura do estupro, expressão que indica a normatização do estupro, geralmente pautada pela forma como uma mulher se veste, se expressa, se comporta ou manifesta qualquer tipo de interesse, é algo que a deixa vulnerável a sofrer assédio e, portanto, ser estuprada. É importante destacar que nossa sociedade favorece que esta violência continue quando constrói pensamentos, instituições e leis que subordinam e/ou invisibilizam as mulheres, pessoas trans, gays e lésbicas.

Devido à visibilidade dada ao relato do policial, em abril daquele mesmo ano, cerca de três mil mulheres se reuniram no Queen's Park em protesto contra todas as formas de opressão que sofrem. As mulheres presentes na manifestação vestiram propositalmente roupas provocantes, usaram batons vermelhos e meias arrastão. Palavras de ordem como "A saia não é justificativa para estupro" e "O corpo é meu e eu faço o que quiser" eram estampadas em cartazes durante a marcha. Após a ocorrência no Canadá, a marcha foi realizada nos Estados Unidos, Austrália, Nova Zelândia, Grã-Bretanha, Holanda, Suécia, Argentina e Índia, dentre outros países, tendo suas primeiras edições em anos diferenciados (MORAIS, 2013).

No Brasil, onde ganhou o nome de Marcha das Vadias, a primeira ocorrência foi em São Paulo, também no ano de 2011, e se expandiu para outras cidades, tais como Brasília, Belo Horizonte, Vitória, Recife, Fortaleza, Goiânia, Campinas, Curitiba, Florianópolis, Juiz de Fora e Rio de Janeiro. A cada ano, a

17 Os nomes das entrevistadas foram alterados para resguardar anonimato. Os nomes foram escolhidos por elas mesmas no momento da entrevista, exceto de Nathalia e Millena que pediram para que eu escolhesse um nome para elas. 
Marcha das Vadias RJ ganha mais adeptas em sua eclosão final e aumentam o número de mulheres que se mobilizam para construir as edições locais ou regionais do movimento. Cada edição local tem total autonomia sobre as construções de suas marchas, bem como as bandeiras de luta que englobam, sendo algumas comuns a outros estados e países, mas também são acrescidas de reivindicações de cada localidade.

\section{4.}

\section{A Marcha das Vadias do Rio de Janeiro: panorama de pesquisas e de observações}

Pelo mundo e pelo Brasil, o movimento Marcha das Vadias se inseriu dentro do contexto de luta dos movimentos feministas que buscam igualdade no acesso e nas condições de trabalho, liberdade sexual e uma nova mentalidade sobre a cultura do que é ser mulher. O movimento não reivindica uma atuação junto a outros movimentos sociais e políticos de forma institucionalizada, pois se considera parte de um contexto de renovação que supera as discussões categorizadas das três gerações do movimento feminista, visto que em sua luta há espaços de atuação para mulheres cis e trans, bem como para homens de diferentes orientações sexuais que reivindicam a defesa do feminismo. As participantes possuem total liberdade para se filiar a algum partido ou até mesmo atuar em outros movimentos sociais, mas o movimento em si é autônomo e não defende as bandeiras destes outros espaços de resistência.

Nesse sentido, é importante destacar que a Marcha das Vadias RJ 2015 se posiciona de forma contrária ao discurso defendido pelos grupos que compõem vertentes do feminismo radical, isto é, aquele tipo de movimento que recusa a integração de homens cis ou trans na luta feministas e também acredita que as mulheres trans devem ser afastadas de suas atividades. Tais movimentos argumentam que os homens são responsáveis pela condição de subordinação das mulheres e que as mulheres trans foram socializadas como homens, possuindo, portanto, certos privilégios sociais, políticos e jurídicos em relação às mulheres que nasceram biologicamente como mulheres, fêmeas.

Bom, a minha opinião nesse aspecto pode não ser a coisa mais neutra porque existe uma linha do feminismo da qual eu discordo muito que é o feminismo radical. Assim, eu não consigo compreender uma série de coisas que elas falam. Não 
compreender... assim, eu entendo exatamente o que elas estão falando, mas eu não consigo entender como é que elas não acham isso absurdo (risos). Eu tenho algumas amigas que são feministas radicais e, assim, e só lamento. Eu consigo manter a amizade e tal porque elas não são feministas radicais, mas não são tão radicais assim no aspecto da agressividade. Dá pra conversar, dá pra dialogar. Qual o problema do feminismo radical pra mim? O feminismo radical muitas vezes não reconhece mulheres trans como mulheres e pra mim isso é... não tem outra forma de enxergar isso... eu enxergo como transfóbico mesmo. (Antônia)

A Marcha das Vadias RJ, em suas diferentes edições, materializando a dinamicidade dos movimentos sociais, é composta por mulheres cis e trans e também por homens, embora estes não tenham participação ativa e constante, ou seja, não participam como protagonistas da Marcha das Vadias RJ, mas como sujeitos parceiros. A ressignificação do termo "vadias" é oriunda da perspectiva de assumir uma posição contra hegemônica à posição social que é delegada às mulheres. Além da defesa da mulher, o movimento também reivindica uma luta contrária ao ideal heteronormativo ${ }^{18}$ e monogâmico enquanto normalidade.

O nome do movimento é um dos obstáculos de sua construção cotidiana devido ao fato de que, embora as militantes se definam como atuantes em um espaço interseccional, muitas mulheres negras não se sentem representadas por ele. Estas tensões e conflitos remontam à construção do feminismo interseccional que surgiu a partir do questionamento de mulheres negras, que começaram a inserir novas concepções do que é ser mulher nos debates feministas, o que será discutido posteriormente.

Embora tenham diferenças locais (não somente dentro de sua ocorrência em diversas cidades do Brasil, mas também no mundo), a Marcha das Vadias comunga dos desafios que são colocados hoje ao feminismo. "Em outras palavras, em todos os lugares, a marcha se depara com a necessidade de gerenciar os critérios que definem quem o feminismo inclui e exclui" (GOMES e SORJ, 2014, p. 437). O movimento apresenta-se como um espaço de atuação aberto, embora haja pesquisas que abordem a dificuldade de aceitação de homens dentro dos espaços de decisão da Marcha das Vadias RJ $2015^{19}$ e que o mesmo busca atuação autônoma, sem associação a outras organizações políticas.

18 Heternormatividade é uma norma social na qual as relações heterossexuais, isto é, entre homens e mulheres são vistas como sendo corretas, devido ao fato de que possibilitam a continuidade da espécie humana por meio da relação sexual entre homens e mulheres.

19 Ver Gomes e Sorj (2014). 
Na edição de 2015, em algumas reuniões, ocorreu a tentativa de entrada de um homem cis dentro da construção. Embora ele tenha sido aceito e tenha participado de algumas decisões internas sobre a organização da Marcha das Vadias RJ 2015 sua presença não se manteve constante. As militantes se mostraram receptivas a sua presença, no entanto, após três reuniões ele não manteve contato com o movimento. Gomes e Sorj (2014) abordam que o sujeito político do feminismo, dentro da Marcha das Vadias RJ, apresenta-se mais diversificado, não se definindo nem se enquadrando pelas e nas identidades sexuais e biológicas da mulher. Esta característica é uma das marcas que diferencia este movimento transfeminista ${ }^{20}$ de outros movimentos referenciais e históricos de atuação das mulheres no Brasil.

Além da questão do aborto, a Marcha das Vadias RJ defende como premissa inicial seu posicionamento contrário à violência de gênero, por compreender que este aspecto ainda é fundamental nas relações que se estabelecem em nossa sociedade.

A expressão violência doméstica costuma ser empregada como sinônimo de violência familiar e, não tão raramente, também de violência de gênero. Esta, teoricamente, engloba tanto a violência de homens contra mulheres quanto a de mulheres contra homens, uma vez que o conceito de gênero é aberto, sendo este o grande argumento das críticas do conceito de patriarcado, que como o próprio nome indica, é o regime da dominação-exploração das mulheres pelos homens. (SAFFIOTI, 2004, p. 44)

A utilização do meio virtual (Facebook, Blog, Twitter, E-mail, YouTube, dentre outros) se faz bastante presente na marcação de reuniões, divulgação de discussões, convocação das marchas e divulgação das próprias manifestações, bem como para a publicização de pessoas ou situações que tiveram autoria na violência de gênero. A circulação de ideias e informações no meio virtual mostrase bastante importante para este movimento, bem como para as recentes eclosões de indignados que foram às ruas na cidade do Rio de Janeiro e em outras capitais brasileiras entre os anos de 2012 e os dias atuais: “(...) hoje a gente tem a Internet, que é outro veículo formador, você tem as bandeiras, algumas são as mesmas, a forma de atuar" (Virginia).

20 Como o movimento do Rio de Janeiro também se define, além de se considerar um movimento feminista. 
Pesquisas realizadas por meio de questionários na Marcha das Vadias RJ evidenciam que mais de $70 \%$ das participantes utilizam bastante a Internet, sendo o Facebook a ferramenta de acesso mais comum ${ }^{21}$. No entanto, embora a mídia digital seja constante e frequente, é na materialidade física das marchas que se verifica que tais bandeiras não se restringem a uma militância virtual. A cada ano cresce o número de adeptas da Marcha das Vadias RJ, mesmo com suas particularidades e contradições internas sobre o feminismo e sobre as diferentes formas de lutas que são atreladas às perspectivas classistas, de gênero e de raça.

A Marcha das Vadias é um dos movimentos contemporâneos que mesmo que se iniciem nas redes sociais da Internet, a ocupação permanente do espaço urbano é fundamental. "O espaço do movimento é sempre feito de uma interação do espaço dos lugares ocupados e dos prédios simbólicos visados em seus atos de protesto" (CASTELLS, 2013, p. 164). Assim, a união do espaço virtual com o espaço físico forma, segundo Castells (2013), o espaço da autonomia, na qual forças transformadoras desafiam a ordem institucional.

Outro dado importante que as pesquisas (NAME e ZANETTI 2013; GOMES e SORJ, 2014) revelam sobre a composição da Marcha das Vadias do Rio de Janeiro é que a maioria das integrantes são mulheres jovens, brancas e com alto grau de escolarização.

Os/as 102 respondentes ao nosso questionário confirmaram o que nos foi visualmente perceptível durante as duas marchas cariocas - a presença predominante de jovens mulheres: $66 \%$ deles/as tinham entre 15 e 29 anos e $68 \%$ eram do sexo feminino. Outras características relevantes dos/as respondentes são a maioria de heterossexuais (67\%), solteiros/as (83\%), com ensino superior completo ou incompleto (89\%), que estudam (70\%) e que trabalham (63\%). No que se refere à cor/raça, pode-se dizer que em nossa amostragem havia distribuição semelhante ao que foi encontrado no último censo do IBGE: $49 \%$ se declararam negros/as (pretos/as ou pardos/as) e $48 \%$ brancos/as. Perguntados/as se moravam ou já haviam morado em favela, somente 16\% afirmaram que sim. Por fim, 64\% afirmaram ter renda domiciliar total acima de $\mathrm{R} \$ 3001,00$. (NAME e ZANETTI, 2013, pp. 5-6).

Name e Zanetti (2013) apontam ainda que este também é o perfil das jovens que aderem ao movimento nas ruas. Esta composição gera algumas contradições internas, já apontadas sobre o movimento feminista negro, por exemplo, que possui as suas particularidades e não se sentem representadas pela Marcha das Vadias RJ.

21 Ver Name e Zanetti (2013). 
No plano teórico, este posicionamento encontra referências na teoria queer, que busca desconstruir a naturalidade das diferenças e das identidades. (...) enquanto buscam espaços de militância que privilegiam a coalizão da diversidade, muitos desses atores atuam concomitantemente em movimentos segmentados, como o movimento de transexuais, de lésbicas e de mulheres negras, onde buscam tratar de questões "específicas". (GOMES e SORJ, 2014, p. 444)

Essas tensões se verificam em debates na Internet e também nas reuniões do grupo. É importante destacar que a Marcha das Vadias do RJ contou, em sua primeira construção, e ainda conta com a presença de uma mulher trans e que também é prostituta. A primeira marcha foi construída também por lésbicas e mulheres cis, o que possibilita uma interpretação de que o movimento se mantém em diálogo constante com diferentes identidades devido a estas presenças constantes e marcantes.

\section{5.}

\section{A Marcha como "incubadora feminista": características do campo}

A primeira edição da Marcha das Vadias RJ foi no ano de 2011, no dia 2 de julho, na praia de Copacabana. Os temas principais foram: violência de gênero, denúncias de abuso sexual e a luta contra a cultura do estupro.

Aí quando, em 2011, a gente estava em uma reunião de ocupa, eu não me lembro o nome do movimento, que teve em São Paulo, aí teve uma reunião aqui para a gente fazer aqui também, não sei o que das liberdades, foi o IFCS22, e aí a gente viu uma notícia que aconteceu um negócio no Canadá, e "as meninas de São Paulo vão fazer a $1^{a}$ caminhada de vadias lá". Aí tava eu, Indianara, por isso que também a Marcha das Vadias tem esse discurso de Trans, não é porque a feminista abriu, foi porque a Indianara foi a $1^{a}$ trans, na $1^{a}$ organização do Rio. Tava eu, Indianara, a Laryssa Pitta, que é travesti, Jéssica Casciano, da Articulação de Mulheres Brasileiras, a Érika Portella, éramos nós 5, e aí: "Vamos fazer no Rio!". A gente aproveitou essa reunião no IFCS, fomos lá pra frente e falamos "olha, a gente quer fazer a Marcha das Vadias no Rio, a $1^{\mathrm{a}}$ reunião vai ser daqui a um mês", foi muito rápido, e foi bacana. (Virginia)

Só fui na Marcha [em 2012] e, assim, adorei. Achei a minha cara porque eu sou uma pessoa, assim, mais pro lado libertário mesmo, então, assim, pra mim fez muito sentido. E mais: é divertido, né? Você sempre ouve falar que militância e feminismo são coisas de gente chata e rabugenta e não é nada disso. (Antônia)

Em 2011 quando foi anunciada, fui procurar saber e vi umas fotos de várias minas superbonitas com umas lingeries e me desinteressei. No ano seguinte, percebi uma

22 Instituto de Filosofia e Ciências Sociais da Universidade Federal do Rio de Janeiro. 
divulgação com uma descrição mais consistente, então me juntei com umas amigas e amigos anarquistas. (Cláudia)

A segunda edição da Marcha das Vadias RJ teve sua caminhada no dia 26 de maio de 2012, iniciada no mesmo local da primeira. O direcionamento à defesa da liberdade sexual, da expressão de sexualidade e do controle sobre o próprio corpo se tornaram mais evidentes nos temas defendidos. Os temas principais foram: o fim da violência contra a mulher, a luta pela legalização do aborto, contra o Cadastro Nacional de Gestantes, contra a exploração sexual de crianças e adolescentes, a favor da regulamentação da profissão de prostitutas e pelo fim da homofobia, da lesbofobia, da transfobia e de todas as formas de sexismo e racismo. Nesta edição, houve um conflito $^{23}$ entre manifestantes e a polícia e membros da Igreja Nossa Senhora de Copacabana. Fugindo ao roteiro prédefinido, algumas das manifestantes, ao passar em frente à Igreja Nossa Senhora de Copacabana, evidenciaram seu descontentamento com a Igreja Católica. Algumas manifestantes entraram na paróquia, ficaram com os seios à mostra e gritaram palavras de ordem contra as opressões sexuais e de gênero. As igrejas cristãs são vistas pela maioria das manifestantes como um dos principais pilares de opressão e definidor de normas sociais que excluem a diversidade sexual e de gênero. Além disso, a religião e as crenças religiosas de diversas vertentes têm sido utilizadas como base argumentativa em posicionamentos contrários ao aborto e para recriminar mulheres que defendem a legalização do mesmo.

Na cidade do Rio de Janeiro, o ano de 2013 foi marcado por intensas manifestações, conflitos e atuações duras e violentas por parte da polícia militar para conter manifestantes de diferentes movimentos sociais e os indignados com os direcionamentos políticos e econômicos locais. O clima de tensão foi iniciado com o aumento da passagem de ônibus no começo do mês de junho em diversas capitais do país e que teve muitas manifestações no Rio. Tal medida foi considerada abusiva por grande parte da população, que incentivados, no começo, pelo Movimento Passe Livre (MPL) foram às ruas protestar. A truculência da polícia aumentou o clima de revolta fazendo com que outros grupos convocassem novos atos, que foram marcados pela indignação geral, pela luta por diversas

23 Veja notícia em: http://g1.globo.com/rio-de-janeiro/noticia/2012/05/marcha-das-vadiastem-tumulto-em-frente-igreja-em-copacabana.html <Acessado em: 14/12/2015> 
bandeiras e pelo grande descontentamento na atuação do Estado em garantir bens básicos de necessidade com qualidade para a população. Em meio a esse clima de tensão, a visita do Papa, agendada previamente, e a Jornada Mundial da Juventude tiveram seu local alterado e coincidiram em dia e local com parte do trajeto de passagem da marcha ${ }^{24}$. No dia 27 de julho de 2013, iniciada no Posto 5 da praia de Copacabana, tinha início a culminância da terceira edição da Marcha das Vadias no RJ. O clima acalorado de defesa de temas como a luta contra o alto índice de estupros; contra a violência sexual e de gênero; contra o machismo, racismo, desigualdade nas classes sociais, homofobia, lesbofobia e transfobia; contra a cultura do estupro; a favor da legalização do aborto; contra a interferência da religião nas políticas públicas e no corpo das mulheres; pela laicidade do Estado; pela proteção e regulamentação da prostituição; pela defesa dos direitos sexuais e reprodutivos; por justiça social e luta pela autonomia dos corpos. Os gritos de ordem e as músicas entoadas causaram imenso desconforto nos participantes da Jornada Mundial da Juventude, fazendo com que alguns desses agredissem verbalmente as manifestantes. Um confronto generalizado se formou e, assim como o ano anterior, algumas manifestantes foram chamadas a depor judicialmente sobre o ocorrido.

A edição de 2014 foi realizada no dia 9 de agosto, com seu início no posto 5 da praia de Copacabana ${ }^{25}$. Os principais temas foram a luta contra a violência sexual e a culpabilização das vítimas; contra o racismo; contra o tratamento diferenciado para as mulheres periféricas; defesa dos direitos e regulamentação da prostituição; contra violência sexual e de gênero; garantia dos direitos sexuais e reprodutivos e a defesa do Estado Laico. Esta edição contou com uma tentativa de contenção da Polícia Militar à marcha para que esta se restringisse a uma parte das ruas. No entanto, tal tentativa não obteve sucesso por muito tempo.

Considerando as reflexões de Morais (2013), que aborda os sujeitos políticos presentes na Marcha das Vadias, percebi que a minha entrada no campo deveria ser via Facebook, enviando uma mensagem à página "Marcha das Vadias Rio de Janeiro". Busquei uma ex-professora, orientadora de meu trabalho de

24 Notícia sobre a troca de local: http://blogueirasfeministas.com/2013/07/marcha-dasvadias-do-rio-de-janeiro-os-santos-que-nos-tem-quebrado/

25 Notícia sobre esta edição: http://noticias.uol.com.br/cotidiano/ultimasnoticias/2014/08/09/marcha-das-vias-reune-mulheres-e-homens-na-zona-sul-do-rio-de-janeiro.htm 
conclusão no IMS-UERJ, por saber que ela também atuava na Marcha das Vadias RJ e obtive o mesmo conselho sugerido por Morais (2013). Assim, no dia 22 de fevereiro de 2015, enviei uma mensagem e recebi a resposta de que ainda não havia ocorrido nenhuma reunião para construir a Marcha das Vadias RJ 2015, mas que seriam convocadas por meio do grupo fechado Marcha das Vadias RJ, do qual eu já fazia parte.

No dia 8 de abril, uma das meninas do grupo fez uma postagem buscando apoio na construção da Marcha das Vadias Rio de Janeiro de 2015. O local escolhido foi o Jardim do Museu de Arte Moderna (MAM). Cada participante poderia levar algum lanche para realizar um piquenique. Foi realizada uma enquete para avaliar qual seria o melhor dia e, por fim, a reunião ocorreu no dia 17 de maio, às 16h. Uma das integrantes ficou responsável por chegar mais cedo e marcar com faixas e bolas da cor roxa o local da reunião.

Ao chegar, Antônia se apresentou e logo abordou sobre a baixa expectativa que tinha sobre o número de participantes da reunião, devido ao fato de que no ano anterior ocorreram conflitos internos. Apressei-me em dizer que, além de militante, também estava ali na condição de pesquisadora e que se esta informação não pudesse ser divulgada era melhor não falar sobre o assunto comigo. Ela disse que não havia problemas e esperamos as outras pessoas chegarem. Nesta reunião, compareceram 16 pessoas. Não havia homens na reunião, no entanto, dois meninos se aproximaram e ficaram uns minutos, pois conheciam pessoas presentes e não observei nenhum tipo de rejeição à presença deles.

A reunião contou com mulheres na faixa etária entre 15 e 30 anos. Nenhuma delas se apresentou como integrante de partidos políticos, mas algumas participam de outros coletivos independentes como a Marcha da Maconha e Marcha das Vadias de outros estados. No início, optamos por uma dinâmica de apresentação, na qual me apresentei como pesquisadora e solicitei a entrada no campo. A pesquisa foi permitida com a contrapartida de que eu não somente observasse a Marcha das Vadias RJ 2015, mas que também auxiliasse na construção dela, que fizesse parte dela como militante. Aceitei as condições e seguimos com as apresentações onde cada uma apresentou-se de um jeito: umas falaram de sua formação acadêmica, outras falaram de suas orientações sexuais e as mais novas falaram da sua idade. A maioria não havia construído nenhuma outra marcha. Somente três pessoas se apresentaram como construtoras de marchas anteriores. 
As pautas de discussão foram definidas em conjunto no começo: dia e local da marcha de 2015, atividades que seriam realizadas anteriores à eclosão dela e o tema do ano. As falas foram respeitadas, uma fala por vez, e todas as pessoas que queriam expuseram suas opiniões. Surgiram discordâncias sobre a escolha do tema da marcha e sobre o local. Algumas queriam dar maior visibilidade ao tema da remoção de pessoas por conta das obras realizadas em toda a cidade do Rio de Janeiro para atender às Olimpíadas e à Copa do Mundo. Outras sugeriram tratar de questões relacionadas à legalização do aborto e à defesa de liberdade do corpo, mas esta questão ficou com resolução suspensa, pois uma das meninas averiguaria com outra militante da Marcha das Vadias RJ, que não estava presente, a possibilidade do Movimento de Prostitutas se unirem ao movimento na construção da Marcha das Vadias RJ 2015. No entanto, ficou bem claro que a escolha de um tema central não invisibilizava os demais e muito menos constrangia que qualquer pessoa levasse seu próprio cartaz.

Outro momento de opiniões diversas foi o da escolha do local da marcha. Cláudia sugeriu deslocar a marcha para a região do centro do Rio, pois esta região também atendia a um protesto por remoções de prostitutas do local. Outras defendiam a permanência da marcha em Copacabana por apresentar visibilidade e segurança. As discussões tomaram um rumo diferente quando uma das integrantes da reunião, que é cadeirante, apontou suas críticas a um acontecimento na marcha de 2014, solicitando que tanto a escolha do local quanto palavras de ordem e músicas levassem em consideração a acessibilidade que tivessem um discurso anticapacitista $^{26}$. Esse foi o momento de meu primeiro aprendizado com o movimento. Isa, com apenas 19 anos, adverte que músicas cantadas nas manifestações como "Quem não pula é machista!" evidenciam um capacitismo e que ela não se sentiria representada, caso falas assim tornassem a aparecer. Neste momento, percebi minha diferença em relação às mulheres com deficiência física,

26 Até o momento da fala de Isa esse era um termo que eu não conhecia. Após o entendimento do termo no contexto busquei leituras posteriores e recorri ao dicionário para conceituar o termo capacitismo "é um termo utilizado para descrever a discriminação, opressão e abuso advindos da noção de que pessoas com deficiência são inferiores às pessoas não portadoras de deficiência. Inclui, desta forma, tanto a opressão ativa e deliberada (insultos, considerações negativas, arquitetura inacessível) quanto a opressão passiva (como reservar às pessoas com deficiência tratamento de pena, caridade, inferioridade)" (Fonte: Dicionário Informal). O anticapacitismo seria, portanto, não reforçar tais estereótipos, ideias e concepções que fomentam a desigualdade nas relações interpessoais de pessoas com deficiência e não portadores de deficiência. 
como era o caso, e que algumas opressões nunca serão direcionadas a mim. Neste caso, minha diferença - não ser cadeirante - se transformava num privilégio que, até então, eu mesma não havia percebido no contexto dos movimentos sociais. Neste momento, embora a questão do feminismo negro já tivesse sido abordada por Antônia, percebi que seria muito importante compreender mais sobre o conceito de feminismo interseccional.

Outro ponto que foi discutido pelas mulheres que defendiam o deslocamento da marcha para o centro do Rio foi tentar responder a crítica de que muitas não se sentem representadas pela Marcha das Vadias RJ por se tratar de um movimento de "mulheres brancas e patricinhas da Zona Sul carioca". Como solução para conferir a viabilidade, a segurança e a acessibilidade do novo local, ficou determinado que no dia 30 de maio fizéssemos uma caminhada pelo centro do Rio para saber se haveria possibilidade de troca de local. Desde a primeira reunião, percebi uma característica do movimento que se reafirmou em outros encontros: a tentativa do estabelecimento de uma relação de horizontalidade na organização. As falas sempre foram respeitadas, a resolução de discordâncias sempre buscou atender a uma boa parte das integrantes, visto que a totalidade é algo muito difícil. Percebi também, não só nesta reunião, mas em todas as outras que as mulheres que organizam e as que circulam em torno deste movimento o concebem como um espaço seguro, no qual podem falar sobre suas vidas, problemas, obter conselhos, tirar dúvidas, entre outras coisas. Nesta primeira reunião, algumas meninas falaram de términos recentes de relacionamento, obtendo apoio e palavras de incentivo. $\mathrm{O}$ elogio entre as mulheres também foi frequente, tais como: "você está bonita!"; "adorei seu cabelo, mana!";

Essa descrição da primeira reunião é importante para a compreensão de que cada marcha é diferente das versões anteriores. Desde 2011, quando foi realizada a primeira edição, o movimento foi construído anualmente por pessoas diferentes, mesmo que houvesse como constatado, um número reduzido de mulheres que continuaram na construção desde a sua primeira edição, a entrada e a saída de pessoas na organização faz cada marcha ser única. E, por fim, já na primeira reunião, pude perceber como o movimento se propõe a organizar a marcha e também quais são alguns dos espaços que possibilitam o aprendizado de outras pedagogias (ARROYO, 2014). 
A segunda reunião, realizada no dia 30 de maio, teve como objetivo traçar um roteiro para a marcha, caso esta fosse deslocada para o centro da cidade. Este encontro apresentou algumas características dos encontros seguintes: (i) participação de poucas pessoas; (ii) intimidade e afetividade entre as militantes; (iii) conversas sobre edições anteriores; (iv) aparecimento gradativo dos conflitos internos ao grupo.

Ao abordarem sobre o conflito com as feministas negras, Antônia afirma que "a Marcha das Vadias RJ é uma incubadora feminista. Ela é incubadora de outros movimentos porque as minas saem daqui e vão para outros movimentos". E ao longo das observações percebi que tal afirmativa era uma constatação do que realmente ocorre.

A Antônia, que tá na Marcha desde seu início, tem uma frase que eu acho definidora, "a Marcha é uma incubadora de feministas". A gente devia inclusive explorar mais essa ideia de incubadora. Muitas manas começaram a se interessar pelo feminismo a partir da Marcha, nunca haviam participado de alguma atividade do tipo, mas foram conquistadas pelos discursos empoderadores, além de que a Marcha é bem divertida. Ela é bem pesada como uma construção, mas festivamente é uma micareta política, uma vitrine pras nossas demandas. Mesmo com todos os atritos que eu tive no ano passado, eu não saí da Marcha porque ela é muito potente. (Cláudia)

Algumas mulheres que estavam presentes no dia da marcha já haviam auxiliado na construção, mas depois resolveram atuar em outros espaços de militância. Devido aos conflitos internos e à rotina de cada participante, a Marcha das Vadias RJ ganha algumas adeptas e outras se afastam da construção a cada ano. Por conta disso, as edições nunca são as mesmas. Na edição de 2015, decidimos em uma das reuniões que nos tornaríamos uma Coletiva temporária para que a Marcha das Vadias de 2015 pudesse assinar moções de repúdio, propor documentos e ter certa autonomia. Até este momento, nesta edição e nas anteriores, nenhuma das integrantes poderia falar pela Marcha das Vadias RJ em eventos ou qualquer outro local público. Em contrapartida, o que se poderia dizer é que "estávamos construindo a marcha deste ano". Por fazer parte de um movimento independente de organizações partidárias e afins, suas integrantes adotaram essa postura. Conversas leves, brincadeiras, reuniões em bares e também na casa das integrantes da construção são marcas da Marcha das Vadias RJ 2015, embora as entrevistas relatem que este mesmo clima também era presente nos anos anteriores. 


\section{3 \\ A militância do corpo por gêneros e sexualidades}

Socialização de merda que não deixou, na verdade, ser mulheres e ter o feminismo dentro de si desde sempre. (Beatriz)

A fala de Beatriz abre o presente capítulo que trata sobre algumas possibilidades de pedagogias de emancipação na Marcha das Vadias RJ 2015. A discussão é feita por meio dos temas-chave expostos anteriormente (Capítulo 1). O tema é oriundo da análise dos dados obtidos no trabalho de observação participante e nas entrevistas, a saber: as questões sobre gênero, sexualidade e empoderamento das mulheres. Como tal, apresenta os conceitos de gênero e sexualidade e de que forma são tratados pela Marcha das Vadias RJ 2015 na militância, nos discursos e nas práticas

Assim, o capítulo trata acerca da construção do corpo como ferramenta de militância na ocupação do espaço público e na materialização das bandeiras de luta do movimento. A consciência de si, do corpo e a transgressão das normas de gênero e sexualidade alimentam o ato de empoderar-se das militantes. Tal ato é visto por todas elas como o maior aprendizado proporcionado pela vivência na Marcha das Vadias RJ 2015 e nas também nas edições anteriores.

\section{1.}

"Pedagogia vadia": sobre as formações possíveis

A diversidade de camadas sociais, identidades, formações culturais e bandeiras de luta fazem parte da militância cotidiana dos novos movimentos sociais (RUSSO, 2011; GOHN, 2011a, 2014) que passaram a gerar uma nova pedagogia para militantes e simpatizantes (ARROYO, 2014). A maior visibilidade construída ao longo da história e por meio de diferentes mídias passou a ampliar tanto a atuação quanto as redes de diálogo com as quais estes movimentos se dispõem a estabelecer. 
Os movimentos sociais se configuram como um local de aprendizagem diverso e plural, uma vez que as/os militantes destes espaços e as pessoas que são por estes aproximadas atuam dentro do coletivo visando a sua expansão, em manifestações, passeatas e apitaços ${ }^{27}$, tal como evidencia, por exemplo, Manuela:

Em 2012 foi muito fortificante, bonito, também, né? Ver mulher que assim...? Teve casos lá, super chocantes sabe? De irmã... eu lembro que teve uma irmã falando que tava participando da Marcha, porque a irmã dela tinha morrido vítima de violência, porque o namorado matou, porque não aceitou o fim do relacionamento. Então, você vendo que também ali na Marcha é um momento agregador que você também cria forças, né? Com o sofrimento do outro e você também com o seu sofrimento, você cria forças pra lutar contra esse sistema opressor que a gente vive, né?

Arroyo (2014) argumenta que dentro dos movimentos sociais todo pensamento social e pedagógico também são produtos de relações políticas externas e que também estão presentes nas experiências pessoais que o movimento propicia a partir das relações interpessoais. Assim, no caso dos movimentos feministas, que representam e defendem os interesses das mulheres, a consciência de que fazem parte de um grupo que é constantemente silenciado é uma das fontes de produção de uma nova pedagogia. Assim, palavras de ordem pronunciadas no dia da última marcha (14 de novembro de 2015) tais como "A nossa luta é todo dia. Contra o machismo, o racismo e a homofobia!" e "A nossa luta é por respeito! Mulher não é só bunda e peito!" são exemplos de como a consciência da subalternização se converte em bandeira de luta coletiva e individual a partir da experiência no movimento, mesmo que esta se dê somente no dia da marcha.

Somos chamadas de "vadias" nos espaços em que circulamos porque vivemos numa sociedade machista, racista e centrada na cisgeneridade e na heterossexualidade, que quer controlar a forma como nos vestimos, nos comportamos e até por quem sentimos desejo e a quem amamos. Ouvimos diariamente que temos que ser "vadias na cama e damas em sociedade", que "tudo bem ser lésbica, bissexual ou gay, mas não precisa sair na rua de mãos dadas com alguém do mesmo sexo", que "tudo bem ser trans, desde que seja discreta". Nos posicionamos contra esse controle e reivindicamos nosso direito à vadiagem pública, que entendemos como nosso direito a viver como queremos. Não vamos nos limitar a quatro paredes. (Manifesto de convocação para a marcha das vadias de 2015)

27 Manifestação onde se faz soar um grande número de apitos e gritos em forma de protesto. 
O manifesto foi construído por todas as integrantes da Marcha das Vadias RJ 2015 e foi publicizado no evento público do Facebook que tinha a função de convocar as pessoas para a marcha. O manifesto aponta o constante confronto entre as pedagogias normativas e as pedagogias formadas no seio do processo da militância. Tal formação é parte de uma resistência forjada na tensão entre as novas vivências coletivas e individuais, vividas nos movimentos sociais e no processo de humanização que estes proporcionam.

A hierarquização das diferenças e a violência de gênero, classe, cor e credo, características ainda marcantes do Brasil contemporâneo, são fatos sociais e geram vítimas todos os dias em nosso país e no resto do mundo ${ }^{28}$. Tratando-se da temática de gênero e sexualidade, a luta pela igualdade entre homens e mulheres promovida pelos movimentos sociais feministas é cada vez mais forte e adentra também o campo do conhecimento acadêmico. Há diversos estudos (BARROSO, 2004; SANTOS; OLIVEIRA, 2010; PRONI; GOMES, 2015; SABINO; LIMA, 2015; JORDÃO, 2015; FINCO 2015) que fundamentam políticas públicas de promoção de perspectivas igualitárias nas relações entre homens e mulheres e também entre os diferentes tipos de orientações sexuais ${ }^{29}$.

A luta dos diferentes tipos de movimento feminista e também do movimento de lésbicas, gays, bissexuais, transexuais, travestis e transgêneros (LGBTs) encontram repercussões nas mídias, nas leis e também nos ambientes formais de ensino. No caso específico da Marcha das Vadias RJ 2015, é importante destacar que devido à diversidade de gênero, orientação sexual e identidades presentes no movimento, as relações formativas que ali se estabelecem também geram pedagogias antagônicas (ARROYO, 2014) dentro do próprio movimento.

28 Para saber mais de alguns exemplos e pesquisas desses dados ver: http://www.compromissoeatitude.org.br/dados-nacionais-sobre-violencia-contra-a-mulher/ <acesso em 17/03/2016>;

http://www.cartacapital.com.br/sociedade/violencia-brasil-mata-82-jovens-por-dia5716.html <acesso em 17/03/2016>;

http://www.mapadaviolencia.org.br/ <acesso em 17/03/2016>;

http://agenciabrasil.ebc.com.br/direitos-humanos/noticia/2015-08/quase-mil-casos-deintolerancia-religiosa-foram-registrados-no-rio <acesso em 17/03/2016>.

29 O conceito de orientação sexual refere-se à formação cultural da sexualidade do indivíduo durante a sua vida que se inicia quando ele ainda nem nasceu e que permanece durante toda a sua vivência. Essa formação cultural faz com que a orientação (não opção visto que não é um processo consciente de escolha) seja formada, podendo esta também ser alterada mais de uma vez ao longo da vida de cada indivíduo. 
Segundo Arroyo (2014), as pedagogias antagônicas são os processos formativos originados nas diferenças de opiniões, ações e valores. Quando estas diferenças se confrontam dentro do espaço de militância geram modificações e/ou conciliações subjetivas que dão origem a argumentações conciliatórias que possibilitam a coexistência dessas diferenças. Dentro dos movimentos sociais, estes confrontos de formações também ocorrem nas relações entre os militantes, a partir da adoção de bandeiras de lutas específicas com suas formações culturais pregressas, isto é, oriundas do convívio com as demais instituições sociais, tais como a família, escola, a igreja e assim por diante. Assim, ao afirmar e reconhecer a subalternização as quais estão inseridas, as mulheres da Marcha das Vadias RJ 2015 percebem que possuem opressões diferentes segundo a maneira como são vistas pela heteronormativadade, pela perspectiva monogâmica, pelo racismo, pelo capacitismo e pelos diferentes tipos de discriminação que levam à exclusão dessas militantes.

(...) foi uma possibilidade de não só ler, mas ver na prática, questões importantes acontecerem, como o feminismo negro, como até a discussão mesmo de capacitismo, de também estar mais voltada para a questão trans, de discutir isso, de levar à radicalidade o oposto do essencialismo, mas a construção cultural das identidades de gênero, da sexualidade. Isso é um laboratório porque você não ta pegando um livro, lendo em um blog, você ta vendo essas coisas acontecerem lá. (Beatriz)

Estar em um movimento social como a Marcha das Vadias RJ significa, para estas militantes, desestabilizar as bases formativas nas quais foram criadas, elaborar uma nova visão de mundo, criar novas formas de aprender a ser mulher, ou seja, é preciso outra pedagogia, no sentido de novos processos de ensinar e aprender.

Nos encontros, oficinas, dias de estudo os militantes põem em manifesto essas tensões, mostram também como desconstroem as formas como foram pensadas e os processos/pedagogias com que foram tratadas como inexistentes, inferiores, subhumanas. Explicitam e reagem a esses processos/pedagogias de subalternização. Nessas reações afirmam outras pedagogias de emancipação. (ARROYO, 2014, p.39)

A partir de Arroyo (2014) compreendo a pedagogia como expressão de um processo de formação, na qual todas fazemos parte e que se modifica e tem continuidade ao longo da vida. No entanto, não se trata de uma pedagogia qualquer, mas de um modo de aprender e ensinar emancipatório.

Os movimentos sociais têm sido educativos não tanto através da propagação de discursos e lições conscientizadoras, mas pelas formas como tem agregado e 
mobilizado em torno das lutas pela sobrevivência, pela terra ou pela inserção na cidade. Revelam à teoria e ao fazer pedagógicos a centralidade que tem as lutas pela humanização das condições de vida nos processos de formação. Nos relembram quão determinantes são, no constituir-nos seres humanos, as condições de sobrevivência. A luta pela vida educa por ser o direito mais radical da condição humana (ARROYO, 2003, p. 32).

Coloco-me como parte deste processo devido ao fato de que a pesquisa, conforme já foi explicado, define-se metodologicamente como participante (DEMO, 2008) e também pelo fato de que a minha vivência no movimento no último ano também me fez perceber como estas relações se estabelecem e me estabelecem, na medida em que estava dentro do processo, aprendendo e ensinando uma pedagogia de emancipação sobre ser "como se tornar vadia". Percebi, então, que a atuação militante veicula um processo pedagógico de ensino e aprendizagem que é bastante característico dos movimentos sociais, entendidos como um campo de educação não formal.

\section{2. \\ Percepções iniciais acerca de gênero e sexualidade}

Conforme já foi mencionado, a Marcha das Vadias do Rio de Janeiro é um movimento que congrega mulheres e homens cis héteros, gays, mulheres cis héteros, lésbicas, transexuais, travestis e transgêneros.

$\mathrm{O}$ aparecimento de reivindicações sociais com base nas diferenças traz à tona movimentos de resistência, reforma e revolução, muitas vezes, veementes, sobre o lugar, os direitos, as representações, a vez, a voz, os signos e os sinais das minorias em relação a uma determinada maioria. Poderíamos dizer que a reivindicação social pelas e nas diferenças traz o apelo do reconhecimento e da garantia de direitos de identidades subalternizadas, tais como: o negro, a mulher, o gay, a lésbica, o indígena, o surdo, o jovem, o deficiente etc (ANDRADE, 2015, p. 824)

Um indivíduo, desde de que nasce, passa por um período de aprendizado no qual ele se adapta e apreende valores e pensamentos que são, de maneira geral, hegemônicos da sociedade a qual pertence. Assim, ensinamentos oriundos de referenciais históricos, culturais, morais, éticos são passados de geração em geração por meio da sociabilidade promovida nas instituições sociais, tais como família, igreja, escola, etc. e também das observações e vivências do cotidiano. Isso ocorre porque, diferentemente dos animais, o que os seres humanos herdam biologicamente não é suficiente para lhes garantir um suporte à convivência em grupo, necessária para a sobrevivência da espécie. 
Assim, as relações sociais nas quais estão inseridas as experiências humanas e as normatizações de nossa sociedade estão intrinsecamente ligadas às relações de poder. Dentro das possibilidades de tentativas de padronização social encontram-se os conceitos e as identidades de gênero e sexualidade.

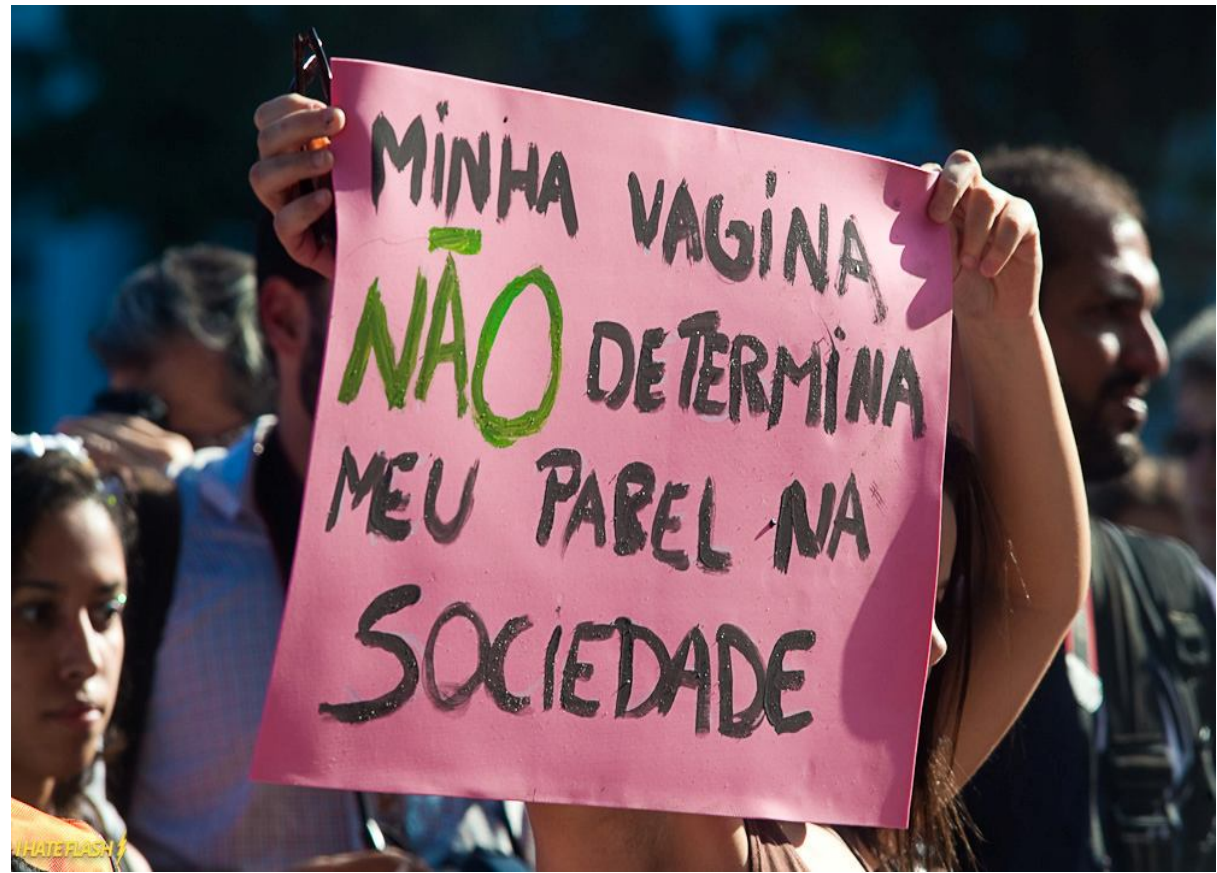

Figura 1: Cartaz sobre a relação entre biologia e a identidade de gênero Fonte: Página do Facebook Marcha das Vadias Rio de Janeiro. 


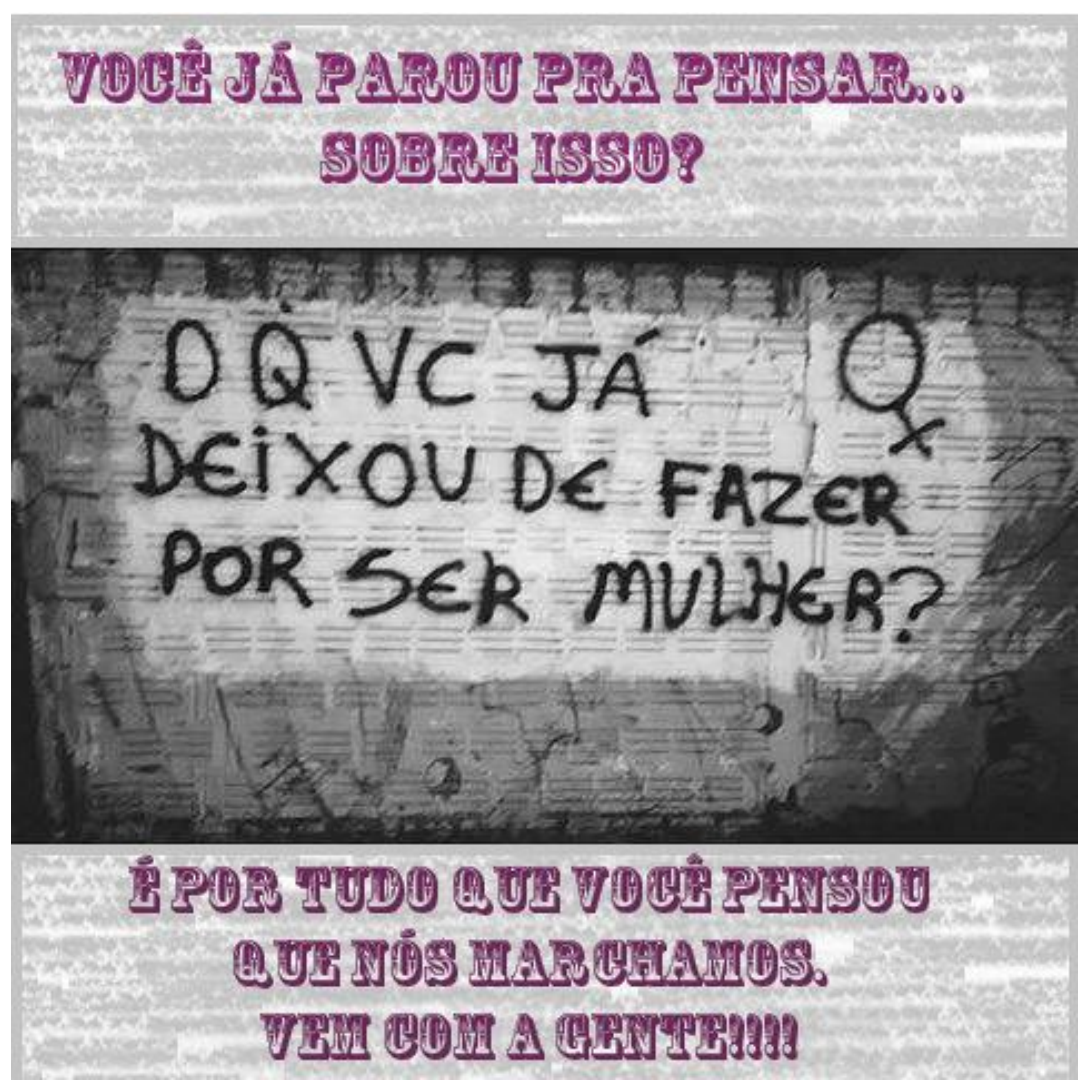

Figura 2: Contestação de papéis da mulher

Fonte: Página do Facebook Marcha das Vadias Rio de Janeiro

A Marcha das Vadias do Rio de Janeiro contesta cotidianamente as normas sociais sobre as relações entre gênero e sexualidade hegemônicas. Cartazes produzidos para a marcha (Figura 1) e a convocação para a marcha de 2015 (Figura 2) apontam as contradições em nossa sociedade baseadas em perspectivas normativas de gênero são característicos da marcha.

O gênero ao qual cada militante da Marcha das Vadias RJ se identifica faz com que cada experiência seja vislumbrada de diferentes formas. As questões relativas ao gênero refletem também o modo como se categorizam em relação às divisões sociais do mundo do trabalho, tanto na esfera pública quanto na esfera privada. Simone de Beauvoir, já no final da década de 1940, afirmava "não se nasce mulher, torna-se mulher". Tal afirmação, mais do que uma frase emblemática para o movimento feminista tornou-se uma afirmação do quanto o gênero é algo aprendido: torna-se mulher, aprende-se ser mulher, treina-se uma mulher. Já nas primeiras reflexões sobre o conceito de gênero, Beauvoir (1970, p. 11) alertava sobre a influência que a sociedade teria sobre a construção da perspectiva sobre o corpo biológico e sobre os papéis sociais a serem 
desempenhados pelo sexo feminino no mundo ocidental, principalmente. Assim, podemos afirmar que o questionamento a respeito dos papéis sociais desempenhados a partir da definição biológica dos corpos teve seu início com o diálogo entre o movimento feminista e as suas teóricas e pesquisadoras.

Joan Scott (1990) define o gênero como sendo um elemento construído a partir das relações sociais que são baseadas nas diferenças percebidas entre os sexos. Nesse sentido, o gênero funciona como um marcador das relações sociais que determina o papel que cada sexo desempenhará na estrutura social. Partindo do enfoque do feminismo pós-estruturalista, Louro, Neckel e Goellner (2005, p. 186) defendem que o conceito de gênero é uma ferramenta para a desnaturalização, que aponta para a polissemia de masculinidades e feminilidades que se articulam a muitas "marcas" sociais como classe, etnia, entre outras. Assim, as normais sociais determinam que certo gênero é esperado a partir de um referido sexo, que é observado antes mesmo do nascimento da criança.

Ora, se o gênero não é "natural", se ele é um "fenômeno social", então, ele é construído. Se é construído, então, ele é aprendido e, ainda que não explicitamente, ensinado. Neste sentido, podemos pensar em uma pedagogia de gênero. No entanto, se naturalizamos tais aprendizados eles dificilmente serão desconstruídos e reconstruídos tal como podemos perceber no Manifesto da Marcha das Vadias do Rio de Janeiro de 2015: “(...) do reconhecimento da identidade de gênero de pessoas trans sem obstáculos, para que ser homem ou mulher seja uma escolha consciente e não biologizante".

Para uma nova aprendizagem sobre os gêneros, é preciso, entre outras tantas ações, uma "pedagogia da emancipação" (ARROYO, 2014) para desconstruir os velhos papéis de como ser mulher e ser homem e reconstrui-los de uma maneira emancipada. Nesta perspectiva, faz todo sentido pensar uma pedagogia feminista para "tornar-se vadia", que aborda questões como a exposta pelo Manifesto.

Nesta pedagogia feminista vadia, o corpo é desconstruído e reconstruído, passando por processos emancipatórios de aprendizagens. A cultura ocidental tende a considerar o corpo e, consequentemente, a sexualidade, como algo particular, privado. No entanto, todos os desejos e necessidades que expressamos na busca pelo prazer são e estão sob uma vigilância pública que almejam que estas expressões estejam dentro dos padrões considerados "normais" e esperados. $\mathrm{Ou}$ seja, é esperado que um homem se apaixone e expresse desejo sexual por uma 
mulher e vice e versa. Qualquer orientação sexual que fuja ao suposto padrão de normalidade é considerada desviante e imoral.

(...) Eu nem sabia que essa era uma questão para elas (militantes da Marcha das Vadias do Rio de Janeiro) na época, de identidade de gênero, e tiveram essa coragem incrível de fazer a transição. (...) Inclusive experiências de homens trans não binários e que conversei muito: "Poxa, fulano, todo momento, eu mesma coloco em questão a minha masculinidade lésbica, e eu acho muito foda isso que você falou da bixisse em você, da viadagem em você", que é exatamente como eu me sinto, muito andrógena, querendo brincar com ambos os gêneros. (Beatriz)

As fronteiras entre o que define o gênero, a sexualidade, as identidades biológicas e as formas com as quais cada militante quer ser identificada socialmente não são rígidas. Assim, a liberdade de poder se apresentar como quer, como se sente bem e ser respeitada por isso é imperativo no movimento. Não há julgamentos morais internos e há um constante incentivo para que cada pessoa tenha total liberdade de escolher o que quer ser e como quer ser. Esta lógica subverte diretamente as normas sociais a respeito, principalmente, da sexualidade.

É importante destacar que nas sociedades ocidentais não há comportamento humano que não seja moralmente avaliado. Tais avaliações morais se constituem como um fato social. A sexualidade, ao contrário do que pode pensado por muitas pessoas, não é apenas uma questão de instintos ou de impulsos, dominados pela natureza, genes ou hormônios. Também não é algo que se resuma ao prazer e ao afeto somente.

Gagnon (2006, p. 406) afirma que "não temos um comportamento sexual biologicamente nu, mas uma conduta sexual socialmente vestida. $O$ comportamento sexual é constituído socialmente, de modo que se transforma em conduta sexual". Nesta mesma perspectiva, afirma que "a vida sexual se assemelha a toda vida social: é uma atividade provocada pelas circunstâncias sociais e culturais, e uma atividade que difere de uma época histórica para outra" (GANGNON, 2006, p. 215).

Comparando necessidades relacionadas à sexualidade àquelas que dizem respeito à alimentação, Rubin (1998, p.106) argumenta que:

A sexualidade humana não poder ser compreendida em termos puramente biológicos. Organismos humanos com cérebros humanos são necessários para culturas humanas, mas nenhum exame do corpo ou de suas partes pode explicar a natureza e variedade dos sistemas sociais humanos. A fome do estômago não dá nenhuma pista para as complexidades da culinária. O corpo, o cérebro, a genitália, e a capacidade de linguagem são todos necessários para a sexualidade humana, mas eles não determinam seu conteúdo, suas experiências, ou suas formas 
institucionais. Além disso, nunca nos deparamos com um corpo sem as mediações que as culturas lhe acrescentam.

As questões relacionadas à sexualidade não podem ser mensuradas apenas a partir de aspectos associados ao gênero. Analisarmos socialmente as questões relativas ao gênero e à sexualidade tomando como ponto de partida somente o sexo biológico embasam atitudes de discriminação e mantém desigualdades e exclusões. Tanto gênero quanto sexualidade são produtos de condições históricas, sociais e culturais nas quais os indivíduos estão inseridos. Assim, suas formações são oriundas de um processo de formação pessoal contínuo e não linear.

\section{3.}

\section{Novos feminismos em marcha: transgressões culturais}

A Marcha das Vadias das Vadias RJ enquanto uma das representações dos novos movimentos sociais busca transgredir a nossa cultura que possui uma série de normais, comportamentos e expectativas que definem o que é ser mulher. A atuação independente de outros movimentos sociais institucionalizados em forma de partidos políticos se apresenta necessária para garantir a continuidade da autonomia das militantes em relação a atuação conjunta e em relação a uma atuação do próprio movimento. A necessidade de construir espaços nos quais as militantes se sintam seguras das opressões sociais é um grande motivador e embasa esta opção da Marcha das Vadias RJ nas edições, de 2011 à 2015.

Então, assim, eu acho que todos os meus ciclos acabam sendo espaço de acolhimento e de irreverência. Mas eu não vejo isso nos movimentos sociais de uma forma geral, eu acho que muito pelo contrário, como nos lugares... a Marcha das Vadias é um lugar de... você pode ter partido, mas normalmente as pessoas não tem, então não é uma disputa partidária, eu vejo que quando há uma disputa partidária nos lugares, os lugares ficam muito duros e muito difíceis das pessoas se acolherem, se receberem porque elas estão sempre levando uma bandeira né? (Heloisa)

Historicamente, a mulher ocupa um lugar secundário nas formações culturais ocidentais. No Brasil, a idealização da mulher é datada desde a época da colonização em que mulheres eram trazidas à Colônia a partir de duas definições binárias, para ser esposa ou para ser prostituta. A mulher esposa assumiria as tarefas domésticas e a ela seria delegado amplo uso do espaço privado. Enquanto que ao homem, a utilização do espaço público sempre foi amplamente incentivada. 
A partir da reprodução e reforço dos papéis normativos de gênero (SCOTT, 1990), os homens aprendem desde cedo que possuem a tarefa de trabalhar e sustentar suas famílias, enquanto que as mulheres aprendem que devem saber cuidar da casa e dos filhos. Esta divisão social do trabalho fez com que a utilização dos espaços extra domésticos pelas mulheres fosse sempre vigiada pelo olhar masculino. Assim, a partir da regulação masculina, a relação histórica das mulheres com o espaço público, isto é, fora dos limites da casa, era bastante limitada. Uma das consequências deste contexto histórico é a aprovação tardia de que mulheres pudessem eleger e /ou concorrer a cargos políticos públicos. No Brasil, o primeiro voto feminino foi em 1932, por exemplo. Compreendo como espaço público não só a participação política, mas também o espaço de fala, o que acarreta que as ideias aceitas e defendidas sejam majoritariamente masculinas, enquanto que os posicionamentos femininos são relegados para um segundo plano e/ou ao lugar da invisibilidade.

E.: (...) Você acha que a luta das mulheres teve avanços?

Eu acho, né... assim... Com relação a luta das mulheres eu acho que hoje... não só hoje, mas em todos os momentos as mulheres têm se colocado. Eu vejo que antes as mulheres aceitavam mais as coisas... E eu vejo pelo próprio histórico das mulheres da minha família e hoje, por mais que ainda seja pouco... Essa participação da mulher na política, é.... Mas, assim, o fato de também ter uma representante feminina [na política] isso mostra também que de alguma forma a gente consegue... sei lá de... chegar ao poder, de alguma forma, eu acho que isso dá uma força, assim. Então, eu acho que hoje pela participação das mulheres em várias instâncias, sabe, não só com relação ao feminismo, mas em outros debates, em outras áreas. (Manuela)

Tal mentalidade social tem sido reforçada pela religião - especialmente, as cristãs - e, durante o século XIX, também foi reforçada pela ciência, política, escola, família, artes, etc. A noção do dimorfismo sexual, isto é, a diferença biológica entre homens e mulheres como formadora de identidades dentro do contexto científico é recente e tem fortes consequências nesta discussão. A distinção biológica entre homens e mulheres foi amplamente utilizada como fator determinante das funções sociais a serem desempenhadas por elas e eles. Às mulheres caberia a maternidade, visto que lhes foram determinadas "naturalmente", devido ao fato de que as mesmas poderiam gestar uma criança em seu ventre, enquanto que aos homens caberiam os trabalhos intelectuais, externos e o provimento da casa. O relato de Manuela nos traz um exemplo desta 
exclusividade de papéis que a sociedade compreende como sendo exclusivamente

das mulheres ou dos homens:

Eu venho de uma família assim, onde minha tia teve que trabalhar a vida toda dentro de casa. Meu tio era marinheiro e tal... tava seis meses fora e ela não podia trabalhar fora e, às vezes, atrasar pro dinheiro vim, tinha que mandar, que cair aqui e ela ficava naquele desespero e não podia trabalhar fora, imagina a situação dela, assim. Eu não cheguei a passar por isso, mas ela me contou isso, assim. Então, eu sempre ficava me questionando, assim: "Até que ponto ele tinha esse poder, assim de fazer com que... ela tinha o desejo de trabalhar fora e ela não ia simplesmente porque ele não deixava?" Ela também veio de uma família, meus avós, super opressores, a maioria das filhas casaram pra poder sair de casa, porque não tinham a liberdade de sair, de fazer as coisas.

[...]

Teve essa questão familiar, né? De tá grávida, não casada. Essa pressão da família e também na própria faculdade. Cara, eu lembro assim... que tinha uma garota... eu sei que isso tá muito ligado à questão psicológica, né? Você fica mais frágil, às vezes, e tal... Eu tinha acabado de começar a faculdade e eu fiquei grávida, tipo: "Caraca! Nossa! A gente acabou de entrar na faculdade, a gente tá no primeiro período. Nossa é uma pena, né? Porque você não vai conseguir concluir" Começou falando várias coisas assim, que quando a mulher fica grávida, fica com várias responsabilidades com a criança e aí, realmente, eu comecei absorvendo aquilo pra mim, sabe? E... eu acho que essa questão pra mim que é meio velada isso na sociedade... A verdade é que a sociedade faz essa pressão psicológica pra mulher e acaba sendo muito pior do que uma agressão em si, por que dependendo, às vezes, quando você apanha... apanho, saro, beleza... você segue a vida. (Manuela)

Durante o século XIX, a sexualidade estava diretamente relacionada aos aspectos reprodutivos. O que hoje identificamos como heteronormatividade, conceito já definido anteriormente como a normatização das relações afetivas e sexuais que ocorrem, exclusivamente, entre homens e mulheres, foi colocado no centro das relações sexuais da nossa sociedade, bem como os comportamentos delegados aos homens e às mulheres para a reprodução da espécie humana.

Observando fotografias, vídeos e demais produções de todas as edições da marcha das Vadias do Rio de Janeiro, desde a sua primeira edição, pude perceber que é comum a presença de casais homoafetivos e que as trocas de carinhos entre estes casais também são utilizadas como atuações políticas. Nossa sociedade ainda se mostra intolerante à presença de casais compostos por pessoas do mesmo sexo.

Quando eu descobri... Lésbica a gente usa agora, mas na época, quando eu me descobri maria-homem, era o termo que se usava em 74,75 , eu fiquei muito apavorada. Queria contar para o meu pai, que eu nunca tinha mentido para ele, eu queria contar para minha mãe, e foi muito doloroso, porque eu queria usar uma expressão que eu me sentisse confortável com ela, que não me sentisse incomodada.

E: Você tinha quantos anos? 
Eu tinha acabado de fazer 15 anos. Eu olhava para cara do meu pai e ficava assim: "Maria-homem, mulher-macho, caminhoneira, sapatão". Tudo que era esculachado, e aí eu tive que falar para ele mesmo que eu era "mulher-homem", e ele chorou, e a preocupação dos pais naquela época era: "Você não vai sair agora cortando o cabelo e se vestindo de homem?" "Ok" "Não quero aqui dentro de casa" “Ok, também!". Ou seja, não quer em casa, na rua não pode (.....). (Virginia)

Atrelado a esta discussão, insere-se o conceito de gênero (SCOTT, 1990) que é definido e construído socialmente a partir da determinação biológica visível. Atualmente, a influência dessas prerrogativas sexuais e sociais ainda embasa argumentações de cunho machista, homo/trans/lesbofóbico e heteronormativo, que delegam um lugar secundário ao feminino.

No plano teórico, este posicionamento encontra referências na teoria queer, que busca desconstruir a naturalidade das diferenças e das identidades. (...) enquanto buscam espaços de militância que privilegiam a coalizão da diversidade, muitos desses atores atuam concomitantemente em movimentos segmentados, como o movimento de transexuais, de lésbicas e de mulheres negras, onde buscam tratar de questões "específicas". (GOMES e SORJ, 2014, p. 444)

O termo queer aparece na década de 1990. "De origem na língua inglesa, queer significa estranho, esquisito, raro, utilizado no sentido pejorativo para ofender homens e mulheres homossexuais" (BASTOS, 2015, p.84). A utilização do termo, assim como do termo "vadias", foi ressignificada pelo movimento LGBTs em uma vertente pós-identitária, que tem relação ao surgimento das teorias pós estruturalistas que, de maneira geral, abordam que os aspectos de classe não explicam sozinhos os problemas estruturais de nossa sociedade. Apresenta-se, então, como um conceito que defende a desnaturalização do conceito de gênero e sexualidade.

Desde então, o termo tem sido utilizado como marcador da instabilidade das identidades. Para a teoria queer as identidades sexuais pouco contribuem no reconhecimento das sociedades multiculturais, na medida em que manter-se-iam os sistemas binários de identidade - homem/mulher, heterossexual/homossexual, branco/negro, etc. - e, portanto, de poder desigual entre os sujeitos. (BASTOS, 2015, p. 87)

No entanto, o entendimento e a adoção do termo e da militância intersecional se apresentam, para as entrevistadas, como o conceito que mais se aplica à caracterização da Marcha das Vadias RJ. As discussões sobre teoria queer são essenciais para o entendimento das questões relativas à fluidez dos gêneros e do exercício das sexualidades e como tais questões são trabalhadas dentro do movimento. 
Então, cara, a gente não pode abrir mão de identidade, sabe? Essa coisa queer... Calma! É queer no ideal para você dizer que as relações são fluidas, para você defender em um horizonte lá na frente que qualquer tipo de relação deve ser respeitada, vale a pena, mas, eu acho que a ideia politicamente de identidade é muito forte, muito necessária. (Beatriz)

A partir das observações das reuniões e da roda de conversa sobre "Corpos que fogem à norma" pude perceber que todas as entrevistadas já ouviram falar de teoria queer e sem dúvida as que estão inseridas no ambiente acadêmico conhecem esta conceito de forma mais aprofundada. O movimento não reivindica para si uma teoria acadêmica no qual se enquadre e que apresente autores e discussões teóricas que sustentem as argumentações em espaços de trocas de experiências. A Marcha das Vadias RJ 2015 era composta, em sua totalidade, por mulheres acadêmicas (e aqui me incluo), no qual as discussões sobre a teoria não estão distantes de nossas rotinas de estudo. Sendo assim, uma troca de nossas experiências na área do conhecimento formal ocorreu, algumas vezes, e a conclusão foi a de que "estamos numa bolha", expressão utilizada por duas entrevistadas nas reuniões.

Na roda de conversa, evento no qual estiveram presentes outras pessoas que não estavam construindo a Marcha das Vadias RJ 2015, o próprio tema de debate e as falas que surgiram a partir do tema evidenciaram que o termo desconstrução e seu entendimento fazem parte da rotina dessas pessoas. Nesse sentido, as percepções sobre a existência de diferentes possibilidades de identidade de gênero e de sexualidade e de que estas não são fixas, mostra uma grande aproximação com as teorias pós-críticas. Além disso, a participação de duas entrevistadas em eventos acadêmicos do ano de 2015 sobre teoria queer e demais teorias póscríticas sobre gênero e sexualidade mostram que tais aproximações não podem ser totalmente separadas da construção do movimento, devido ao fato de que suas vivências acadêmicas também estão inseridas em seus espaços de militância política.

Embora tenham diferenças locais (não somente dentro de sua ocorrência em diversas cidades do Brasil, mas também no mundo), a Marcha das Vadias RJ comunga dos desafios que são colocados hoje ao feminismo. "Em outras palavras, em todos os lugares, a marcha se depara com a necessidade de gerenciar os critérios que definem quem o feminismo inclui e exclui" (GOMES e SORJ, 2014, p. 437). 
O recorrente e constante diálogo com prostitutas e diferentes identidades de gênero e sexualidade ressignifica diariamente o feminismo da Marcha das Vadias RJ. Tais ressignificações embasam a adoção da perspectiva instersecional da atuação política de suas militantes. O principal motivador para tal característica é o fato de que mulheres trans e prostitutas sempre estiveram presentes na construção da Marcha das Vadias RJ ou mesmo bastante próximas a ela e isso não poderia passar despercebido nas construções.

E.: Você colocou que não é a marcha em si que ensina muito, são as pessoas, você aprende com as pessoas. Você acha que as pessoas aprenderam algo com você?

(...) muitas amigas que dizem que aprenderam muito comigo, com minhas experiências, com minhas falas. (...) Principalmente sobre a identidade de gênero e sobre o direito das profissionais do sexo e isso tudo que está nesse âmbito. As pessoas sempre dizem: "Nossa, aprendi muito a escutar... escutando você aprendi muito sobre essas pessoas e sobre os direitos dessas pessoas. Visões que eu tinha antes caíram totalmente por terra". Então, eu acho que esses momentos são muito importantes. (Indianara)

A presença, militância e história de vida de Indianara desperta admiração em outras militantes, que desenvolveram laços de amizade e companheirismo entre elas. Após a construção deste ano, a militância enquanto uma socialização política (MESQUITA, 2003, 2006, 2008) se mostrou um dos pilares de construção da Marcha das Vadias RJ 2015 devido ao fato, principalmente, porque éramos poucas.

Este tipo de socialização presente na Marcha das Vadias RJ 2015 também se mostrou uma importante base para a compreensão das diferentes identidades de gênero que se aproximam do movimento e como elas se relacionam.

E a gente sempre depois das reuniões acabava em bar, não é? Então, a gente sempre falava: "Nossa, a gente faz uma Marcha das Vadias que ela é irreverência desde o dia das reuniões até o dia da marcha em si”. Eu acho que é o que a gente mais precisa, assim, espaços que a gente consiga tirar o peso do dia a dia. (Heloísa)

A análise das observações e das entrevistas aponta que a leveza do movimento e a diversão apontada por todas as entrevistadas é oriunda da respeitabilidade dos laços de amizade entre as militantes e é o maior motivador para que muitas voltem à organização nos anos seguintes.

\section{4 . \\ O corpo como caligrafia de protesto}

E.: Na Marcha das Vadias se ensina a? 
Se ensina a se libertar, a ser dona do próprio corpo, a se defender do que vai ser cobrado. A ser mais porradeira, poder vestir a roupa que quiser, mas se vier pra cima de mim eu vou gritar, ou dar uma porrada e sair correndo, enfim, a se empoderar mesmo, tanto no discurso quanto na prática. (Cláudia)

O corpo das mulheres na Marcha das Vadias das Vadias RJ parece possuir um significado diferenciado do que possuía para as gerações anteriores do feminismo. O que antes era uma autonomia atrelada somente a reivindicações que defendiam a descriminalização do aborto, saúde das mulheres e participação nas decisões de planejamento familiar, hoje o corpo possui um significado muito mais amplo. Le Breton (2014) pontua que atualmente uma reflexão sobre o corpo leva a uma intervenção direta do indivíduo sobre a parte visível de si, isto é, sobre seu próprio corpo.

Nesta perspectiva, o corpo é visto e utilizado como uma forma simbólica que constitui um universo de significados e valores que se encenam e se movimentam constantemente. Este corpo torna-se, então, uma realidade pessoal, uma apresentação de sua identidade. $O$ corpo expressa uma condição humana que funciona como apresentação da identidade de mulheres e homens e de suas relações com o mundo. Funciona como um espelho que atua diretamente na maneira como os outros nos interpretam a partir dos significados que queremos que a nossa estrutura física transmita. "Por meio do corpo, o indivíduo assimila a substância da sua vida e a traduz para os outros por meio de sistemas simbólicos que ele divide com os membros de sua comunidade" (LE BRETON, 2008).

A utilização do corpo é central na forma de atuação da Marcha das Vadias RJ. É comum em todas as eclosões do movimento que o corpo assuma dois papéis. O primeiro é sua utilização como meio de protesto, onde palavras de ordem são escritas nos corpos, bem como a prática do topless como subversão à opressão. Mostrar os seios significa, na Marcha das Vadias, romper com os padrões de vestimenta que são impostos, uma vez que todos os homens podem, por exemplo, andar livremente sem camisa nas ruas sem serem atacados, tal como foi amplamente registrado na marcha que foi a culminância de 2015 e retratada na Figura 3. 


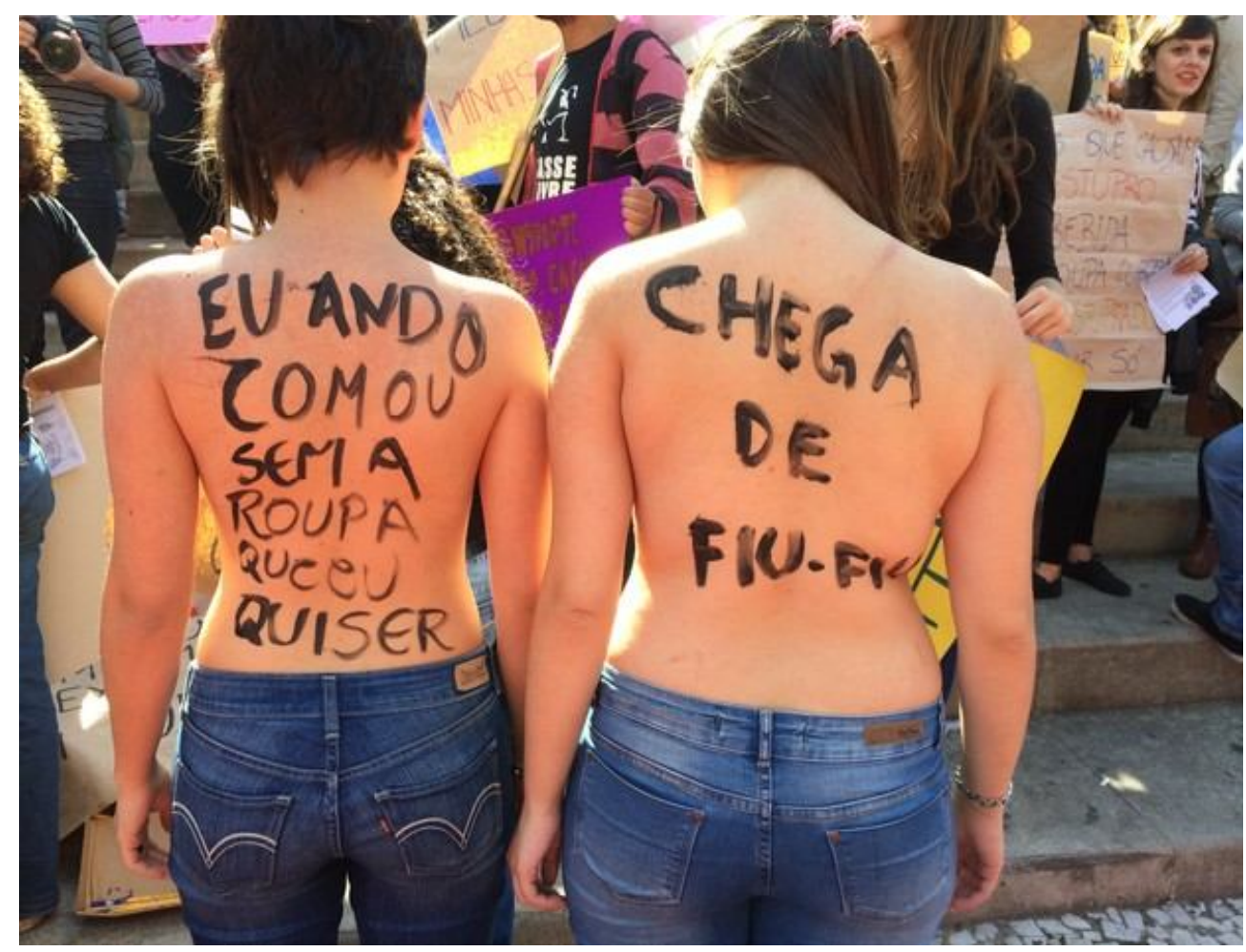

Figura 3: Corpos escritos.

Fonte: acervo da pesquisa

O segundo papel do corpo é o que este se traduz como um objeto de reivindicação (Figura 3 e Figura 4) de autonomia das mulheres sobre elas próprias. Harvey (2012) fala sobre a legitimação do uso do corpo como espaço político, seja no contexto de ocupar um espaço que não é "delegado" aos que protestam, bem como na explicitação das divergências culturais e identitárias que são visíveis no corpo. "O poder coletivo de corpos ocupando um espaço público continua sendo um bom instrumento de oposição quando o acesso a todos os outros meios está bloqueado" (HARVEY, 2012, p. 61). O corpo também é central na composição da Marcha das Vadias RJ quando se torna objeto de reivindicação como, por exemplo, na defesa da legalização do aborto, pautada no empoderamento da mulher sobre si. 


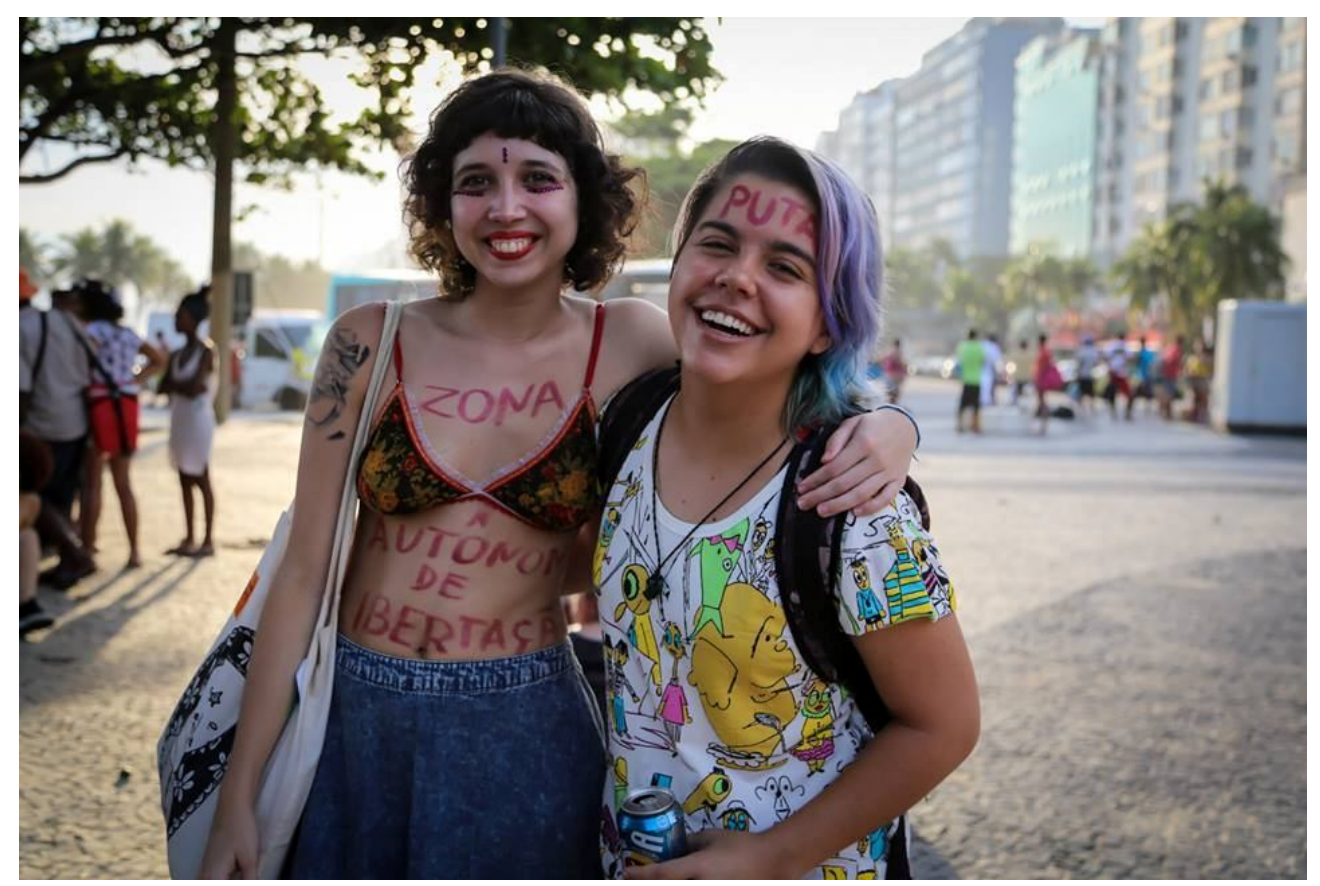

\section{Figura 4: Protesto no corpo.}

Fonte: Página do Facebook Marcha das Vadias Rio de Janeiro.

Gomes e Sorj (2014) defendem que, atualmente, obter autonomia sobre o próprio corpo extrapola a temática do controle da reprodução e busca por melhorias da saúde feminina. A experimentação do próprio corpo transcende a luta por políticas públicas na área da saúde ao reivindicar uma nova cultura sobre a apropriação do corpo por si e pela sociedade, ou seja, nas relações interpessoais.

Hoje chamamos a atenção de todas as pessoas à urgente necessidade de nos posicionarmos contra o conservadorismo que se amplia no Congresso Nacional. A Constituição Federal traz, dentre seus princípios democráticos, a laicidade e a não discriminação e temos acompanhado o pavoroso desrespeito às conquistas históricas dos movimentos sociais diariamente naquela Casa que deveria nos representar. (Manifesto da Marcha das Vadias RJ 2015)

A Marcha das Vadias RJ 2015 buscou fazer uma retrospectiva das edições de marchas anteriores, mas, diante da onda conservadora que tomou conta do Congresso Nacional que discutia cotidianamente projetos de leis que feriam diretamente a autonomia das mulheres sobre o próprio corpo e poderiam, inclusive, representar um retrocesso em direitos já conquistados legalmente, como foi o caso do "Estatuto do Nascituro", projeto de lei 478/2007, muitas palavras de ordem e cartazes foram relacionados a esta temática:

O corpo é nosso!

É nossa escolha!

É pela vida das mulheres!

Legaliza! 
Ooo! O Cunha ${ }^{30}$ é ditador

Ooo! O Cunha é ditador!

A sensualidade dos corpos é algo valorizado pelo movimento, bem como o constante questionamento dos padrões contemporâneos de beleza feminina. A exigência do reconhecimento de diferentes corpos e suas inúmeras esculturas é uma das potências do movimento.

É, pedagógico, nesse sentido mesmo em todas as questões que ela traz, da autonomia do corpo da mulher, de tentar evidenciar que a mulher poder dar para quem quiser, inclusive outra mulher, pode ser prostituta, pode tudo, que a mulher pode tudo, acho que é a grande lição. É o que a marcha tenta levar para a rua. (Beatriz)

Era uma provocação, um corpo gordo feminino com os peitos de fora, para prática do Beijato $^{31}$ em 2012. Foi um ato muito empoderador pra mim. (Cláudia)

O movimento aposta na nudez como um frequente instrumento gerador de impactos nas marchas. As críticas às normas de gênero e padronizações da sexualidade estão sempre em evidência nas expressões de libertação dos corpos. A naturalização de partes físicas que são sexualizadas somente em mulheres é explícita nas utilizações do corpo como meio de protesto (Figura 3, Figura 4 e Figura 5), um corpo-bandeira (GOMES e SORJ, 2014).

Tem até um aspecto carnavalesco de catarse coletiva, a possibilidade de tirar o sutiã num espaço público, coisa que nunca puderam fazer, inclusive várias minas que não conseguem nem dormir sem sutiã livram-se disso durante a Marcha. Eu mesma, em ato, foi a primeira vez que tirei a blusa. (Cláudia)

Esta defesa de autonomia acaba sendo uma das atrações de novas participantes para a construção. A análise das entrevistas aponta que esta inclinação é devido ao fato de que muitas mulheres, mesmo as que não se reivindicam feministas, buscam defesas contra o assédio sexual e moral, a violência patriarcal e a objetificação dos corpos femininos, bandeiras de luta explícitas na Marcha das Vadias RJ. A associação de liberdade sexual com autonomia dos corpos é bastante frequente no discurso do movimento que almeja

30 Eduardo Cunha é presidente da Câmara dos Deputados do Brasil desde o ano de 2015 e tem sido o protagonista da proposta de diversos projetos de lei que interferem diretamente na autonomia e na liberdade das mulheres, tais como as questões relativas ao aborto e à violência física.

31 Beijato é o nome dado a uma das formas de protesto contra homofobia e lesbofobia no qual pessoas do mesmo sexo se beijam em defesa da expressão de diferentes orientações sexuais. 
desconstruir a naturalização da "posse" da sociedade como um todo sobre o corpo da mulher.

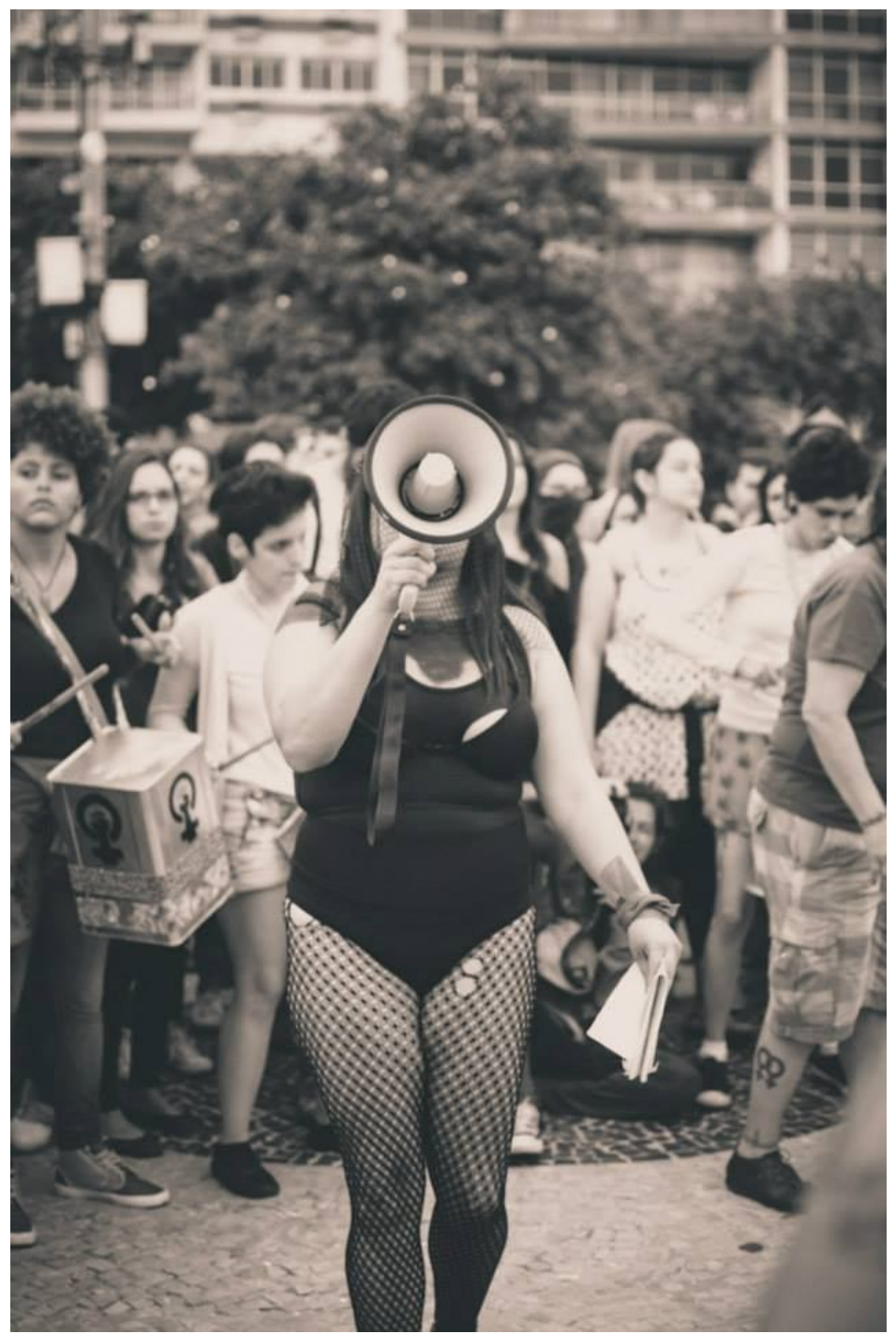

Figura 5: Roupas performáticas.

Fonte: Página do Facebook Marcha das Vadias Rio de Janeiro.

A este processo de desconstrução, as entrevistadas apontam a importância da Marcha das Vadias RJ como fonte e propulsor do empoderamento. As pedagogias antagônicas (ARROYO, 2014) vivenciadas no cotidiano da militância são oriundas do diálogo e dos conflitos entre as entrevistadas em conjunto com as mulheres que se aproximam do movimento ao longo da construção e também dos conflitos individuais gerados da apreensão dos discursos militantes e as contradições experienciadas no cotidiano da sociedade. Este processo coletivo gera uma nova consciência política individual no qual estas mulheres passam a se 
auto empoderar, no sentido de tomar para si a percepção de sua posição histórica e cultural de subalternização e revidar contra isso em diferentes formas de luta.

E.: Na Marcha das Vadias se ensina a?

Vadiagem. (risos) (...) é o uso da sexualidade pra si mesma, sem, sem se prender no controle social da instrumentalização do desejo, da mulher, do desejo de ficar entre quatro paredes. A vadiagem na rua é isso pra mim, é... Eu não sei se eu falaria a conquista do espaço público, mas a intervenção feminina. A intervenção da mulher no espaço público. (Heloisa)

O questionamento em forma de grito, nudez, protesto, proteção e autoproteção feminina e a criação de ambientes propulsores deste discurso coletivo feminista potencializa o movimento na medida em que a irreverência torna-se um motivador para novas atuações no cotidiano das entrevistadas.

Êêêta, êta, êta, êta,

O Cunha quer controlar minha buceta ${ }^{32}$

Ô Jô Soares, vou te falar:

- O batom vermelho você tem que respeitar!

Um dos pontos de destaque atribuído ao movimento como fonte de importância refere-se a este empoderamento que gera novas ocupações nas redes sociais, nas relações interpessoais, nas ruas e na cultura contemporânea.

E "Pra rua vadiagem!" é tipo: "Nós vamos ocupar o espaço público com a vadiagem!" Então, nós vamos ser lésbicas, sapatões, bichas, viadões, nós vamos ser mulheres heterossexuais que são donas dos próprios corpos, nas ruas. A gente vai andar na rua à noite e a gente não pode ser estuprada porque tá andando na rua à noite. A gente vai usar saia curta. A gente vai viver o quanto a gente quiser na noite. Então, eu acho que esse "Pra rua vadiagem!" resume bem o que é a marcha das vadias. (Heloisa)

\section{5.}

\section{No Brasil, corpos despidos só no carnaval!}

Em um país cujo um dos chamarizes para o turismo é o objetificação dos corpos das mulheres, a repercussão que os protestos da Marcha das Vadias RJ provoca em parte da mídia ou em algumas pessoas que presenciam a culminância é, no mínimo, incoerente. Por exemplo, na marcha de 2015, com a ajuda de registros de colegas do mestrado, do grupo de pesquisa e de meu orientador acadêmico, recebi relatos que alguns homens tentaram assediar as mulheres que estavam de topless e houve transeuntes que gritaram palavras ofensivas às

32 Parodiando a música Tieta de Caetano Veloso. 
manifestantes, dizendo que se as mulheres queriam direitos deviam se dar ao respeito, numa clara oposição aos corpos desnudos que caminhavam pela orla de Copacabana gritando palavras de ordem contra a opressão que as mulheres sofrem.

No entanto, considerando a nossa cultura e a estrutura patriarcal e machista na qual estamos inseridas, essa resistência à luta pela autonomia dos corpos é apenas uma das consequências punitivas que as mulheres que lutam cotidianamente e de diferentes maneiras, sem nem precisar mostrar partes do seu corpo sofrem.

As demandas pela autonomia das mulheres presentes na Marcha das Vadias estão baseadas na ideia de independência dos corpos e nos ideais de liberdade de escolha (de parceirxs, de orientação sexual, de fazer ou não um aborto), questões relacionadas a um referencial liberal que concebe a liberdade em termos de uma experiência individual (e corporal). Também se faz presente uma estética sexual que faz referência à produção discursiva dos corpos, desnaturalizando papéis sexuais e hierarquias. A luta por autonomia e independência está atravessada pela afirmação do corpo individual e livre. (MATTOS, 2014, P. 4).

Como uma das alavancas sociais contemporâneas que almeja transformação sociocultural por meio de uma transformação individual e coletiva da estrutura social, as militantes da Marcha das Vadias RJ padecem de desafios cotidianos que se materializam em diferentes formas. Um levante no qual a maioria das manifestantes são mulheres demanda uma resistência diferenciada por parte do Estado, ao menos em teoria, devido ao fato de que mulheres são consideradas o "sexo frágil". No entanto, as repercussões das edições anteriores da Marcha das Vadias RJ, incluindo a edição de 2015, foco desta pesquisa, apontam que as maiores resistências materializam-se de forma sutil. A sociedade, que objetifica os corpos femininos, ainda não aceita que estes mesmos corpos reivindiquem autonomia e liberdade. A quase nudez e a sensualidade cabem - ou não causam estranhamento - nas areias, mas não nas ruas de Copacabana, pedindo respeito aos seus corpos. É sobre esta contradição que falamos.

Então, assim, eu acho subversivo sim você colocar o peito pra fora. O peito é uma parte do corpo humano, o mamilo todo mundo tem. Eu não entendo o porquê dessa histeria, quer dizer, eu entendo. Essa histeria é porque o corpo da mulher não é dela. A gente na tem agência, não tem autonomia sobre o nosso corpo, entendeu? Então, assim, quando as pessoas falam: "Vocês estão fazendo manifestação para ser vadia", não é isso, mas e se fosse? Qual o problema? Eu acredito que a liberdade sexual e a mulher andam junto, caminha junto com o respeito que a mulher tem do outro. Se a mulher tiver autonomia sobre o corpo dela, se ela tiver liberdade sexual, se ela realmente tiver essa liberdade, no dia em que isso acontecer, o cara não vai se sentir no direito de enfiar a mão em você e de te 
assediar na rua porque ele vai respeitar a sua autonomia, então, pra mim caminha junto. Pra mim, não é uma reivindicação menor a liberdade sexual, entendeu? Liberdade sexual vem junto com a autonomia. A gente só vai ter liberdade sexual quando... é um pacote, entendeu? É tudo junto. (Antônia)

Todas as entrevistadas destacam em suas falas a importância que o movimento possui para a formação de novas redes de contato, de militância e para a construção de novas formas de transformação social. Quando perguntadas sobre a importância do movimento, a análise das falas das entrevistadas aponta que a construção individual e coletiva de cada uma teve o ato de se empoderar como uma grande base para todas as outras mobilizações as quais se empenharam. A coragem construída cotidianamente por meio dos laços políticos e amistosos possibilitou a elas uma nova forma de se posicionar no mundo.

É importante ter uma abordagem feminista que coloque essas questões da sexualidade com tanta força que eu acho que não é todo. E, enfim, eu acho que a marcha traz essas pautas mais polêmicas, assim... tipo: "Vai andar de sainha, sim!", "Vou ficar de peito de fora, sim!" E eu acho que isso é um aspecto muito importante que a marcha consegue trazer. (Millena)

Como princípio mesmo, foco muito na questão da autonomia do corpo, que eu acho que é a primeira e última fronteira para que os homens e a sociedade, em geral, entendam que a mulher é um ser autônomo, não é menor, não é melhor, e é um corpo que é esquadrinhado, controlado pela ciência, igreja, pelo estado, o tempo todo. Então, eu acho que ir para a rua e gritar isso, e aquele choque que muitas pessoas com a questão de vadia mesmo... Porque aí, falando da questão do corpo, eu sei que tem muitos problemas e muitas mulheres acabam sendo prostitutas, não porque desejassem aquilo desde que nasceram, que é muito o discurso contra, não é nenhum problema, é um trabalho como outro qualquer, vários trabalhos usam o corpo também, manicure. (Beatriz)

Podemos perceber que a construção da autonomia sobre si é uma das maneiras de empoderamento que a militância na Marcha das Vadias RJ 2015 possibilita. Esse movimento situa-se nas fronteiras entre gênero, sexualidade e as utilizações do corpo como vitrine. A formação de uma identidade de gênero e/ou de sexualidade está intrínseca a formação pedagógica de emancipação (ARROYO, 2014) que possibilita o reconhecimento do campo político como um espaço fundamental para que as formações de parcerias internas do movimento possam dar base para atuações individuais fora dele.

É importante frisar que o processo de marginalização - subalternização, assimetria ou negatividade no imaginário social - por características específicas [ou identitárias] de um conjunto de atores sociais, tem sido, muitas vezes, a força organizadora para determinados sujeitos se reconhecerem enquanto grupo que compartilha uma identidade e também uma situação social desfavorável, a exclusão do sistema de direitos de cidadania. Daí, não ser difícil perceber o porquê de muitos movimentos sociais pelas e nas diferenças estarem marcados pela 
indignação, assim como por conflitos, algumas vezes, com irrupção violenta. No entanto, em nossa tentativa analítica, estas identidades vêm se tornando, no contexto atual da sociedade brasileira, verdadeiras forças revolucionárias. (ANDRADE, 2015, p. 826)

A força revolucionária (ANDRADE, 2015) é utilizada, portanto, na Marcha das Vadias RJ, como forma de potencializar o alcance do feminismo propagandoo por meio do aumento da adesão de militantes e simpatizantes. No entanto, a formação de pedagogias de emancipação (ARROYO, 2014) no movimento não se resume à coexistência e construção de gêneros e sexualidades e o empoderamento sobre si pelos diferentes usos do corpo. A importância atribuída ao movimento pelas entrevistadas evidencia os limites e as possibilidades de se construir redes de contato e de militância entre mulheres com fins de potencializar a subversão das normas sociais vigentes nas estruturas sociais. Ainda existem muitas barreiras a serem superadas pelo movimento, assim como em outros espaços de atuação feminista, como veremos no capítulo seguinte. 


\section{Sobre as diferenças que desafiam o movimento}

Neste capítulo, o segundo tema-chave é apresentado e se descreve na relação entre a pedagogia não formal da Marcha das Vadias RJ e a temática da diferença. Assim, algumas das maneiras pelas quais as diferenças são vivenciadas e de que forma o diálogo entre elas desafia o movimento serão centrais. Para melhor compreensão do tema, não abordarei somente a edição de 2015 devido à conjuntura do ano - poucas militantes e algumas ausências - ser fruto de acontecimentos de anos pregressos.

Um movimento que se reivindica interseccional é um campo aberto para a entrada de diferentes identidades, não somente de gêneros, sexualidades e marcadores físicos como vimos no capítulo anterior, mas também de classes, raças, etnias, origens geográficas e pessoas com deficiência física, por exemplo. Dessa forma, a primeira parte do capítulo apresenta uma síntese de palavras sobre a importância da Marcha das Vadias RJ para cada entrevistada, que aponta suas visões pessoais acerca de sua militância coletiva e individual. Destas palavras, foi possível observar algumas das razões pelas quais a coexistência da diversidade e a promoção do diálogo ainda encontram desafios internos.

Expostos os desafios indicados pelas entrevistadas, Crenshaw (2002) e Hooks (2013) são fundamentais para compreender o conceito de interseccionalidade e a principal tensão da Marcha das Vadias RJ, que é o diálogo com as feministas negras. Por fim, o capítulo aborda sobre a formação de uma identidade feminina e feminista no seio do movimento, oriunda das pedagogias de emancipação (ARROYO, 2014).

Assim, entendo que as lutas contra o racismo, contra o sexismo, contra a homofobia, contra o capacitismo, contra o genocídio indígena, contra a intolerância religiosa, entre outras, não são meras reformas com pretensões periféricas para o funcionamento das sociedades contemporâneas. As lutas diferencialistas, lutas pelas e nas diferenças, são também resistências e reformas, mas querem algo mais, têm um horizonte de sentido que visa transformar profundamente a sociedade, pois movimentam forças estruturantes da vida social, tal como os gêneros, as sexualidades, as etnias, as gerações, as origens geográficas, as religiões e as capacidades humanas, entre outras (ANDRADE, 2015, p. 286) 


\section{1.}

\section{A academia e a militância: uma fronteira possível?}

$\mathrm{O}$ entendimento dos conceitos de gênero e de sexualidade, segundo as observações e entrevistas, era algo comum para a maioria das participantes da construção da Marcha das Vadias RJ 2015.

O debate que a Marcha propõe na rua e, consequentemente internamente, é um debate que fala tanto de gênero como de sexualidade. Em geral, pelo que eu tenho visto, uma das duas coisas é abandoar, é... menos enfatizada e a outra é mais enfatizada, né? Então, você tem movimento de mulheres que falam de gênero, mas não botam sexualidade, você tem movimentos de sexualidade mas não falam de gênero. Então, eu acho que a Marcha faz essa discussão... Junta bem as duas coisas, né, faz essa discussão... Enfim, eu acho que isso é interessante... Uma riqueza da Marcha. (Nathalia)

Como podemos ver na afirmação de Nathalia e também segundo Dutra e Nunes (2015), a entrada e a disseminação das discussões de gênero na academia foi proporcionada pela atuação de movimentos feministas ao longo da história que levaram inúmeras mulheres às universidades com suas bandeiras de luta. As discussões teóricas e políticas do conceito em espaços acadêmicos e de militância possuem sua importância estratégica para que a discussão dos temas que envolvem a vida das mulheres possam ser problematizados dentro de categorias como, por exemplo, dominação e reprodução, vistos sob a ótica do sistema patriarcal constituído em nossa sociedade.

Eu acho que você pode debater uma série de coisas na questão de gênero, tem coisas que realmente são complicadas das pessoas entenderem, não é? Por exemplo, pessoas que são gênero fluido ou pessoas que são bigênero, coisas assim que eu acho que o gênero, assim como a sexualidade, está num espectro, né? Então têm várias matizes aí, várias tonalidades. Então, eu entendo que as pessoas têm uma dificuldade muito grande de entender e de lidar com essas coisas que são mais cinzas, que não são muito definidas, que não são muito claras, assim, muito binárias, entendeu? (Antônia)

Porque desde pequenininha a gente é muito controlada. E eu sempre fui uma criança fora dos padrões binários de gênero feminino, assim, sempre gostei mais das brincadeiras chamadas de meninos. (Heloisa)

Eu acho que isso é importante. A desconstrução dos gêneros, eu acho que essas coisas fizeram mais sentido e me foram ensinadas. (Indianara)

Pude identificar que estas militantes, além de possuírem uma discussão acadêmica do conceito de gênero, também se percebem "membros de uma bolha" - expressão utilizada por Cláudia e Antônia em um de nossos encontros. Nesta bolha, estamos nós, acadêmicas e militantes que entendemos os conceitos, entre 
outros, de gênero, de violência simbólica (BOURDIEU, 1999) e do que é ser construída como um tipo de mulher e algumas maneiras nas quais podemos burlar isso e nos posicionarmos de outra forma.

O entendimento destes conceitos não se restringia somente a um discurso propagado nas entrevistas e ao longo da construção do movimento. Muitas se mostravam preocupadas em não reproduzir as práticas de dominação sobre outras pessoas. Ao compreender o conceito de violência simbólica, por exemplo, as opressões sofridas por muitas militantes no cotidiano ganhavam novas formas de debate e originavam novas formas de luta cotidiana. Segundo Bourdieu (1999), este tipo de violência parte da pré-definição de uma cultura arbitrária que institui um sistema igualmente autoritário no qual o status de dominação de uma classe sobre outra, de um gênero sobre outro, ou de uma pessoa sobre outra, é perpetuado por meio de mecanismos sutis. Estes, nem sempre são percebidos pelos seus receptores, de forma que naturalizam a dominação que lhes é imposta.

A violência simbólica se institui por intermédio da adesão que o dominado não pode deixar de conceder ao dominante (e, portanto, à dominação) quando ele não dispõe, para pensá-la e para se pensar, ou melhor, para pensar sua relação como ele, mais que de instrumentos de conhecimento que ambos têm em comum e que, não sendo mais que a forma incorporada da relação de dominação, fazem esta relação ser vista como natural; ou, em outros termos, quando os esquemas que ele põe em ação para se ver e se avaliar, ou para ver e avaliar os dominantes (elevado/baixo, masculino/feminino, branco/negro, etc.), resultam da incorporação de classificações, assim naturalizadas, de que seu ser social é produto. (BOURDIEU, 1999, p. 47)

Dentro desta compreensão, havia, por exemplo, muitas conversas nos encontros sobre mulheres que estavam em uma "relação abusiva". A relação abusiva, termo cada vez mais comum entre grupos feministas, refere-se a um tipo de vínculo afetivo entre casais, que se estabelece quando uma das pessoas é intencionalmente diminuída de forma constante e coagida a agir de maneira com a qual não concorda, causando-lhe grande sofrimento. Neste tipo de relação, a dependência que se estabelece pode fazer com que a vítima, isto é, a pessoa que está em posição de desvantagem, não consiga perceber formas de sair desta situação. As relações de dependência podem ser financeiras ou psicológicas, o que ocasiona frequentemente a ocorrência de situações de violência simbólica.

Nas observações realizadas, tais momentos de conversa e debate sobre relação abusiva tornavam-se sensíveis e delicados, pois, em muito casos, as pessoas sobre as quais discutíamos eram bem próximas de uma de nós. Assim, 
pude perceber que tais ocasiões formavam o que as entrevistadas costumam chamar de "espaço seguro", no qual a troca de informações e possibilidades de desconstrução poderia ocorrer sem que outras militantes fossem incluídas na conversa, protegendo assim aquelas que eram o alvo dos debates de possíveis situações de desconforto ou discriminação.

A concepção de "espaços seguros" para a Marcha das Vadias do Rio de Janeiro de 2015 refere-se aos momentos nos quais as presentes podem tirar dúvidas sobre aspectos da militância ou mesmo falar intimamente sobre si e não receber nenhum tipo de tratamento vexatório. Dois foram os exemplos da necessidade de se construir estes espaços. Primeiro, quando houve a necessidade de falar sobre as melhores formas de se atuar politicamente com homens em espaços majoritariamente femininos e, segundo, quando se conversou sobre as melhores formas de se auxiliar outras mulheres em relacionamentos abusivos.

Tais relações se estabelecem devido ao fato de a Marcha das Vadias do Rio de Janeiro ser um tipo de movimento social no qual a sua organização em redes horizontais - tanto virtuais, nos espaços da Internet, quanto presenciais no espaço urbano - possibilitam a criação de um companheirismo (CASTELLS, 2013). Um companheirismo não no sentido de comunidade, mas, conforme afirma Castells (2013), que implica em uma série de valores comuns gerando práticas também regulares no movimento, no qual o ponto de partida é a defesa do poder da união, isto é, a ideia de que "juntos somos fortes e conseguiremos" (CASTELLS, 2013, p. 53). No caso da Marcha das Vadias do Rio de Janeiro, este companheirismo se traduz na defesa da sororidade entre as militantes e as mulheres próximas ao movimento.

A maior presença de mulheres com nível superior e pós-graduação faz com que exista maior convergência e diálogo em diversos assuntos sobre gênero e sexualidade. Assim, a militância das entrevistadas era, em sua maioria, moldada em muitos pontos, pelo estilo acadêmico. Na roda de conversa, por exemplo, sobre "Corpos que fogem à norma" o debate possuiu um formato acadêmico ao mencionar e tratar dos tipos de corpos que são considerados externos aos padrões sociais e as consequências para eles, tais como o corpo gordo, o corpo trans e também os corpos e os gêneros que não se "alinham", isto é, quando as identidades de gênero não são compatíveis ao corpo biológico. A utilização e o entendimento dos conceitos de gênero e sexualidade, bem como a apresentação 
das e dos presentes no debate era marcado por citações teóricas e nomeação de autores conhecidos na abordagem do assunto, como Simone de Beauvoir, Judith Buttler e Joan Scott.

Outra questão referente à presença de um discurso acadêmico, apontada por uma das entrevistadas, é como um conflito interno. Em anos anteriores, segundo falas de quatro entrevistadas, a "presença acadêmica" de muitas das organizadoras era um dos fatores de silenciamento das "não acadêmicas".

Não havia bloqueio nas falas. Todo mundo tinha direito de falar, dizer que não, não é por aí. A coisa é que uma coisa é dizer que pode, outra é como o diálogo se dá. Então, eu acho que algumas mulheres tinham uma personalidade que se impunham mais. E até uma das meninas que eu coloquei, colocou que achou que isso tinha a ver com a inserção na academia e tal, "Ah, fulana tem mestrado", e aí você não sabe do que está falando e a pessoa não vai dizer que você não sabe do que está falando, a pessoa fala "não", mas isso é uma forma de você acabar silenciando aquelas que não têm inserção acadêmica, que não estudam o movimento feminista há anos, que não participam de movimento feminista há anos. Mas, não era, pelo menos na grande maioria das vezes, não era um silenciamento direto do direito de falar. A questão é que se você fala e recebe uma resposta que não é muito de "Você não sabe do que você está falando?", não dessa maneira, mas de uma maneira mais sutil, você não vai querer falar de novo. Você vai ficar sem graça. Então, acho que isso acabava acontecendo de uma maneira mais sutil, não de uma maneira muito explícita. (Millena)

Tem uma coisa também que, por exemplo, eu sempre falo que eu estando na marcha, e sendo tão popular, de não ser nem acadêmica nem nada, eu além de provocar muito, que eu acho que os meus papeis em todos os lugares que eu vou é sempre provocador. No segundo, ficar alertando os outros: "Não faça tese, quem tá lendo não vai entender, façam o mínimo possível para as pessoas se interessarem e entenderem", porque a grande briga da marcha é que todo ano o pessoal quer escrever teses, ou defender sua ideia com teses, e isso foi muito cansativo ano passado. (Virginia)

As possibilidades e limites do diálogo dentro do movimento aparecem como motivador de conflitos em anos anteriores. A reprodução de hierarquizações sociais também se mostra dentro do movimento, como um dos limites da horizontalidade deste tipo de organização.

\section{2.}

\section{Os desafios da horizontalidade como proposta}

Castells (2013) afirma que "movimentos em rede de redes" não necessitam de um centro identificável que viabilize as coordenações dele. Assim, não precisam de uma liderança formal e de uma organização vertical. As redes são estabelecidas fisicamente e também nos meios virtuais. Os contatos são contínuos 
e a chegada de pessoas é em fluxo constante. Esta horizontalidade de lideranças "é de fato o alicerce necessário para gerar confiança” (CASTELLS, 2013, p. 167).

A marcha é um movimento que busca horizontalidade. É um movimento que se pretende ser um movimento isolado. Então, assim, cada ano uma construção diferente na marcha, mas como você falou, há pessoas que estão lá desde a primeira construção e há pessoas que chegam, como eu cheguei no final de 2013 e há pessoas jovens de 17 anos e há pessoas mais velhas de 50, há pessoas que são acadêmicas de graduação, há pessoas que são doutoras, há pessoas que não são de universidades at all $^{33}$ e a gente acaba reproduzindo muito as hierarquias. Então, acaba tendo uma reprodução de que vozes se escutam mais, que vozes querem se impor mais também e quando isso é evidenciado por alguém do tipo: "Galera, não vamos construir essa hierarquização", isso mexe um pouco, do tipo: "Não vamos atropelar processos, a marcha é uma a cada ano". (Heloisa)

Assim, o próprio movimento evita que muitos valores sociais com os quais possui um embate penetrem no interior de sua organização. A militância mais dura, apontada por Heloisa, Cláudia, Antônia e Virgínia, bastante comuns em organizações partidárias, por exemplo, é evitada. Neste sentido, estrutura-se, a cada ano, um movimento mais leve e divertido, que propicia um ambiente de atração de novas pessoas e também motivador para a permanência de muitas delas como descreve Heloisa:

Esse ano eu ainda estou um pouco afastada, mas sempre foram muito divertidas as reuniões, tudo, sabe? Porque tem um afeto feminista ali que fica presente o tempo todo. Então, é um lugar de acolhimento, das pessoas falaram tranquilas. E a gente sempre depois das reuniões acabava em bar, não é?

A defesa da horizontalidade e o exercício da mesma também são entendidos pelas entrevistadas como um dos muitos limites e fonte de conflito interno da Marcha das Vadias RJ, tal como evidenciado na fala de Heloisa. Tais limitações também fazem parte das desconstruções cotidianas de forma que muitas delas evidenciam frequentes cuidados para evitar tais reproduções. Esta prerrogativa de horizontalidade torna-se um dos horizontes a ser atingido pelo movimento a cada edição.

No ano de 2015, esse tipo de conflito não ocorreu ou não pude percebê-los. Éramos poucas e todas "acadêmicas" ou bastante próximas do discurso acadêmico. A argumentação sobre o diálogo foi um dos marcadores em todas as atividades desta última edição, bem como das anteriores. Por meio de reuniões, rodas de conversa e oficinas, a Marcha das Vadias RJ evidencia que está inserida

33 A entrevistada se refere ao fato de que existem pessoas com diversos tipos de escolaridade dentro da Marcha das Vadias RJ, usando um jargão acadêmico. 
em uma sociedade de conflitos pelos quais a hierarquização das diferenças parte não somente da base da percepção de gênero sexualidade, mas que há diversos outros fatores a serem considerados, tais como raça, etnia, classe social, origem geográfica e pertencimento acadêmico, por exemplo.

A aposta no diálogo constante mostrou que todas as entrevistadas exerceram em inúmeras ocasiões a empatia para compreender outras opressões, muitas das quais não as vivenciavam, tomando pra si a luta de outras "companheiras", utilizando um termo bastante frequente delas. É importante destacar que este exercício de empatia não é acompanhado por exercer o protagonismo sobre a outra em sua bandeira de luta. Por exemplo, a participação de homens em movimentos feministas, segundo uma das defesas da Marcha das Vadias RJ 2015, não pressupõe que os homens possam falar no lugar das mulheres em situações nas quais elas falam por si mesmas.

A convocação para as reuniões de construção de edições da marcha, explicitada nos eventos criados no Facebook indicam de que maneira a participação de homens no movimento é permitida:

Quem pode chegar nessa reunião? Qualquer pessoa. Porém: - Mulheres cis, mulheres trans, homens trans e pessoas não binárias: a palavra é nossa.

- Homens cis: podem vir quietinhos pra ouvir sem dar pitaco, entendemos que assistir nossas reuniões pode ser um bom aprendizado pra vocês. (Nem pensem em fazer qualquer tipo de estudo/trabalho baseado nas nossas reuniões, isso não é permitido e vai dar ruim se tentar).

No entanto, no último ano, o perfil acadêmico apresentou transformações. As integrantes do movimento foram convidadas para debater sobre consentimento em uma escola pública de renome e, após tal experiência, mais de uma entrevistada demonstrou interesse em continuar desenvolvendo atividades que promovam a articulação entre movimentos sociais e a educação formal. Antônia foi ao evento convidada por estudantes e relatou em conversa no bate papo do Facebook, no qual estão presentes todas as pessoas que construíram a marcha das Vadias RJ de 2015, que foi muito bem recebida e que falou sobre consentimento para os jovens da escola. Avaliou de forma bastante positiva sua fala e também o interesse dos jovens que a ouviram.

Em sua última edição, a Marcha também contou com maior presença de estudantes secundaristas e mulheres muito jovens, sendo uma integrante da Marcha das Vadias RJ 2015 também bastante jovem. A atração que o movimento 
desperta tem alcançado diversas faixas etárias, uma vez que jovens mulheres despertam cada vez mais cedo para a temática do feminismo. Este interesse precoce pode estar relacionado com a adesão crescente de artistas e de personagens em destaque na mídia que começaram a abordar o feminismo.

Olha, eu acho que a presença da Internet e das redes sociais foi um salto. Eu acho que está rolando aí um feminismo 3.0, entendeu? Isso tem um lado muito bom que é as pessoas poderem trocar ideias, grupos do Facebook, no WatsApp. De uns anos pra cá surgiram vários sites, vários portais maravilhosos de... entendeu? Onde tem muita coisa. Quem se interessar pelo assunto tem muitas ferramentas hoje em dia, coisa que antigamente não tinha. Era uma coisa mais acadêmica ou você tem que ler livros inteiros. $\mathrm{E}$ hoje em dia você tem uma coisa mais fluida, mais rápida. Isso pra mim foi, acho que, na minha opinião, um grande salto. No ano passado, então, eu acho que a coisa explodiu. Você tem agora mulheres famosas, artistas pop levantando essa bandeira, que era uma coisa que muita gente achava que o movimento feminista estava meio morto. Antes de ter esse levante que está tendo agora. Algumas pessoas erradamente achando que não precisava mais, que as mulheres já alcançaram o que tinham que alcançar que é uma visão totalmente absurda. (Antonia)

Mesquita (2008) aponta que a crescente participação de jovens em movimentos sociais decorre do destaque que novos protagonistas têm obtido nas mídias e no campo do trabalho. A utilização das ferramentas de rede possibilitam conexões mais rápidas e de grupos que não necessitam estar próximo geograficamente para estabelecer conexões entre si. Um dos fatores que levam a maior adesão de jovens à Marcha das Vadias RJ é a utilização de redes sociais que transformam o discurso acadêmico em textos mais curtos e palatáveis a leituras rápidas com grande número de informações. A aposta da confecção e divulgação de artes gráficas (Figura 6) que misturem informações e imagens auxilia na viralização, isto é, maior propagação e de maneira instantânea de bandeiras de luta. 


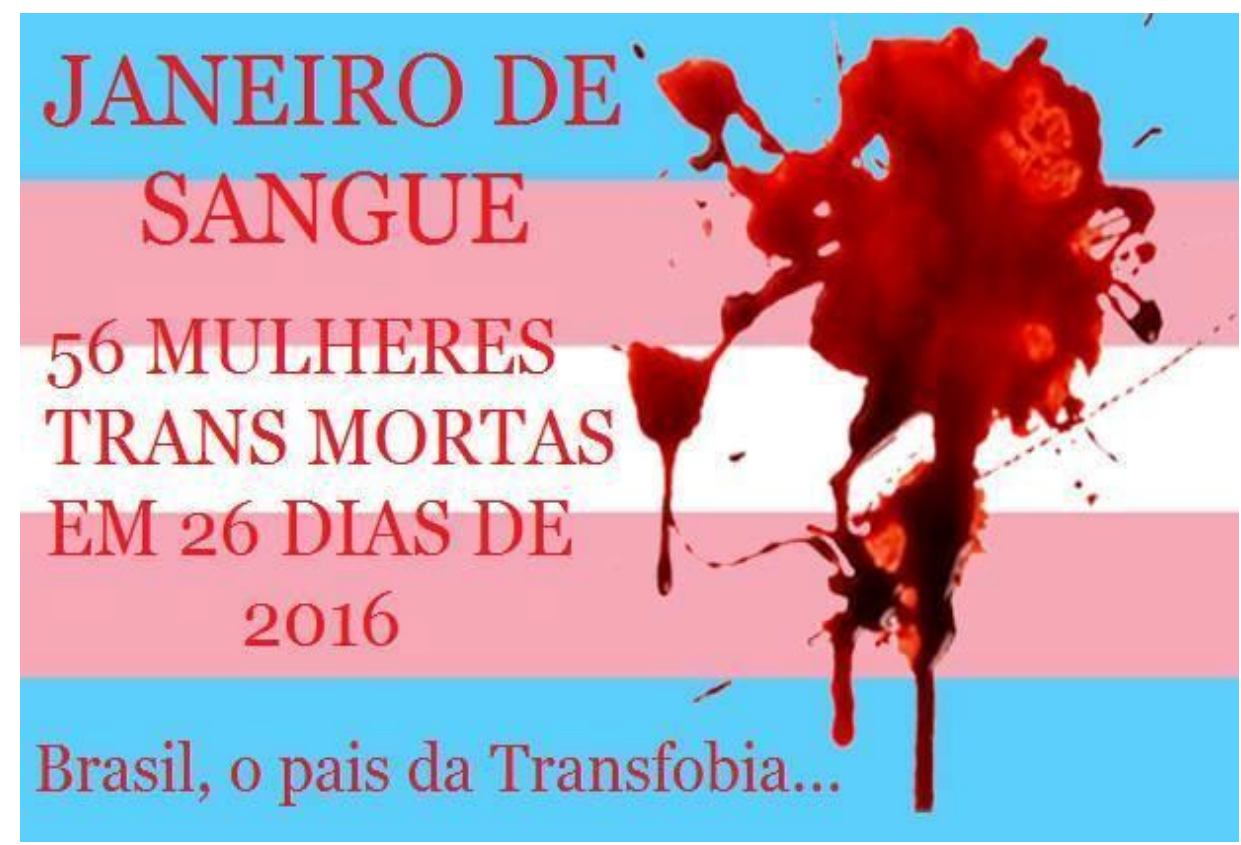

Figura 6: Exemplo de informações iconográficas.

Fonte: Página Marcha das Vadias Rio de Janeiro)

Segundo Andrade (2015, p. 829), entre as pautas de ação dos "novos movimentos sociais" estão: "chamar a atenção para as demandas identitárias específicas - como etnias, gêneros, sexualidades, religiões, capacidades e condições, gerações, origens geográficas, entre outras - sem abrir mão da concepção de dignidade humana compartilhada e irrenunciável" e também "inaugurar novas formas de organização, mobilização e protesto, com destaque para o uso das novas tecnologias de comunicação e para a convocação livre e descentralizada". Nestas perspectiva, podemos entender a Marcha das Vadias RJ 2015 como um novo protagonista de mudanças sociais, principalmente, nas temáticas de gênero e sexualidade.

No entanto, as críticas que a Marcha das Vadias RJ recebeu, ao longo de suas edições, de que se trata de um movimento de mulheres brancas e acadêmicas tem sido um dos motivadores para que as militantes tentem se aproximar de outros grupos e fazer com que outras impressões do movimento surjam. Uma frequente resposta a esse tipo de crítica é uma convocação para que todas as mulheres que se interessem passem a construir o movimento, assim o movimento passaria a ter também a marca de outras pessoas, incluindo as que o criticam.

Apesar de isso não ser algo que se busca em uma organização, a marcha acaba sendo pra mulheres brancas de classe média. O que também... É o que eu falei no início da entrevista, toda mulher é, ela vive em resistência. A sociedade não nos ensina que a sociedade nos controla. E então, fugir do controle é algo que toda 
mulher precisa em diferentes graus, em diferentes situações. Então, assim, a marcha é vista como... ela é acusada de ser um movimento branco de classe média, mas as mulheres brancas de classe média também resistem, né? Então, acho que acaba sendo mais pra esse público mesmo. (Heloisa)

A recepção a esta crítica nem sempre se dá do mesmo jeito, conforme explicitado na fala de Heloísa. No entanto, ao longo da construção de 2015 era nítida a vontade e a constante boa recepção das militantes a novas integrantes e uma abertura à escuta das críticas, com intencionalidade de fazer com que servissem de motivação para uma transformação do movimento e aumento da pluralidade interna dele.

Quem está de fora, sinto muito. Venham pra dentro e vejam por vocês mesmo se é isso ou se não é. Muita gente não está, não conhece a marcha, vê de longe e fala um monte de coisa. Eu diria que você pode falar um monte de coisa, mas pelo menos vem ver de perto. Depois que você vê de perto, fala o que você quiser. Falar de longe eu acho chato. (Antônia)

\section{3. \\ O movimento em três palavras: definição do campo}

Durante uma etapa da entrevistas, quando solicitadas, as militantes definiram a Marcha das Vadias do Rio de Janeiro em três palavras. Elas apresentaram várias argumentações para a escolha das mesmas e algumas trocaram as palavras escolhidas por termos que para elas faziam mais sentido quando resumidos em uma única expressão.

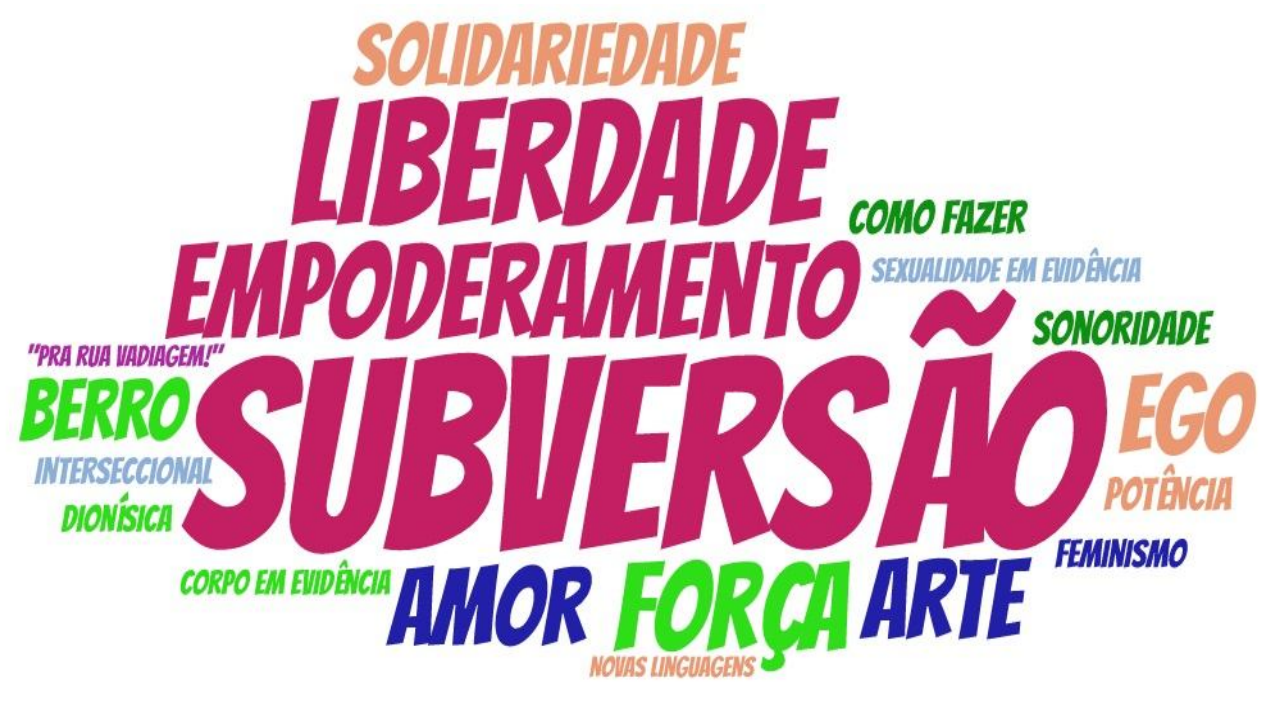

Figura 7: Definição da Marcha das Vadias 
A Figura 7 foi construída a partir do tratamento das respostas das entrevistadas ao responder a pergunta "Se você pudesse resumir a Marcha das Vadias em três palavras, quais palavras você diria? Por quê?". O tratamento consistiu em retirar os termos principais das respostas obtidas. Após seleção dos termos, estes foram lançados no programa Word Tagul Clods, no qual é possível selecionar o layout, cores, fontes e sugerir algumas diferenças nos tamanhos das fontes na apresentação da nuvem de palavras, tais como pode ser visualizado. Os termos "liberdade", "empoderamento" e "subversão" aparecem em maior tamanho que os demais devido ao fato de que foram citados duas vezes cada, enquanto que os demais foram citados somente uma única vez. Para que tal destaque pudesse ser melhor visualizado também optei por colocá-los da mesma cor. Os demais termos possuem cores aleatórias somente para facilitar a identificação de cada um, visto que alguns representam a junção de duas palavras tais como "Como fazer". Uma das entrevistadas definiu que a expressão "Pra rua vadiagem!" é o que caracteriza a Marcha das Vadias em três palavras.

As palavras em destaque e as justificativas para escolha de cada uma evidencia que estes termos não são vazios. Os termos evidenciam as identidades que sobrevivem a diferentes formas de opressão, preconceito e invisibilização. Vivenciam dentro do movimento, por conta dele e fora dele, choques culturais e identitários que ocasionam desconstruções pequenas e desestabilizadoras com as quais assumem uma nova postura frente ao poder institucional, político, cultural e pedagógico hegemônicos.

A Marcha em três palavras: força, liberdade e empoderamento.

E.: Por quê?

Porque ela justamente mostra a força de pessoas que vão pra rua e que cumprem realmente o papel de que fez a uma, fez a todas. Mesmo que em alguns momentos dê um distanciamento de algumas pessoas, mas acaba todo mundo voltando pra estar naquele dia. Então, ela tem essa força pra gente, mesmo após marcha. Empoderamento porque realmente empodera pessoas após marcha e as discussões também que acontecem anterior à marcha também acabam empoderando, formando redes. É muito engraçado... tem redes fora do Rio e isso é muito bom! E liberdade justamente por isso porque elas partem do mostrar nossos corpos, que portam seios (risos) e sabemos que eles não serão reprimidos nesse momento. E se houver repressão estamos ali também pra juntas, fortes e empoderadas, [para] ir juntas contra essa repressão. (Indianara)

A partir das palavras dispostas na imagem (Figura 7) podemos perceber as relações que os termos possuem com as análises já realizadas aqui sobre gêneros, 
sexualidades e a temática do corpo. Termos como "berro", "sonoridade", "dionísica" e "potência", por exemplo, evidenciam que o empoderamento, gerado a partir de pedagogias emancipatórias (ARROYO, 2014) dentro da Marcha das Vadias RJ é algo que transcende a subjetividade e que é, portanto, externalizado na marcha, enquanto culminância da construção de cada ano e também no cotidiano de cada militante.

Após observações das reuniões e participação dos debates internos e das rodas de conversa pude perceber que todas as entrevistadas foram em algum momento silenciadas e que havia, para cada uma delas, a necessidade de se colocar, de utilizar este empoderamento como força motriz de suas falas, de seus atos, de transgredir a invisibilidade a qual a sociedade delega para as mulheres. Tal necessidade se fez percebida quando, por exemplo, na reunião do dia 25 de junho, realizada no Instituto de Filosofia e Ciências Humanas da UFRJ (IFCS) Cláudia chamou atenção para este assunto. No mesmo momento em que nossa reunião se realizava, outra reunião para organizar uma manifestação no centro do Rio de Janeiro também ocorria. Em determinado momento, as pessoas presentes nesta outra reunião começaram a entoar palavras de ordem e Cláudia comenta que a percepção da predominância da voz masculina se fazia audível e o quanto achava que as mulheres ainda tinham que lutar para disputar estes espaços em "pé de igualdade".

As possibilidades de transgressões culturais do movimento ainda nos apontam que o feminismo, em suas diferentes roupagens, ainda é a luta pela sobrevivência das mulheres cis e trans. A necessidade de luta por sobrevivência exposta no destaque de Cláudia na reunião ou mesmo na percepção de que a maioria das palavras se refere à ocupação de diferentes formas do espaço público por estas mulheres. Embora tenhamos, atualmente, mulheres na política e que o mundo do trabalho tenha maior presença delas do que em décadas passadas, o espaço público ainda não se mostra seguro para nós. O debate sobre o corpo e a autonomia dos corpos que a Marcha das Vadias RJ aponta para essa não segurança e também para as diferentes interferências e violações que o corpo da mulher sofre cotidianamente. Em um país onde a maioria das pessoas acredita que 
uma mulher sair de casa de saia curta é um convite ao estupro ${ }^{34}$, o "berro", a "sonoridade", o "corpo em evidência" e a "força" se mostram fundamentais para garantir o empoderamento, uma formação pedagógica emancipatória (ARROYO, 2014), que auxilie na construção de pontes entre as mulheres e também na produção de meios para burlar assédios e intervenções de outras pessoas e do Estado.

As palavras dispostas na Figura 7 evidenciam não somente o significado que a Marcha das Vadias RJ possui para as entrevistadas, mas também refletem parte da luta histórica das mulheres para a conquista de direitos iguais. A importância atribuída ao movimento pelas entrevistadas e por simpatizantes da Marcha das Vadias RJ 2015 mostram que o feminismo ainda tem um longo caminho pela frente e que as formações "pedagógicas emancipatórias" (ARROYO, 2014) e que as "forças revolucionárias" (ANDRADE, 2015) dentro do movimento estão diretamente associadas a intervenções políticas em pequena e grande escala. $\mathrm{O}$ empoderamento, termo em destaque nas falas analisadas, pressupõe uma tomada de consciência de si, por meio da luta por autonomia do próprio corpo e da outra, por meio da interseccionalidade e das diferentes identidades de gênero e sexualidade que se manifestam na Marcha das Vadias RJ e fora dela.

Ainda sobre a imagem, podemos perceber que o termo "interseccional" só aparece uma vez. Talvez isso evidencie que a Marcha das Vadias RJ ainda se materializa como um movimento feminista que atende aos anseios das mulheres brancas. A interseccionalidade, conceito fundamental para articulação com as lutas das mulheres negras, ainda depende de outros termos que pouco aparecem nas falas das entrevistadas que construíram essa imagem.

O diálogo com o feminismo negro, embora a análise dos dados e a imersão no campo tenham demonstrado que existem tentativas de se estabelecer pontes e conexões, ainda se encontra limitado. Por meio das observações de reuniões e da percepção de determinadas ausências, principalmente de mulheres negras na construção da edição da Marcha das Vadias de 2015 foi possível perceber alguns dos avanços e das limitações que o movimento oferece para começarmos a tratar da relação entre a interseccionalidade e a diferença. Neste sentido, percebi certa

34 Ver pesquisa sobre o assunto em http://g1.globo.com/brasil/noticia/2014/03/para-585comportamento-feminino-influencia-estupros-diz-pesquisa.html 
contradição. O termo interseccionalidade aparece uma única vez, mas é uma das principais bandeiras do movimento e um conceito bastante falado nas entrevistas, ainda encontra suas limitações práticas e teóricas na rotina militante.

\section{4.}

\section{A interseccionalidade na prática militante}

A Marcha das Vadias é um movimento, mas assim, é um evento de feminismo interseccional. Então, a gente se preocupa com... a gente enxerga que todos os problemas são interligados. E isso é um aprendizado também, quando você está do outro lado, quando você está do lado do opressor. E, muitas das vezes, você está do lado do opressor. Eu sou uma mulher heterossexual, sou uma mulher cis gênero, sou uma mulher de classe média, né? Então, assim, existem as intersecções de raça, de classe, de gênero, da sexualidade. Então, assim, eu posso estar num lado do oprimido e ser opressora do outro lado. Isso é um aprendizado maior, que eu acho, que é desconstruir certas coisas. (Antônia)

A auto definição das militantes do movimento e a opção pela interseccionalidade é algo que esteve sempre em evidência, mas só apareceu uma vez como palavra que define o movimento. Na descrição do movimento Marcha das Vadias RJ em Blogs, eventos e páginas de Facebook, releases de jornais impressos e virtuais, em suas convocações de reuniões, na convocação para o dia da marcha e também nas falas das entrevistadas o termo sempre aparece.

Lembrando que: a marcha das vadias se propõe a ser um movimento feminista interseccional - vai ter trans, vai ter prostituta, vai ter conversa de classe, raça, local de origem, profissão e outros temas. (Convocação para a primeira reunião de organização da Marcha das Vadias RJ 2016)

A cor da pele não pode ser motivo de estupro!! O local de moradia não pode ser motivo de estupro!! A profissão não pode ser motivo de estupro!! A identidade de gênero não pode ser motivo de estupro!! A orientação sexual não pode ser motivo de estupro!! (Manifesto da Marcha das Vadias de 2014, disponível no $\mathrm{B} \log$ )

Segundo Crenshaw (2002), as bases para a construção do mesmo estão nas discussões sobre direitos humanos e nas diferentes maneiras que a desigualdade atinge as mulheres de todo o mundo.

Em nível formal, o princípio da igualdade de gênero, no que se refere à fruição dos direitos humanos, baseia-se na Carta das Nações Unidas e na Declaração Universal dos Direitos Humanos, sendo depois explicitado na Convenção para a Eliminação de Todas as Formas de Discriminação contra Mulheres (Convention for the Elimination of All Forms of Discriminantion Against Women/CEDAW). Essas 
garantias foram detalhadas através de uma série de conferências mundiais, incluindo as do Cairo ${ }^{35}$, de Viena ${ }^{36}$ e de Beijing ${ }^{37}$. (CRENSHAW, p. 171, 2002).

Tal movimentação em torno de conferências mundiais promovidas pela ONU se tornou necessária a partir da constatação de que o texto genérico da Declaração Universal os Direitos Humanos, que reflete muito mais a realidade masculina e sem a inclusão de debates sobre as desigualdades de gênero, mesmo que as declarações se posicionem formalmente a favor da atuação igualitária para ambos os gêneros. Tais debates buscam englobar ainda as discussões a respeito de raça e incorporar as opressões por gênero às de raça, compreendendo que as duas categorias não podem ser dissociadas dos debates e atuações no campo dos direitos humanos. O conceito de interseccionalidade é, neste sentido, oriundo da perspectiva de "acúmulos" de marcadores que podem fazer com que uma mulher possa sofrer em maior ou menor grau situações de pressão, dominação e invisibilização.

Assim como é verdadeiro o fato de que todas as mulheres estão, de algum modo, sujeitas ao peso da discriminação de gênero, também é verdade que outros fatores relacionados a suas identidades sociais, tais como classe, casta, raça, cor, etnia, religião, origem nacional e orientação sexual, são diferenças que fazem diferença na forma como vários grupos de mulheres vivenciam a discriminação. Tais elementos diferenciais podem criar problemas e vulnerabilidades exclusivos de subgrupos específicos de mulheres, ou que afetem desproporcionalmente apenas algumas mulheres. (CRENSHAW, p. 173, 2002).

A intersecionalidade sobrepõe, no movimento feminista, a ideia de "superinclusão" que pressupõe que um problema ou condição imposta de forma específica ou desproporcional a um grupo de mulheres é tratado como um problema de gênero, sem considerar as consequências do racismo, da desigualdade social, da lesbofobia. Em diversas situações, cabe analisar que determinadas mulheres, por possuírem certos marcadores identitários e sociais, estão mais propícias a determinadas situações de opressão que outras. Um exemplo disso é a questão do tráfico de mulheres, nas quais a maioria é negra e/ou de baixa renda, no qual determinados fatores contribuem na maior vulnerabilidade dessa mulheres.

35 Conferência Internacional Sobre População e Desenvolvimento, 1994.

36 Conferência de Direitos Humanos, 1993.

37 Conferência Mundial sobre as Mulheres: ação para igualdade, desenvolvimento e paz, 1995. 
Os esforços no sentido de remediar tais situações devem ser fundamentados em uma compreensão da magnitude do problema, incluindo, quando forem relevantes, suas dimensões raciais. Em algumas ocasiões é visível a atenção dada à identidade racial ou social de mulheres traficadas; no entanto, o reconhecimento das dimensões raciais do problema nem sempre é suficiente para garantir que as soluções propostas sejam absolutamente informadas por esses fatores. (CRENSHAW, p. 175, 2002).

Para que a luta defendida pela Marcha das Vadias RJ seja compreendida é importante perceber que um movimento intersecional coloca em primeiro plano, por exemplo, as questões de gênero e também as dimensões raciais, pois ambos são entendidos como fatores que contribuem para situações de subordinação. É importante destacar que raça e gênero não são os únicos fatores englobados nessa perspectiva teórica, mas também classe social, origem geográfica, etnias, as questões relativas à prostituição e também as demandas de pessoas trans.

Tudo que eu desconstruo, tudo que eu... Porque é o seguinte, é aquilo que eu falei. Você na rua, na interseccionalidade, muitas vezes, você está no papel de opressor, então, assim, eu me vejo como aliada da luta LGBT, por exemplo. (Antônia)

E o fato de conseguir falar das mulheres transexuais, sabe? Da prostituição também, porque eu acho que nem todo o feminismo consegue falar da prostituição também, porque é um tema muito polêmico. Então, eu acho que a marcha tem realmente essa força, de pegar todos esses pontos controversos e falar sobre eles. (Millena)

Na perspectiva de Antonia e Millena, Andrade (2015, p. 289) defende os novos movimentos sociais podem "sensibilizar e conscientizar os sujeitos em situação de privilégio social", tais como os homens, os brancos, os heterossexuais, os cristãos, as classes médias e altas, os cidadãos urbanos, sobre "a necessidade de parcerias ativas para a construção de uma cidadania ampla para todos e todas".

Internamente, as militantes encontram diversos problemas em estabelecer esse diálogo entre diferentes perspectivas de opressão na construção da marcha e na socialização política e pessoal. Assim, a interseccionalidade é um tema forte, mas também um grande desafio para a Marcha das Vadias do RJ, tal como tentarei explorar a seguir.

Antecedendo a primeira reunião da Marcha das Vadias RJ 2015, Antonia apresentou o relato de problemas na construção do ano anterior em relação à construção política com as feministas negras. E no decorrer da reunião, Isa levantou a crítica sobre as palavras de ordem com as quais se sentiu ofendida por considerar que eram capacitistas, conforme já apresentado no capítulo 2. A presença de prostitutas e pessoas trans na construção e na Marcha fazem com que 
suas bandeiras estejam sempre presentes nas discussões. Estas observações nos servem apenas para registrar o entrecruzamento de identidades de mulheres: mulher e negra; mulher e deficiente; mulher e prostituta; mulher e transgênero. Este é um desafio diário do movimento como um todo, visto que as diferenças geram uma necessidade da inclusão de todas dentro da luta da Marcha das Vadias RJ, tal como aponta a fala de Manuela sobre a construção da Marcha e do manifesto de 2014:

Tinha disputas também de protagonismos, eu lembro também que na época nós tínhamos a participação também de outros segmentos. Tinha as mulheres trans, as mulheres lésbicas que elas sempre... Também, pontuavam de que a Marcha também não dava voz para as mulheres lésbicas, sempre botava como se mulheres lésbicas... Como se a questão trans envolvesse todos e não é assim... E não é assim. Eu lembro que tinha duas militantes que sempre colocavam isso em todos os debates, em toda construção da Marcha, até no manifesto. (Manuela)

Observando e participando do campo pude perceber que as tentativas de conciliação são frequentes e que alguns temas se mostram mais conflituosos que outros, tais como as dificuldades de se estabelecer uma militância em conjunto com mulheres negras. A possibilidade, capacidade e predisposição intencional para a desconstrução individual e coletiva do movimento encontra um grande entrave nesta questão.

É, aí também, como lidar com as críticas do movimento de mulheres negras, né? Que também tem posições diferentes ali dentro... Tinha posições diferentes. Como debater, né? Em que termos debater feminismo antirracista? Isso é uma tensão também. Nem todo mundo tinha os mesmos posicionamentos. É claro que eu acho que todo mundo da Marcha tava muito interessado em ouvir as críticas, as mulheres negras e tentar construir um feminismo mais antirracista, mas isso pode ser feito... Tem vários graus e maneiras diferentes de fazer isso, né? Também isso gerava conflitos. (Nathalia)

A abordagem de Nathalia nos mostra que as dificuldades da militância conjunta entre mulheres brancas e negras na Marcha das Vadias passa pelo estabelecimento do diálogo entre elas. A dúvida que ela expõe sobre a possibilidade real da Marcha das Vadias RJ se tornar um movimento feminista mais próximo das lutas antirracista se torna concreta quando percebemos que o recorte de classe presente no movimento ainda é muito explícito. Embora as observações e diálogos com as militantes da construção da marcha do Rio de Janeiro de 2015 evidenciem a vontade delas em realizar esta ponte, as mulheres negras ainda demonstram não se sentir à vontade de militar neste espaço. 
Hooks (2013) apresenta uma discussão fundamental para compreender as dificuldades que ainda hoje regem essa parceria na militância. A autora é negra e escreve sobre os diálogos e os conflitos nas relações entre raça, capitalismo e gênero. Sua obra retrata vários casos nos quais as discriminações de gênero e raça se fizeram presentes na sua vida e como ela ressignificou tais opressões em suas aulas, a partir do pensamento freireano. As análises de hooks (2013) sobre o contexto norte americano e latino americano nos quais a escravidão fundamenta, ainda hoje, relações sociais pautadas no racismo nos auxiliam a compreender algumas das dificuldades enfrentadas pelo feminismo interseccional proposto pela Marcha das Vadias RJ.

Segundo a autora, é fundamental ter em mente as questões históricas que envolvem as relações entre mulheres brancas e negras. Dentro de uma perspectiva patriarcal, as relações raciais sexuais entre homens negros e mulheres brancas exemplifica a conquista da luta pela igualdade pública e privada na intimidade inter-racial. Embora tivessem pessoas que transgrediam essa fronteira, essa relação se tornou um tabu para a família patriarcal branca em todo o contexto americano. A autora afirma que tal debate ainda não se aprofunda na luta pelo fim do racismo. Tal ato rouba a atenção "da importância das relações sociais entre mulheres brancas e mulheres negras e de como esse contato determina e afeta as relações inter-raciais" (Hooks, 2013, p. 128).

As relações que se estabelecem entre as mulheres brancas e as negras são carregadas de experiências entre senhora e escrava. Mesmo que a abolição da escravidão seja uma realidade jurídica em nossa sociedade, os relatos históricos e as relações que se estabeleceram entre essas mulheres ao longo da história fazem com que não se torne possível, na maioria dos casos, uma relação igualitária e/o simétrica entre brancas e negras, segundo Hooks (2013). Enquanto na esfera privada se estabelecia esta relação de patroa e serva, na vida pública, somente o status de classe não era visto como suficiente para demarcar a superioridade reivindicada pelas mulheres brancas sobre as negras.

É importante demarcar que o patriarcado que rege a nossa sociedade é de supremacia branca e que como tal possui diferentes formas de controlar o corpo das mulheres. "Embora os homens, brancos e negros, se preocupassem antes de tudo em policiar os corpos de mulheres brancas ou ganhar acesso a eles, na realidade social onde as mulheres brancas viviam os homens brancos engajavam- 
se ativamente em relacionamentos sexuais com mulheres negras" (Hooks, 2013, p. 129). A autora afirma que para a maioria das mulheres brancas não se importava que estas relações se estabelecessem mediante coerção agressiva, estupro e outras formas de agressão sexual. Assim, em um contexto social onde o status da mulher branca era determinado pela natureza de sua relação com os homens brancos, a busca por estabelecer um distanciamento com as mulheres negras era essencial. "Assim, em certa medida, os privilégios de raça e classe das mulheres brancas eram reforçados pela manutenção de um sistema em que as negras eram objetos de sujeição e abuso por parte dos homens brancos" (Hooks, 2013, p. 131).

No caso brasileiro, a abolição da escravatura teve pouco impacto na relação entre brancas e negras. Hooks (2013) defende que a participação das mulheres brancas foi essencial para perpetuar estereótipos degradantes sobre a feminilidade negra, pois assim seu status seria mantido. As relações de trabalho livre e assalariado delegavam às negras o lugar de empregada que não possuía (e ainda não apresenta em muitas relações trabalhistas atuais) diferenças quanto ao tratamento destas mulheres em relação ao período de escravidão. A diferença principal foi, por muito tempo, o fato de que estas negras poderiam voltar pra casa no final do dia. "Para as brancas que consideram suas empregadas negras "como parte da família', sempre foi difícil entender que a empregada talvez entenda essa relação de maneira completamente diferente" (Hooks, 2013, p. 133).

Em uma relação de dominação também podem existir laços de carinho sem que isso altere a posição assimétrica e desigual de cada parte desta relação. Hooks (2013) reforça que toda essa conjuntura histórica não pode ser ignorada quando abordamos os entraves das relações entre brancas e negras, tal como pudemos perceber em nossas observações durante a construção da Marcha das Vadias 2015. Mesmo que as negras de hoje não tenham sido escravas, elas vivenciam relações desiguais e simétricas com as mulheres brancas.

$\mathrm{O}$ apelo feminista contemporâneo pela irmandade feminina, o apelo das brancas para que as mulheres negras e todas as mulheres de cor entrem no movimento feminista, é visto por muitas negras como mais uma expressão de negação. Por parte das mulheres brancas, da realidade de dominação racista, de sua cumplicidade na exploração e opressão das mulheres negras e dos negros em geral. Embora o apelo à irmandade feminina seja frequentemente motivado por um desejo sincero de transformar o presente, expressando a vontade das brancas de criar um novo contexto de vinculação, não há a tentativa de assimilar a história ou as barreiras que podem tornar essa vinculação difícil, se não impossível. (Hooks, 2013, p. 138) 
Este contexto histórico é um dos pontos de debates internos que não permitem que as feministas negras ressignifiquem o termo "vadias" do nome do movimento e que também não queiram militar no mesmo espaço. Em conversa com mulheres negras e perguntando sobre sua opinião sobre a Marcha das Vadias do Rio de Janeiro, percebi que muitas delas não querem estar neste movimento e em nenhuma outra edição do movimento Marcha das Vadias, pois compreendem que os privilégios da branquitude, isto é, os privilégios sociais que as mulheres brancas possuem só por serem brancas não serão facilmente contestados e deixados de lado pelas feministas brancas. Tais percepções, obtidas fora dos espaços de atuação da Marcha das Vadias RJ, confirmam-se em falas das entrevistadas que abordam a não presença de negras na construção.

$\mathrm{Eu}$ acho que as feministas brancas precisam ouvir. Nunca fizeram esse exercício, de escuta, de crítica, de tentar desconstruir privilégio e apoiar a luta das pretas, falo tomando uma categoria nativa delas. Precisa abaixar a cabeça, saber ouvir. Cara, eu acho que feminista branca tem que ter essa postura, deveria ter essa postura, tentar apoiar e construir junto. Porém, se as pretas, aí falando como o movimento negro como um todo, quiser radicalizar e na contraposição à maioria branca, não fechar, fizer um movimento, chegar a algo quase como nos EUA, em que o movimento é bem autônomo, forte, ás vezes, chegando à radicalidade, não aceitando apoio branco, nem politicamente, eu acho isso super legitimo, se isso acontecer acho super legitimo, sabe? Assim, eu gostaria de estar nessa luta e apoiar, mas se disserem "não", é isso, eu acho que faz parte, acho que a diáspora africana, o holocausto de toda uma raça, uma cultura, uma etnia, ele justifica essa postura. (Beatriz)

A crítica de mulheres negras ao movimento, bem como a fala de Beatriz e demais conversas realizadas sobre o assunto dentro do tempo no qual estive construindo e pesquisando a Marcha das Vadias do Rio de Janeiro 2015, apontam que o diálogo entre estes dois grupos de torna possível a partir do momento em que as feministas brancas se permitirem uma desconstrução profunda sobre as demandas das mulheres negras a partir da crítica delas. A desconstrução pressupõe perceber o nosso lugar de fala (aqui me coloco como uma mulher cis branca e acadêmica tratando sobre o assunto) privilegiado historicamente em detrimento das negras.

Se a leitura e análise da definição de importância do movimento Marcha das Vadias (Figura 7) evidencia que as mulheres brancas buscam ser ouvidas e que suas demandas sejam atendidas, as mulheres negras estão em posição ainda mais subalterna que as brancas em nossa sociedade. Perceber isso é tomar consciência que o feminismo branco conseguiu avanços ao longo da história e que tais 
avanços não foram garantidos na mesma medida para as mulheres negras. $\mathrm{O}$ percurso histórico dos dois grupos (brancas e negras) não precisa ser analisado de forma dicotômica, mas precisa ser percebido de forma desigual e assimétrico, pois assim ele foi tratado por nossa sociedade patriarcal.

Por outro lado, às negras é necessário tempo para assimilar que tais desconstruções são demoradas e que existem diversas tentativas de avanços com os quais podem valorizar uma militância em conjunto, sem que isso pressuponha sua invisibilização e silenciamento (ANDRADE; CÂMARA, 2015). No entanto, para tal, a participação de mulheres negras nessa caminhada é fundamental para que os processos de diálogo sejam potencializados de forma a obter maior alcance, mesmo que suas metodologias pedagógicas sejam de confronto.

Tiveram vários debates, o primeiro que eu fui em 2012 foi sobre prostituição. Aí, Indianara tava na mesa, o Jean Wyllys e uma socióloga. Assim, foi um debate super bom, assim sabe, por que a gente sempre vê, escuta falar assim sobre prostituição, mas, a gente nunca ouvia uma profissional do sexo falando sobre isso, o que ela achava sobre isso. A gente sempre quer falar sobre o outro, se colocar que é uma profissão degradante e nenhuma mulher deve exercer, mas sem saber a opinião dessas mulheres e, aí neste dia, não só Indianara, como outras profissionais do sexo falando e tal e foi muito enriquecedor. (Manuela)

A perspectiva de que a luta das prostitutas é demarcada por questões políticas (SOUSA, 2011, p. 3) faz parte da percepção da Marcha das Vadias RJ em relação à sobrevivência e luta por reconhecimento e melhores condições de trabalho destas mulheres. A vivência de Indianara é colocada por ela mesma em debates e reuniões, tal como relatado por Manuela, de forma que a luta do movimento de prostitutas também passa a fazer parte do feminismo que o movimento se propõe.

Outras questões debatidas no seio do movimento tratam das temáticas relacionadas à maternidade. Os questionamentos sobre a maternidade e suas relações materializam opressões e cobranças ao feminino e evidenciam uma forma a mais de controle social do corpo das mulheres. A centralização do papel de gestar vida e de ser responsável pelo bem estar da criança (ALVES, 2012) faz com que muitas mulheres se sintam na obrigação social de exercer a maternidade e que outras tantas que optaram por ser mãe estejam em constante vigilância sobre a forma pela qual desempenha seu papel.

Mas, eu acho que o me fez mudar mesmo foi a maternidade, quando eu fiquei grávida. Eu passei por várias situações, até mesmo dentro da faculdade, com a minha família e aí que eu vi quanto isso pesava quanto mulher e aí eu fiquei 
grávida de mulher também. (...) Teve uma roda de conversa perfeita que foi feita (...) pra falar de mulheres feministas mães que, às vezes, também dentro do próprio feminismo a questão da maternidade fica invisibilizada. (Manuela)

Na Marcha das Vadias RJ 2015, a pesquisa participante (DEMO, 2008) permitiu perceber que muitas das entrevistadas se mostrassem abertas a esse diálogo, das formas em que ele se torna possível visando um avanço na luta em parceria. Tratando-se, especificamente, dos diálogos possíveis com as pessoas trans, as prostitutas e as pessoas com deficiência física, a presença destas pessoas faz com que as demandas delas estejam sempre presentes e em destaque nas discussões.

E.: Como você usa a Marcha dentro da sala de aula?

Como um movimento social, como forma de debater a questão da sociedade patriarcal e machista, diferença de gêneros, luta por direitos, e é muito bonito debater essas questões em sala de aula sabendo-se parte daquilo. (Cláudia)

Eu acho que ela tem razão, porque muitas coisas que eu engolia em almoços familiares, ou no trabalho, por conta de "não posso ferir essas sensibilidades porque, afinal, vou encontrar sempre com essas pessoas". Essas coisas não tão passando mais, porque elas ferem a mim, a sensibilidade fere, fere a sensibilidade de outras pessoas. Aí, to num exercício também, porque, na Marcha, eu falei em berro, eu vou para a rua e grito, tudo também é um exercício para mim muito difícil. Eu venho de uma família barraqueira, que nas brigas os vizinhos chamavam a polícia, família de favelado. É muito difícil. Caraca! É muito difícil! Falar essas coisas e se contrapor a discursos hegemônicos machistas, racistas, em uma família com $75 \%$ de negro e que tem racismo também entre os negros, pois é estrutural. Às vezes, nem se para conscientemente para pensar no que você está fazendo, porque machismo é estrutural, racismo é estrutural. Aí, assim, muito a contragosto, me contrapor a esses discursos hegemônicos, rindo, com ironia, e não berrando na cara da pessoa. Mas, olha, é um exercício para uma vida, que eu tenho muita dificuldade com o diálogo. Não peça para ficar calma, pedir para ficar calma é a mesma coisa de evocar todos os demônios, é isso. (Beatriz)

Eu acho que é isso, a gente aprender a entender mais o outro, que aquilo que não te afeta você não pode também ser contra quando o outro está exigindo um direito sobre aquilo que afeta ao outro e não a você. Então, você tem que aprender a se colocar no teu lugar e sair e deixar o protagonismo porque aquele momento não é seu. Acho que isso é muito importante. (Indianara)

As falas de Cláudia e Beatriz exemplificam as falas de todas as entrevistadas que aprendem muito no movimento e de que forma elas levam esses aprendizados para fora deste espaço. Enquanto que a fala de Indianara aborda o aprendizado de questões que não fazem parte de sua rotina e vivência, mas que aprende a respeitar e aderir em sua militância, sem retirar, no entanto, o protagonismo de lutas identitárias específicas de outrem. 


\section{5 Aprender a ser "vadia"? Das falas e testemunhos militantes}

Em que processos aprenderam a resistir à opressão, à segregação e negação dos seus direitos mais básicos? Com que pedagogias aprenderam a se organizar, lutar por direitos tão tensos como direito à terra, ao solo, ao teto, à escola? (ARROYO, 2014, p. 10).

Sobre os novos movimentos sociais pelas e nas diferenças e as relações com o campo educacional, Andrade (2015, p. 830) se pergunta: “constituem espaços de formação de novos sujeitos, de construção da cidadania e da defesa dos direitos humanos e das diferentes identidades? São meramente reativos ou são também propositivos? Funcionam no binarismo ação-reação ou são protagonistas de seus horizontes de sentido?".

Os questionamentos de Arroyo (2014) e Andrade (2015) são pontos de partida para a discussão desta temática. O capítulo tem, portanto, a finalidade de apresentar o terceiro tema-chave desta pesquisa, ou seja, a Marcha das Vadias do RJ 2015 como um espaço de formação pedagógica não formal (LIBÂNEO, 2007). Assim, num primeiro momento, tratarei de apresentar sinteticamente o que vem a ser a identidade vadia, oriunda dos processos internos e externos do movimento. Em seguida, para que esta identidade se torne possível dentro do movimento, mostrarei como suas militantes optam pela confecção de um movimento em redes tanto internas, quanto com outros movimentos e com pessoas que não constroem a Marcha das Vadias do Rio de Janeiro, mas que estão próximas a ela. E, por fim, o capítulo aponta quais são os espaços que, oriundos destas redes e das formações militantes, que as entrevistadas apontaram como frutíferos para a confluência de pedagogias emancipatórias (ARROYO, 2014).

As análises realizadas até o momento apontam diferentes formas pelas quais espaços educativos não formais, como é o caso do movimento feminista, contribuem para uma formação individual e coletiva que prioriza as formações culturais. $\mathrm{O}$ entendimento de cultura política, oriunda de teorias que introduziram os aspectos culturais nas análises sobre a nossa sociedade, construída a partir da 
infraestrutura social tornou-se uma importante chave de análise para a compreensão destas formações pedagógicas.

Isso é um aprendizado maior, que eu acho, que é desconstruir certas coisas. (...) E dentro da militância e isso pra mim é o maior aprendizado de todos, é você desconstruir certas coisas. É você... é aquilo que eu estava falando, às vezes, também é estressante, nem sempre é agradável porque desconstruir não é uma coisa divertida (risos). (Antônia)

Acho que ensina e é intencional, é um movimento social que luta por uma agenda específica, a feminista, então ensina a ter uma perspectiva feminina do mundo. “Como isso vai acontecer? Qual a metodologia?" São questões de construção coletiva. (Cláudia)

Um dos pontos mais significativos dos movimentos sociais é a tomada de consciência política que torna revolucionário o tempo de atuação deles. As militantes entrevistadas são vítimas que resistem a um processo que almeja decretar a inexistência delas e mantê-las na subalternização (ARROYO, 2014).

Gohn (2011b) nos apresenta um importante panorama para tratar do conceito de cultura política. Segundo a autora, o termo voltou a ter centralidade nas áreas de ciências sociais e políticas nos últimos dez anos devido à importância que a cultura passou a desempenhar nas análises que buscam explicações para atuações humanas. Partindo da teoria de que as atitudes humanas não são somente herdadas, mas também apreendidas, a educação ganha centralidade. Assim a opção por fazer parte de uma militância política passa a estar inserida em um contexto educacional gerado a partir da formação cultural e a construção de novas identidades.

\section{1}

Identidade vadia, aprendida e ensinada.

A percepção de que vivemos em uma sociedade multicultural, na qual as relações de poder desiguais determinam posições e papéis subalternos, é compreendida pelas militantes do movimento, tais como evidenciaram algumas falas ao longo desta pesquisa. No entanto, é o próprio movimento que optou por incluir tantas identidades em seu interior. As pedagogias emancipatórias da Marcha das Vadias RJ perpassam pelo diálogo e constantes tentativas do estabelecimento deste nas lutas cotidianas contra as opressões sociais. Nesta perspectiva, busco interlocução com o conceito de multiculturalismo (ANDRADE, 2009), que parte da coexistência de diversas culturas dentro de um 
mesmo contexto, na qual o diálogo é uma importante ferramenta para a valorização das diferenças.

Aprendi a dialogar com pessoas completamente diferentes de mim, apesar de achar importante construir com iguais. No espaço da Marcha, aprendi a conviver com algumas dessas diferenças, como coisas que eu gostaria de ser, coisas que jamais fui e tenho aversão completa, e mesmo assim existia o diálogo. (Cláudia)

Se ensina a conhecer as nossas especificidades, né? Apesar de sermos mulheres que não são iguais, a gente consegue o diálogo, a gente consegue um consenso, né? Tanto consegue que no final tem a experiência do ano, né? (Manuela)

As diferenças com as quais o movimento se articula a cada edição da marcha variam porque os marcadores identitários que surgem a cada ano nas militantes pode ser cada vez mais múltiplo. Woodward (2014) afirma que a construção da identidade é tanto simbólica quanto social. Assim, o apelo aos antecedentes históricos é importante para a auto-identificação destas militantes e é também uma importante fonte de conflito entre elas, especificamente no caso das feministas negras. O diálogo interseccional do movimento passa por estas questões, bem como a formação de bandeiras específicas de cada mulher dentro dele para formar seus protagonismos internos de luta e fazer com que estes sejam tidos como bandeiras coletivas.

A identidade se insere na cultura e se relaciona diretamente com o conceito de diferença, que envolve as formas como estas diferenças são representadas, pois cada sujeito é colocado em uma posição cultural, de acordo com a forma na qual é representado. Por exemplo, em nossa cultura patriarcal, machista, homofóbica, lesbofóbica e transfóbica, socialmente as mulheres estão abaixo dos homens, as mulheres negras abaixo das mulheres brancas, as pessoas trans estão abaixo das pessoas cis e assim por diante, fazendo com que diferentes formas de opressão passem a fazer parte da rotina de cada pessoa, segundo a identidade a qual reivindica e à qual é socialmente identificada. Somado a estas disposições binárias temos que uma mulher trans pode ser negra, morar na periferia da cidade e ser de classe social mais baixa, o que influencia diretamente nas formas de opressão pelas quais a sociedade vai subjugá-la diariamente.

A identidade marca o encontro de nosso passado com as relações sociais, culturais e econômicas nas quais vivemos agora (...) a identidade é a interseção de nossas vidas cotidianas com as relações econômicas e políticas de subordinação e dominação. (RUTHERFORD, 1990, p. 19-20 apud WOODWARD, 2014, p. 19) 
$\mathrm{O}$ direito à diferença e o reconhecimento dela ainda são barreiras do multiculturalismo (ANDRADE, 2009), da educação formal e também estão presentes nos espaços de educação não formais, como é o caso evidenciado nesta pesquisa.

Os movimentos sociais pelas e nas diferenças ressignificam a posição dos sujeitos subalternizados diante daqueles que querem eliminá-los. Ao afirmarem-se contra sua negação, afiançam o direito de ser o que são e negam ao intolerante a tentativa de eliminá-los. (ANDRADE, 2015).

As críticas externas à Marcha das Vadias do Rio de Janeiro é a de que se constrói como um movimento de mulheres brancas e burguesas e que sempre centram as suas reuniões e a própria marcha em si mesma e na Zona Sul da cidade, o que dificulta que mulheres da periferia estejam presentes na construção, por exemplo. Tais críticas são de conhecimento das militantes e as mobilizam a levar a marcha para outros lugares e fazer reuniões em horários acessíveis. $\mathrm{Na}$ última edição, logo na primeira reunião, uma das entrevistadas propôs que a marcha ocorresse no centro do Rio. Realizamos até uma reunião somente para avaliar a viabilidade desta construção, mas não havia locais com acessibilidade (pensando nas pessoas cadeirantes) e havia o risco de menor destaque ao evento, devido ao fato de que esta região nos finais de semana não possuía muito movimento ${ }^{38}$, o que também seria um fator de risco para todas as mulheres que se dispusessem a ir. É perceptível que as críticas são apreendidas de formas diferentes pelas entrevistadas, mas que enquanto um movimento elas viabilizam para que tais críticas sejam atendidas e/ou minimizadas visando a melhor horizontalidade possível.

E outra coisa, se você entra na militância pra ser querida por todos você vai se decepcionar muito, porque eu acho que faz parte de ser militante incomodar os outros. Eu acho que você entrou na militância pra incomodar e não pra ser amada. Obviamente, quando vem críticas de mulheres que são feministas também, que são militantes também, a gente debate, a gente conversa, mas, assim, ninguém vai ser unanimidade, não é? (Antônia)

Mesmo diante das críticas, a Marcha das Vadias RJ é um movimento que atraiu muitas das entrevistadas que não estavam na construção da primeira marcha. Por se mostrar um movimento receptivo as demandas das entrevistadas antes mesmo que elas passassem a militar neste espaço, como foi o caso de Isa

38 Atualmente a região é foco de turismo devido às intervenções urbanas sofridas por conta da realização das olimpíadas na cidade do Rio de Janeiro. 
que em sua primeira marcha sensibilizou o movimento para outras questões, como o capacitismo em seu ápice, isto é, no momento em que estava nas ruas.

Eu nunca tinha ido a um protesto. E eu lembro muito bem que foi dia 17 de julho. Tava um frio. Dia 07 foi meu aniversário, fiz 17 anos naquele ano... dia 17 dez dias depois do meu aniversário (...) e fui escondida da minha mãe, mas nossa eu acho que eu nunca me senti tão dona de mim, sabe, que nem naquele dia. (...) A Marcha inteira gritando e só tinha tipo eu de cadeirante, sabe. Eu olhei e falei, "Caralho! por minha causa, velho!” (Isa)

Isa é a entrevistada mais jovem que construiu a Marcha das Vadias RJ 2015. Destaco ainda que a perspectiva de militância liberal que valoriza a liberdade individual e a liberdade dos corpos não explica por si só a construção e eclosão do movimento, pois a atuação coletiva, que valoriza e luta por grupos de pessoas, classes sociais e afins possui grande destaque nele. Devido a esta mistura de formas de fazer política, de bandeiras e de identidades, o movimento origina e comporta diversas formas de militância em seu interior, como é o caso do anarcofeminismo $^{39}$, por exemplo. Cláudia defende a atuação do movimento, mas também busca propor suas militâncias próprias nele.

Eu acredito que a gente vai construindo coisas diariamente com quem está por perto. Cozinhar com as minhas amigas, construir espaços de autodefesa, etc. é muito mais interessante, é a construção do feminismo num microespaço. (...) Acho que eu ensino a ação direta, naquela perspectiva anarquista de faça-você-mesmo, preservar essa ideia de autonomia. (Cláudia)

Ao longo da pesquisa, percebi que a construção e eclosão do movimento dependem unicamente dessas militantes e da emoção delas em torná-lo real a cada edição. Após a primeira roda de conversa, realizamos uma confraternização, o Isoporzinho, onde o aprendizado com a prática se materializou em diversos momentos. Por exemplo, a montagem e a manutenção da estrutura para o evento, com aquisição de equipamentos antecipadamente. Durante o evento, três mulheres se uniram para trocar a bateria do equipamento de som sem nunca terem feito nada parecido antes. Antônia, que já havia sido entrevistada nesta ocasião, deixou registrado neste momento que ela aprende muito com a Marcha das Vadias RJ, mas que aprendia, principalmente, o "aprender a fazer", pois nunca havia tocado uma bateria antes. "Estou me sentindo super empoderada de conseguir fazer isso. Se não fosse a Marcha eu acho que nunca faria" (Antônia).

39 Perspectiva de luta feminista pautada em ideias no anarquismo, ou seja, na autoorganização exacerbada e em ações em auxílio institucional, mesmo que possam ter alcance menor. 
Os movimentos sociais clássicos - que possuem lideranças, bases, demandas, opositores, e afins - alteraram seus modelos e se materializaram em outros tipos, dos quais Gohn (2014, p. 60) denomina de "novos movimentos sociais". Segundo a autora, esses novos movimentos tem pautado as suas agendas de lutas sociais a partir de novas demandas, matrizes organizativas e diferentes formas de se comunicar e de agir. Novos sujeitos sociopolíticos surgiram desse processo (GOHN, 2014, p. 11). Característica importante desses novos movimentos sociais, a luta por direitos não engloba todas as questões. As reivindicações identitárias passaram e ter grande importância e, portanto, não poderiam ser secundarizadas na Marcha das Vadias RJ.

A organização em rede (CASTELLS, 2013; 2015) e a importância dada a sua socialização política (MESQUITA, 2003; 2006; 2008) interna apresentam aspectos importantes para a compreensão de diferentes possibilidades nas quais a temática da valorização das diferenças pode estar presente. Assim, como a observação participante no movimento e a análise dos dados indicam, a Marcha das Vadias RJ 2015 apresenta ser um espaço no qual as tensões e conflitos buscam não serem invisibilizados, e que, na maioria dos casos, repercutiu de forma positiva nas entrevistadas quando, por exemplo, sensibilizou para outras questões fazendo com que diversas bandeiras passassem a ser suas também, modificando as suas relações interpessoais em seu cotidiano fora da militância, de forma que outras pessoas foram afetadas por meio do diálogo.

A perspectiva de que a Marcha das Vadias RJ é um movimento divertido e que se organiza de forma diferenciada de outros movimentos sociais não se aplica nos momentos de desconstrução que alertam para os momentos em que as próprias militantes ocupam lugar de opressoras. Tais momentos se evidenciam quando, por exemplo, as entrevistadas percebem que podem ser tanto oprimidas pela sociedade quanto opressoras de outras mulheres. A partir da pesquisa participante (DEMO, 2008) pude perceber que esses momentos também foram meus quando, por exemplo, me atentei às diferenças existentes para que se viabilize a militância presencial de uma pessoa cadeirante. O testemunho das entrevistadas e a observação do campo propiciaram a percepção de que este movimento social, e não somente nele, as relações de ensino aprendizagem que se estabelecem são predominantemente autônomas e freireanas. Exemplos disso podem ser percebidos no relato ocorrido no isoporzinho ( 22 de agosto) no qual ao 
realizarmos a troca da bateria do equipamento de som, Antônia fala que nunca tinha feito aquilo e que por conta da militância na Marcha, aprendeu fazendo. Ou mesmo a fala de Heloisa que evidencia a importância do aprendizado das relações horizontais: "Eu aprendi a construção de processos coletivos que buscam a horizontalidade, a gente aprende ali as facilidades e os entraves disso".

O respeito aos saberes de outras militantes, a corporeificação das palavras também pelo exemplo, a aceitação do novo, a rejeição de diferentes formas de discriminação, as excessivas reflexões críticas sobre suas práticas (FREIRE, 1996) são algumas das atitudes presentes nas pedagogias da emancipação (ARROYO, 2003; 2014) da Marcha das Vadias RJ.

A pesquisa participante (DEMO, 2008) parte da concepção de que pesquisador e pesquisa não são polos opostos que não se relacionam. Nesse sentido, é importante afirmar que a identidade da Marcha das Vadias RJ 2015 também foi formada por minha pesquisa e presença no movimento. A Marcha das Vadias RJ possui uma identidade plural, que reafirma a interseccionalidade por se tratar de um movimento de prostitutas, de gays, de lésbicas, de mulheres cis que são oprimidas, de mulheres que sofrem preconceito e enfrentam dificuldades por ser mãe, por ter, mesmo que em presença menor, a presença de mulheres negras e periféricas também.

É importante demarcar que a luta feminista da Marcha das Vadias do Rio de Janeiro se propõe a repensar todos os tipos de opressões presentes em nossa sociedade, sob uma ótica feminista e feminina, tendo a ideia de que a visão de uma mulher analisa a conjuntura e atua sobre ela. A possibilidade de que o feminismo possa trazer outras reflexões teóricas sobre os problemas sociais vivenciados diante da globalização, do neoliberalismo e das crises econômicas e políticas sucessivas é uma grande aposta das entrevistadas.

A identidade coletiva do movimento passa, hoje, pelas lutas já demarcadas, mas também pela tomada de consciência individual e coletiva do papel desempenhado pelo Estado, que por meio de políticas públicas, legislação e participação política de indivíduos que possuem uma atuação política conservadora (Figura 8) gera novas formas de controle sobre a mulher e sobre todas as pessoas que estão à margem da sociedade. 


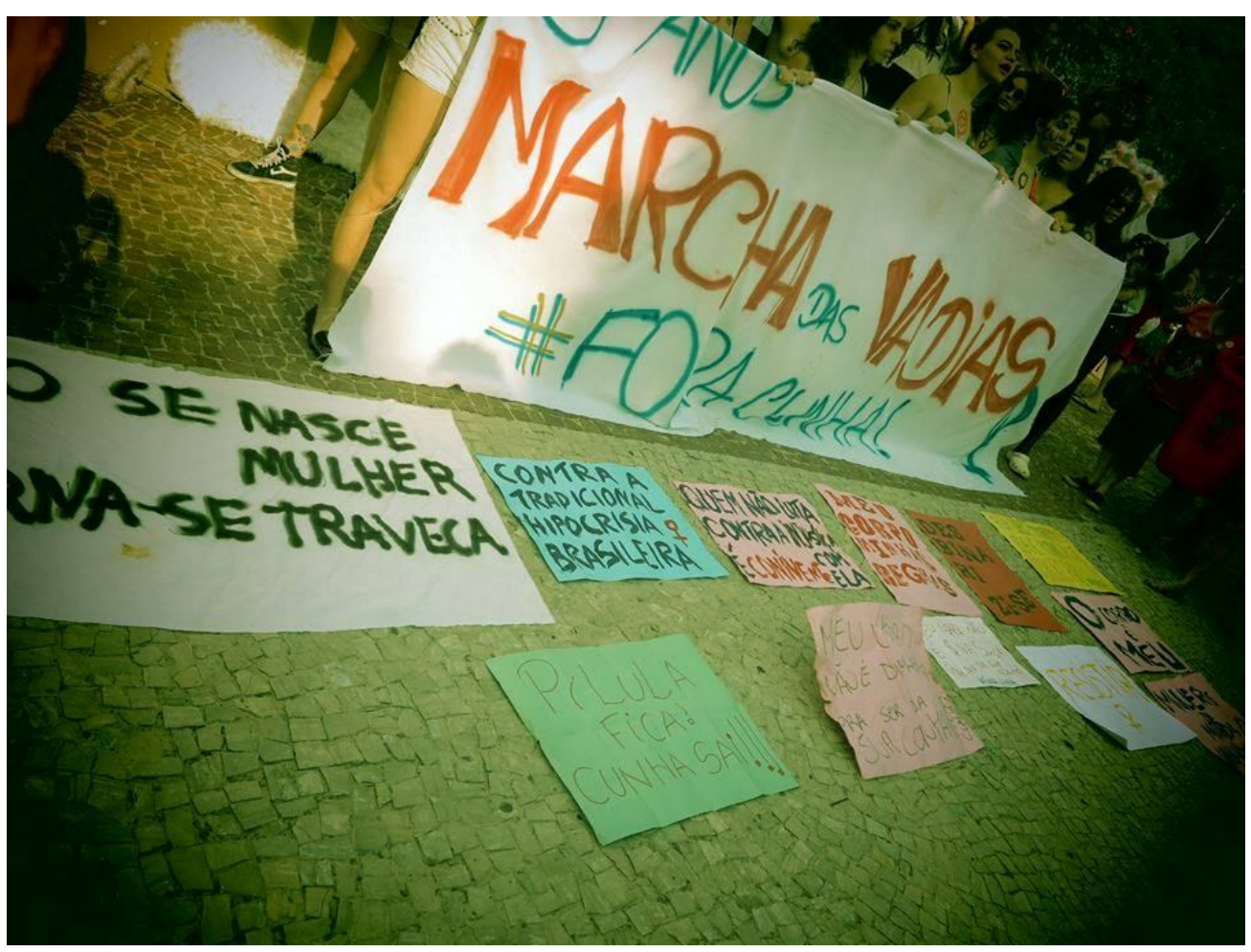

Figura 8: Cartazes do contexto político.

Fonte: Página do Facebook Marcha das Vadias Rio de Janeiro)

A última edição da marcha das Vadias do Rio de Janeiro (2015) teve, como um dos temas, a manifestação da indignação das mulheres participantes do evento em relação às recentes discussões do contexto político nacional. Dentro da Câmara dos Deputados diversos projetos de lei que buscam estabelecer maior controle sobre o corpo das mulheres, estão em debate, tais como um projeto de lei que é contrário a aprovação da legalização do aborto, por exemplo.

Ai! Ai, ai ai

Ai, ai, ai, ai, ai, ai

Se empurrar o Cunha cai!

Ai! Ai, ai ai

Ai, ai, ai, ai, ai, ai

A pílula fica, o Cunha sai!

O contexto político inspirou diversas palavras de ordem no dia 14 de novembro, dia da manifestação. Assim, debates internos e o próprio ato em si mostraram-se espaços nos quais mulheres puderam se unir e fortalecer a luta contra esses retrocessos. Dentre as discussões atuais sobre ser mulher em nossa sociedade, a temática da formação de uma identidade que reivindique a liberdade sobre si é central na Marcha das Vadias do Rio de Janeiro. 
Os debates que fogem ao binarismo de gênero e exercícios da sexualidade demarcam as atuações do movimento. A realização da roda de conversa sobre "Corpos que fogem à norma" foi um exemplo desta atuação. Diversas pessoas falaram no evento. Uma delas se identificou como "gênero fluido" e a maioria das outras pessoas participantes reivindicavam para si e explicitavam isso em voz alta no momento de suas falas o quanto sofreram com a binarização da sociedade, encontrando apoio de todas as pessoas que estavam no evento. Um dos relatos abordava o sofrimento de uma pessoa que se define como gênero fluido e que toda a sua vida conviveu com a "tentativa de matar o feminino" que estava em seu interior.

Nesta perspectiva, Alvarez (2014, p. 44) defende que, na Marcha das Vadias RJ, os discursos fundamentalmente implodem não só a categoria "mulher", mas a própria noção do feminismo, de quem seriam os seus sujeitos privilegiados e sua visão de mundo compartilhada - elementos centrais na constituição de campos discursivos de ação, incluindo tanto o universo trans quanto os movimentos de mulheres negras.

Assim, os debates e análises em torno da importância do movimento, da interseccionalidade e da formação de uma identidade vadia se tornam possíveis e ocasionam em pedagogias de emancipação (ARROYO, 2014) quando encontram espaços nos quais as desconstruções de normas sociais possam ser efetivadas, mesmo que em espaços de curto alcance. As relações interpessoais que demandam a presença física podem ser as bases destes espaços. No entanto, sendo a Marcha das Vadias RJ um tipo de movimento social que se organiza em redes, tal presença não se torna fundamental em todo o processo de construção. A observação do campo apontou que os espaços virtuais potencializam a militância feminista do movimento que estabelece pontes de contato com outras pessoas e outros movimentos. O aprendizado no movimento se dá em diferentes espaços, conforme veremos no subtítulo seguinte.

\section{2}

\section{Uma pedagogia feminista}

Nesta pesquisa, partimos do campo de estudo da educação não formal que, segundo Gohn (2011b, pp. 17-18): 
aborda os processos educativos que ocorrem fora das escolas, em processos organizativos da sociedade civil, ao redor de ações coletivas do chamado terceiro setor da sociedade, abrangendo os movimentos sociais, organizações nãogovernamentais e outras entidades sem fins lucrativos que atuam na área social (GOHN, 2011b, pp. 17-18)

Libâneo (2007, p. 89) define o campo da educação não formal como aquelas atividades com caráter de intencionalidade, porém com baixo grau de estruturação e sistematização, implicando certamente em relações pedagógicas, mas não formalizadas, como as que ocorrem na escola, por exemplo. O campo da educação não formal era visto, de forma genérica, como um conjunto de processos que visavam alcançar a participação individual e de grupos em áreas consideradas rurais, comunitárias, de planejamento familiar e espaços afins (GOHN, 2011b, p. 100). A década de 1990 trouxe um grande destaque aos processos educativos não formais decorrente das mudanças na economia, no mundo do trabalho e na sociedade. A valorização dos processos de aprendizagem e dos valores culturais destacaram as habilidades apreendidas fora dos muros da escola.

A hipótese de Moreira (2014), por exemplo, aplica-se ao cotidiano pedagógico da Marcha das Vadias RJ 2015 quando afirma que a pedagogia que ocorre em movimentos sociais contribui, decisivamente, tanto para a constituição de uma cultura política democrática, por meio da potencialização do diálogo como instrumento básico na constituição de "consensos possíveis" entre os participantes do processo militante.

É contundente apresentar que os movimentos sociais se reconhecem sujeitos de conhecimentos, de valores, de culturas, principalmente, sujeitos de processos de humanização e de emancipação (ARROYO, 2014, p. 25). É a ação coletiva que faz com que as entrevistadas se reconheçam e se mostrem como participantes do movimento e se empoderem para atuar também fora dele.

Acho que a marcha tem muitas potências e cada pessoa ela lida com aquilo de uma forma. Na verdade, ela é muito pessoal, as impressões, as experiências que as pessoas levam pra aquele evento vão trazer ganhos pra ela de diversas formas. (Heloisa)

Isso é um laboratório porque você não tá pegando um livro, lendo em um blog, você ta vendo essas coisas acontecerem lá. [...] Na prática, acho que isso fica mais evidente, vamos dizer. (Beatriz)

A análise dos dados evidencia que a maior importância que o movimento tem para as entrevistadas como fonte de aprendizagens, é perceber que a 
participação na Marcha das Vadias RJ 2015 não impõe uma pedagogia diretiva $\left(\right.$ MIZUKAMI, 1986) ${ }^{40}$ a suas militantes. A militância, em contraposição a uma formação pedagógica baseada na hierarquia, possibilita uma construção coletiva, constante e que se baseia na busca pela horizontalidade e pela troca de saberes. A pedagogia emancipatória oriunda da rotina militante não propõe que uma pessoa eduque a outra, mas sim possibilita espaço em que elas se eduquem. (ARROYO, 2014, p. 27)

Os movimentos sociais contemporâneos como que retomam uma longa e persistente história de resistência às pedagogias dominantes e de afirmação de pedagogias de libertação. Retomam e atualizam uma história de práticas pedagógicas oficiais e de práticas contra pedagógicas não reconhecidas, mas persistentes. (ARROYO, 2014, p. 31)

Tratando-se de um movimento que reivindica novas percepções sobre gênero, sexualidade, liberdade individual e poder de decisão, a criatividade é um dos pontos principais, sendo esta uma característica importante dos espaços de educação não formal. "A questão central dos movimentos sociais é o ser humano como problema" (ARROYO, 2003 In COSTA, 2003, p. 140). Em uma perspectiva freireana, a reprodução da ideologia dominante e/ou o seu questionamento não podem ser vistas como únicas formas de radicalizar a estrutura social e perceber a educação. Esta é, principalmente, uma forma de intervir no mundo. Nesse sentido, as entrevistas e as observações participantes evidenciam que as apropriações realizadas na militância também se transformam em práticas externas e formações de novos discursos.

Com a Marcha eu não aprendi o feminismo, já aprendi o feminismo há 40 anos. Agora, a Marcha me trouxe uma oxigenação, alguma coisa que eu não discutia mais, como foi no ano do papa, que eu tive que discutir com todas as minhas amigas com mais de 45 anos a 60, que é o que digo, elas vieram tirar o mofo do portão dos feminismos dela. E, então, vamos discutir sério isso aqui. As jovens que te trazem um gás, que, às vezes, você tá tão desanimada e você fala: "Oba! De novo tem gente que acredita, que não tá aqui por vaidade". Isso a gente aprende, que é diferente de uma jovem que tá chegando: "Não aprendi tudo, nem sabia o que era feminismo". Então, é no sentido de que a gente aprende sempre a vida inteira, mas não no sentido que aprendi na marcha a ser feminista ou as lutas da pauta

40 Mizukami (1986) aborda que no ensino tradicional a relação interpessoal para a construção do conhecimento está subordinada a uma hierarquia onde um sabe e o outro aprende. $\mathrm{O}$ conteúdo estaria pronto e o método seria a forma que estabelece como uma pessoa aprende. Neste tipo de pedagogia, a pessoa que detém a "autoridade" de ser "dona do conhecimento" possui o poder decisório, de dirigir o processo de ensino e aprendizagem No entanto, há formas não diretivas de se construir o processo de ensino e aprendizagem, tal como defenderei para os movimentos sociais. 
feminista, mas aprendi. A gente aprende a conviver, a conhecer o outro, aprende o limite, a limitação nossa com a outra, isso é o aprendizado do dia a dia, até mesmo quando você tá no ônibus, em casa, em qualquer lugar. (Virginia)

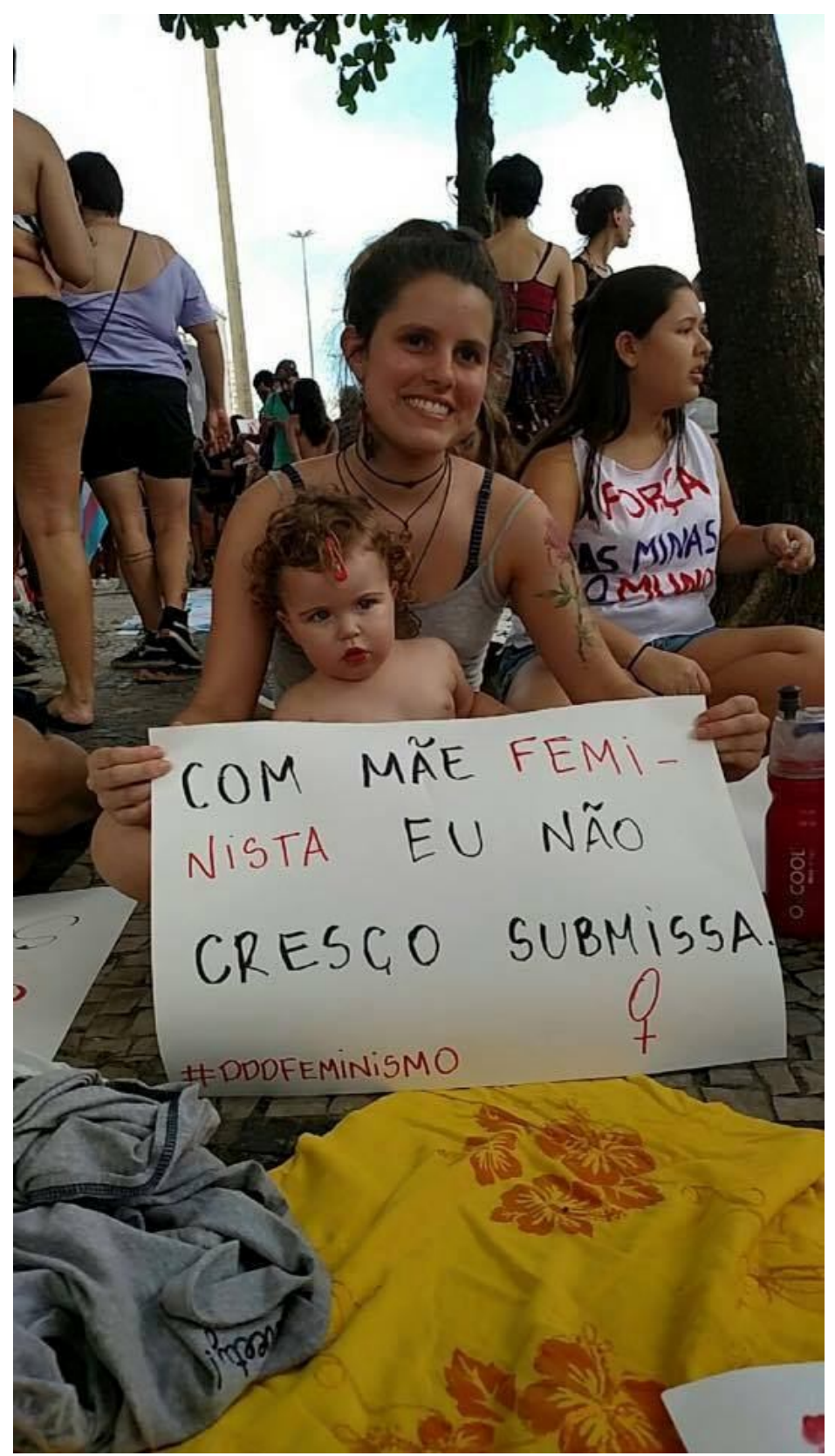

Figura 9: A continuidade da luta.

Fonte: Página do Facebook Marcha das Vadias Rio de Janeiro)

A fala de Virginia e o cartaz que a criança e sua mãe seguram (Figura 9) possibilitam a percepção de que o feminismo tem avançado geração após geração e que os movimentos ainda apresentam constantes modificações, não somente no que diz respeito à adoção de novas bandeiras de luta, mas também quanto à sua forma organizativa. O empoderamento, oriundo da militância da Marcha das 
Vadias do Rio de Janeiro não se materializa somente entre as pessoas que constroem o movimento, mas também com o ato da caminhada e com a repercussão que tal ato possui nas pequenas e grandes mídias. A constante renovação do feminismo e das formas organizativas de luta passa pela caracterização da Marcha das Vadias do Rio de Janeiro como um movimento que se organiza em redes.

\section{3 \\ Uma rede de vadiagem}

A Marcha das Vadias RJ é um tipo de movimento social que se organiza em redes, assim como outros tipos de movimentos que surgiram nos últimos anos tais como as Jornadas de Junho, a Revolução Egípcia ${ }^{41}$ e Ocuppy Wall Street ${ }^{42}$, por exemplos. Para que as mudanças sociais defendidas por estes coletivos se fundamentem e se materializem, Castells (2013) defende que as ações militantes são emocionalmente motivadas, assim como qualquer outro comportamento humano.

Não consigo datar o momento que me percebi feminista, mas posso dizer que meu feminismo passou por questionar esses tipos de obrigações, tendo uma maior auto percepção no fim do ensino médio. Comecei a me aproximar num feminismo de exclusão de homens, odiando todos eles. (...) A ideia principal do feminismo, o direito ao próprio corpo. Se formos pegar toda a história do feminismo, em última análise, o fato de nascer mulher ou se decidir mulher, a luta é pela sobrevivência. Pro nosso corpo não ser violado. É um pedido por existir, não ser estuprada, não apanhar, simplesmente sair e voltar pra casa inteira. (Cláudia)

O entusiasmo, uma poderosa emoção despertada neste tipo de militância, reforça a mobilização societária intencional. A conectividade em rede, o entusiasmo e a superação do medo (resultado da atuação em grupo e não de forma individual somente) formam um ator coletivo consciente. "A tecnologia e a morfologia dessas redes de comunicação dão forma ao processo de mobilização e,

41 Foi uma série de manifestações de rua, protestos e atos de desobediência civil que ocorreram no Egito em 2011. Os principais motivos que deflagraram as foram a violência policial, leis de estado de exceção, o desemprego, o desejo de aumentar o salário mínimo, falta de moradia, inflação, corrupção, falta de liberdade de expressão, más condições de vida e fatores demográficos estruturais. $\mathrm{O}$ principal objetivo dos protestos era derrubar o regime do presidente Hosni Mubarak, que esteve no poder durante trinta anos.

42 É um movimento de protesto contra a desigualdade econômica e social, a ganância, a corrupção e a indevida influência das empresas - sobretudo do setor financeiro - no governo dos Estados Unidos. Iniciado 2011, o movimento consistiu em ocupar ruas nas quais sedes de companhias financeiras se localizam. Posteriormente surgiram outros movimentos Occupy por todo o mundo. 
assim, de mudança social, ao mesmo tempo como processo e como resultado" (CATELLS, 2013, p. 162).

Os movimentos sociais que se organizam em rede possuem algumas características comuns que, no caso da Marcha das Vadias RJ viabilizam a formação de processos pedagógicos que reforçam e criam novas identidades políticas, culturais, coletivas e individuais. Castells (2013) enumera seis características desses novos movimentos sociais.

Em primeiro lugar, Castells (2013) afirma que são movimentos conectados em múltiplas redes. Tais redes não se resumem às redes sociais, mas são também redes online e off-line que interligam as militantes do movimento, formando uma trama multimodal. O espaço urbano não se configura como um limite de sua atuação, visto que as redes sociais são utilizadas como extensores dessa intensa comunicação. Na Marcha das Vadias RJ 2015, isso ocorreu tanto das militantes entre si quanto com outros movimentos e feministas independentes. Esta configuração favorece a não obrigatoriedade da existência de uma liderança. Assim, a "defesa da horizontalidade" configura-se como uma militância constante. A construção de espaços horizontais passa pela deliberação de "espaços autônomos".

Bom, eu gosto dessa coisa da Marcha não ser institucionalizada, a do Rio especialmente. Até pode dialogar com partido, mas não se deixa emparelhar. Eu gosto muito disso, eu tenho essa veia libertária. (...) Já falei um pouco disso, que gosto muito da Marcha do Rio, que é esse ideal de se organizar pela horizontalidade, meio autogestão, já falei também dessa coisa da super autonomia institucional, apesar das mulheres virem de todos os lados, isso que eu gosto da Marcha do Rio. [...] Essa perspectiva do ideal, que é sempre um ideal, é bom dizer, da horizontalidade, autogestão, isso que me seduz. (Beatriz)

É, não tem uma estrutura, né? Isso todo mundo é... A gente é autofinanciado, né, a gente se autofinancia, vende cerveja, faz festa. Mas, assim, eu acho que esse espaço mais horizontal, embora não é uma... Não sou ingênua de achar que é totalmente horizontal, que não tem nenhuma restrição a fala, mas eu acho que é mais horizontal do que qualquer outro espaço feminista que eu já fui depois. Eu acho que isso é bom porque as pessoas podem... Isso facilita, né? A participação das pessoas. Eu acho que é isso. (Nathalia)

Em segundo lugar, para Castells (2013), os movimentos são simultaneamente locais e globais. Iniciam-se em contextos específicos, tendo suas próprias redes de atuação, mas também são globais por se conectar ao mundo inteiro, aprenderem com outras experiências e se estimulam, muitas vezes, por estas experiências a se envolver em suas mobilizações. 
Aí quando, em 2011, a gente estava em uma reunião de ocupa, eu não me lembro o nome do movimento, que teve em São Paulo, aí teve uma reunião aqui para a gente fazer aqui também, não sei o que das liberdades, foi o IFCS, e aí a gente viu uma notícia que aconteceu um negócio no Canadá, e as meninas de São Paulo vão fazer a $1^{\text {a }}$ caminhada de vadias lá. (Virginia)

Então, eu acho que a Marcha das Vadias pra minha vida teve um rebatimento super positivo, por meio de... Aquilo que eu tava falando com você naquele dia, né, que foi no meio da Marcha que eu comecei a participar, né, do movimento de mulheres, a ver essas mulheres, a participar em instâncias diferentes, né, conhecer militâncias e até mesmo a fazer parcerias, por exemplo, a Nathalia, a Antônia, a Indianara... (Manuela)

Em terceiro lugar, esses movimentos, de acordo com Castells (2013), embora se iniciem em redes sociais em alguns casos, eles só se tornam um movimento ao ocupar um espaço urbano, seja de forma permanente de praças públicas ou pela persistência em se manifestar nas ruas.

A primeira Marcha? Ah, a Internet está aí. E o bom da Internet, do Facebook e das redes sociais, eu não lembro se era o Facebook que a gente usava em 2011, acho que era Orkut. E eu sempre fui muito curiosa, sempre pesquisei muito, sempre li muito. Então, eu soube da Marcha no Canadá, que foi a primeira Slut Walk e aí depois eu soube que ia ter no Rio e eu fui. No dia da marcha eu soube que ia ter e fui. (Heloisa)

Minhas amigas tinham me chamado pra participar da primeira reunião e foi criando a marcha. E foi simples assim, na verdade, pelas reuniões a gente foi fazendo e vamos pra quinta Marcha das Vadias. (Indianara)

É porque a Marcha é feito em uma lugar que tem muito visibilidade, de muito contato com a mídia e o primeiro contato de uma pessoa, às vezes, é perguntar: "O que ta acontecendo?" "Que monte de mulher é essa?" "Que gritaria é essa?" "Que gritos de ordens são esses?” É... eu acho que muitas pessoas podem aprender olhando a Marcha e muita gente que está dentro da Marcha é... vai pra Marcha com preconceito e desconstrói lá ou desconstrói nas rodas de conversa. Enfim, nos eventos que precedem a Marcha e é isso, por exemplo, o exemplo que acabou de me dar, eu tenho certeza que nesse dia você aprendeu alguma coisa. (Isa)

Em quarto lugar, Castells (2013) afirma que esses movimentos são amplamente espontâneos e, sua origem, geralmente, é desencadeada por uma centelha de indignação. São movimentos virais, tendo a lógica das redes na Internet como base para esta analogia. A origem do movimento Marcha das Vadias em Toronto desencadeou a organização de mulheres por diversos lugares do mundo. A fala do policial culpabilizando as vítimas de assédio sexual e estupro foi o que gerou esse efeito em dominó.

Então, assim, a origem da marcha das vadias no Canadá foi isso. E um policial foi dar uma palestra de como evitar que elas fosse estupradas porque é a forma como a sociedade lida com isso, a mulher que tem que dar o jeito mágico de não ser 
estuprada. E o cara caiu no absurdo máximo de falar: "Se vocês não querem ser estupradas não se vistam como vadias”. Surgiu aí (Antônia)

Em quinto lugar, segundo Castells (2013), são movimentos profundamente autorreflexivos, ou seja, as militantes se questionam todo o tempo enquanto indivíduos e suas ações.

A Marcha tem influenciado na desconstrução e modificação do meu eu, mas também pode resultar em briga de egos, que surgem num movimento coletivo, diverso, mas ainda institucionalizado. (Cláudia)

Você fica se policiando também. Sabe, vou tomar cuidado pra respeitar mesmo mais as pessoas, né, tentar não atropelar ninguém, não interromper, não silenciar ninguém, né. Tipo, a mulher mais jovem, a mulher mais velha, mulher negra, mulher pobre, você não... Você fica se policiando, assim, pra isso, pra você prestar atenção naquele indivíduo que tá ali com a história de vida dessa pessoa. E, então, acho que isso é um aprendizado muito legal, de respeito mesmo, no sentido mais forte da palavra. (Nathalia)

Por fim, a Marcha das Vadias RJ 2015 não é um movimento violento (CASTELLS, 2013), faz parte do grupo dos novos movimentos sociais (GONH, 2012; ANDRADE, 2015) que raramente são pragmáticos e são bastante políticos em um sentido fundamental, ou seja, desejam transformar o Estado, mas não se apoderar dele. Expressam sentimentos, estimulam debates, mas não criam partidos.

A Marcha das Vadias é um ato pacífico e apartidário que tem como propósito lutar pelo fim de toda violência sexual e de gênero, além de ter defendido, esse ano, outras pautas feministas como os direitos reprodutivos, a descriminalização do aborto, a regulamentação da prostituição e a garantia de Estado laico. (Nota de Posicionamento da Marcha das Vadias RJ 2013 ${ }^{43}$ )

Essas características e dinâmica de organização e militância do movimento são fundamentais para os processos de socialização (MESQUITA, 2003; 2006; 2008) pessoal e política que ocorrem no movimento que geram essas novas pedagogias (ARROYO, 2003; 2014). Essas redes também são geradoras de espaços internos dentro do movimento em que as entrevistadas apontam como fecundos para uma formação pedagógica mais direta.

\section{4}

Espaços pedagógicos: opções do campo

43 Disponível em: http://marchadasvadiasrio.blogspot.com.br/ acesso em 18/03/2016. 
Todas as entrevistadas defenderam que a Marcha das Vadias RJ 2015 é também um movimento pedagógico devido não somente ao fato de que elas aprenderam com a militância, mas também por perceberem que outras mulheres e pessoas simpatizantes a ele também evidenciam seus aprendizados após esta experiência coletiva. A partir das observações, entrevistas e em conversas com as entrevistadas que construíram a Marcha das Vadias RJ 2015, pude perceber que elas também concebem o movimento como um espaço de ensino intencional, no entanto, esta pedagogia passa pelo olhar do feminismo característico do movimento fazendo com que as mulheres que passem pelo movimento (seja na construção ou somente no dia da marcha) passem a ter alguma perspectiva feminista do mundo.

As estratégias pedagógicas, no entanto, variam, pois sem desmerecer e salientar a importância do diálogo, elas acreditam que há alguns momentos em que a formação pedagógica virá por meio de atuações mais diretas e rígidas, que elas denominam de "escrachos". Tais atuações podem se traduzir em um combate mais ofensivo de ideias que reproduzem as normas sociais ou desrespeitam alguma delas que podem se traduzir em discussões, ignorar as pessoas, utilizar do aumento da potência vocal e constranger o outro de maneira que esta pessoa perceba que sua opinião ajuda a legitimar a subalternização das minorias. Estas atuações constituem o que elas chamam de "porrada pedagógica", como disse Antônia em sua entrevista. A violência física e simbólica são alguns dos pontos que mais despertam essas porradas pedagógicas, principalmente em casos que abordam o estupro constituindo inspirações para a produção de cartazes que diziam "Respeita as mina, porra!" e "Não é um elogio se me sinto violada!" e palavras de ordem como as seguintes:

Pau de estuprador no liquidificador!

Pau de estuprador no liquidificador!

O Pedro Paulo ${ }^{44}$ não passará!

Espancador não pode governar!

No bloco de perguntas do roteiro de entrevista (Apêndice 6.5) que buscou a relação entre a Marcha das Vadias RJ com o campo da educação foi feito a cada

44 Pedro Paulo foi pré-candidato à prefeitura do Rio de Janeiro. Recentemente, veio a público uma denúncia de sua esposa de que ele teria agredido-a fisicamente. 
uma das entrevistadas o seguinte questionamento: "O que você mais aprende nas reuniões, nas atividades públicas e nos fóruns virtuais? Quais desses espaços da Marcha das Vadias você considera que sejam mais educativos para as mulheres? Por quê?”. Das respostas obtidas, a imagem a seguir (Figura 10) foi produzida:

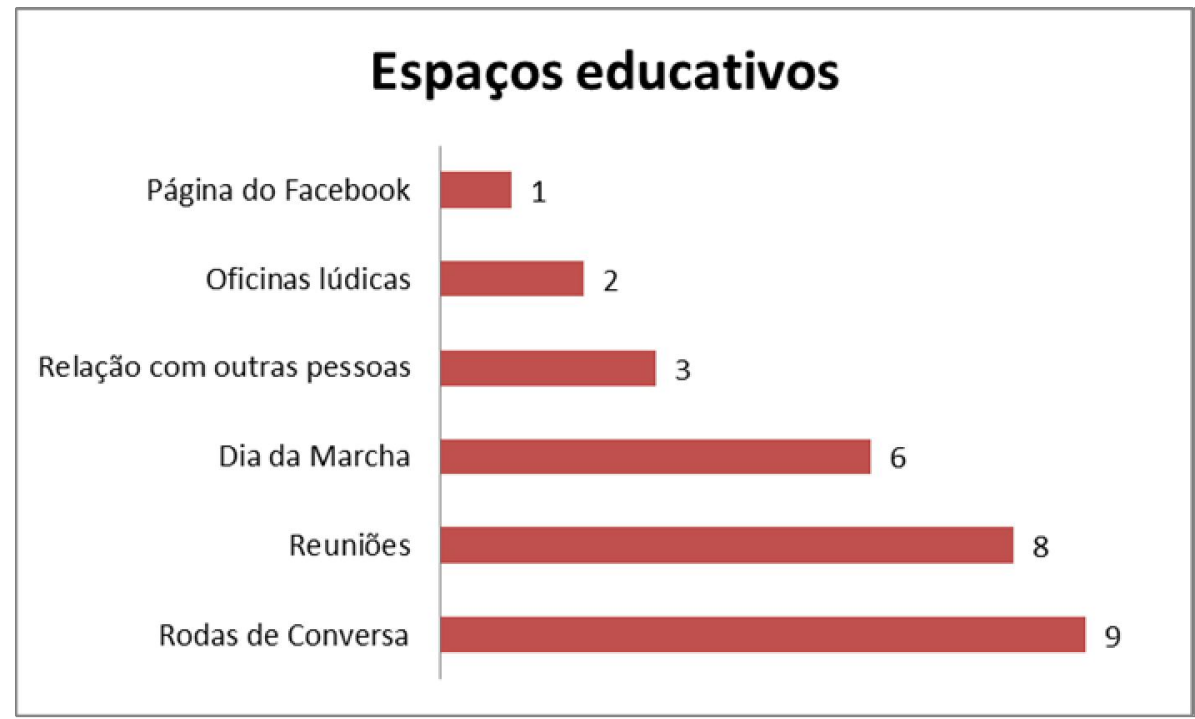

Figura 10: Gráfico de espaços educativos.

Fonte: BARROCA, 2016.)

O destaque das rodas de conversa como um campo frutífero para aprendizado e sua aproximação com o campo de educação formal não é algo que pode ser ignorado na análise.

Rodas de conversa. Eu acho que rola um aprendizado muito legal e... na Marcha em si. No dia da marcha, eu acho que um dos maiores aprendizados, claro que não se pode ignorar e seria bem capacitista ignorar os espaços virtuais, que nem sempre é viável... Mas, nem sempre é viável pra muitas mulheres irem pras reuniões presenciais, nos encontros e na própria marcha. Mas, eu acho que na minha visão, assim nas poucas rodas de conversa que eu posso ir e na marcha é onde rola o aprendizado e a troca mais intensa. (Isa)

No entanto, a metodologia empregada nestes eventos se diferencia de aulas ou palestras. Em movimentos sociais, em especial na Marcha das Vadias do Rio de Janeiro, são valorizados aspectos como a criatividade, a horizontalidade, as vivências. Na Marcha das Vadias RJ 2015, estas experiências são destaque em toda a construção, não somente nos eventos.

A construção inteira porque o papo de reunião continua na mesa de bar, que vai continuar na roda de... na troca de e-mail. Eu acho que fazer a experiência da marcha das vadias não é só o dia da marcha, é tudo. É desde uma ligação pra uma companheira da marcha do tipo: "E aí, onde e que vai ser?" até as reuniões, rodas, tudo, tudo. Não tem como dissociar um momento do outro na marcha. (Heloisa) 
A roda de conversa sobre consentimento, por exemplo, se estruturou a partir dos relatos das participantes. A discussão foi baseada nessas experiências relatadas e o aprendizado sobre estes assuntos foi a partir desta metodologia específica. A sensibilização das pessoas presentes a outros temas que nem sempre fazem parte de sua rotina de todas as pessoas presentes.

As formações pedagógicas individuais e coletivas foram apreendidas de diferentes formas pelas entrevistadas, conforme observamos ao longo dessas três temáticas de análise. É importante destacar que o movimento não pode e nem deve ser reduzido a estes três temas-chave de análise. A "leveza" apontada por muitas entrevistadas sobre a construção do movimento faz com que elas continuem nele em edições subsequentes e que outras pessoas também se aproximem, apesar da rotatividade e de poucas mulheres envolvidas na edição de 2015 .

As reuniões para a construção da Marcha das Vadias RJ 2016 já se iniciaram no dia 18 de fevereiro do presente ano e o número de participantes gira em torno de 15 pessoas até o momento. Mulheres de diferentes idades e com diferentes experiências fazem parte da construção ou somente do dia da marcha todos os anos dando novas roupagens e características ao movimento.

As pedagogias emancipatórias (ARROYO, 2014) presentes no movimento se traduzem em diferentes espaços da construção. As observações do campo apontam que a rotina militante não se resume somente aos encontros de organização para a marcha ou na caminhada em si, mas que estes espaços são utilizados para potencializar e sustentar o despertar de cada participante para uma visão feminista sobre o mundo que nos cerca. O conhecimento sobre si, a formação de redes online e off-line, as discussões sobre gêneros, sexualidade, corpos, maternidade, capacitismo, transgeneridade, demandas de prostituição que ocorrem em todos os espaços da Marcha das Vadias RJ 2015 são mais que meramente informativos. A perspectiva de empoderar a si mesma passa pela construção coletiva, na medida em que essa atuação em conjunto possibilita a percepção de que as opressões não são individuais e que um confronto coletivo se apresenta como ferramenta fundamental para transgredir a ordem social, mesmo que esta transgressão se dê em espaços mais próximos a cada militante. 
A Marcha das Vadias do Rio de Janeiro considera que é necessário o empoderamento das mulheres e das pessoas trans e que a adoção do feminismo interseccional é o caminho para que a sociedade e o feminismo avancem no combate à cultura de subalternização da mulher e dos corpos que fogem a uma normal social imposta.

A formação identitária hoje do movimento pressupõe que as diferentes mulheres que o constroem sintam-se "vadias" como meio de subverter e de se empoderar na luta contra o imaginário social contemporâneo em que a definição do termo "vadia" é estar à margem de tudo que é considerado "direito, moralmente aceito e positivo" nas definições do que é ser mulher. A Marcha das Vadias RJ é um movimento social no qual a diferença é convidada constantemente para fazer parte da construção e rotina militante. Esse é um dos grandes pontos de oposição no qual as pedagogias da emancipação (ARROYO, 2014) presentes nos movimentos sociais se diferenciam dos espaços de ensino formais, onde as diferenças são hierarquizadas e silenciadas (ANDRADE; CÂMARA, 2015). 


\section{6 Considerações finais}

No primeiro capítulo, apresentei a minha trajetória de vida na qual a perspectiva pessoal e acadêmica estiveram diretamente ligadas para a formação do presente tema de pesquisa. A partir da experiência militante no ensino superior, em instituições políticas e das formações obtidas, pude sentir as opressões da violência sexual e de gênero as quais estou subjulgada. Tais vivências confluíram para que a pesquisa desenvolvida no mestrado pudesse auxiliar na compreensão desses processos e que também pudesse apresentar formas de resistência desempenhadas por outras mulheres. Assim, este primeiro capítulo foi dedicado a apresentação desta trajetória, do tema, das questões de investigação, objetivos e metodologia de pesquisa empregadas para que a intenção de compartilhar os aprendizados obtidos no campo pudesse vir a tona. O texto e o contexto foram produzidos dentro de uma fronteira (MARTINS, 1997) bastante peculiar, visto que dialoga com movimentos sociais, movimentos feministas e o campo da educação não formal.

O segundo capítulo parte da definição de movimentos sociais (GOHN, 2011a) e das novas formas de organização destes movimentos (GOHN 2011a, 2011b, 2012, 2014; MESQUITA, 2003, 2006, 2008; CASTELLS, 2013, 2015; RUSSO, 2011). Assim, o capítulo apresenta uma contextualização histórica do movimento feminista no mundo e no Brasil e uma explicitação das suas três gerações. A partir das mudanças estruturais da sociedade e dos modelos organizacionais da militância feminista, a Marcha das Vadias surge como movimento que articula diferentes dimensões de todas as gerações das lutas das mulheres. Neste capítulo, foi apresentado o contexto de surgimento do movimento Marcha das Vadias no Canadá, sua repercussão do mundo e o histórico de sua criação no Rio de Janeiro em 2011. O campo, a entrada no campo e as entrevistadas também foram apresentados neste capítulo.

A partir da imersão no campo, na perspectiva de uma pesquisa participante (DEMO, 2008), pude vivenciar maneiras pelas quais ocorrem algumas dessas 
formações pedagógicas emancipatórias (ARROYO, 2014) oriundas desse processo. Da análise dos dados obtidos nas observações, nas entrevistas e nas produções on line da Marcha das Vadias do Rio de Janeiro obtive três temaschave que compõem os capítulos 3, 4 e 5, sendo estes os componentes de análise desta pesquisa.

O terceiro capítulo, primeiro tema-chave de análise, apresentou os conceitos de gênero e sexualidade e de que forma são tratados pela Marcha das Vadias RJ 2015 em seus discursos e práticas militantes. Neste capítulo, também foram abordadas algumas teorizações acerca da construção do corpo enquanto vitrine identitária dos gêneros e das sexualidades e sua utilização como ferramenta de mobilização política por meio da ocupação de espaços públicos e da utilização do mesmo como evidência de protestos. A partir das análises deste tema chave foi possível concluir que a defesa da autonomia em diferentes aspectos, tendo o aspecto físico e psicológico como norteadores, é oriunda da necessidade do sentimento de liberdade e libertação das padronizações que as normais sociais impõem. O empoderamneto - oriundo da da ressignificação de conceitos (gênero e sexualidade, por exemplo), da reconstrução de identidades e valores morais individuais e da vivência da experiência coletiva - possibilita para as integrantes da Marcha das Vadias RJ 2015 novas formas de reflextir, agir e sentir emsociedade. A busca incessante por reconhecimento e a luta pela superação das condições históricas de subalternização e invisibilização encontram materialidade em pedagogias emancipatórias (ARROYO, 2003, 2014).

O quarto capítulo apresentou o segundo tema-chave de análise que trata das relações entre o tema da diferença e a defesa da interseccionalidade (CRENSHAW, 2002) da Marcha das Vadias RJ. A partir do convite constante de que as diferenças façam parte da coletividade feminista do movimento carioca, desafios e dificuldades se apresentam para a coexistência delas e para a construção de uma militância que busca lutar contra diferentes tipos de opressões sociais. As dificuldades de se estabelecer um diálogo com as mulheres feministas negras (HOOKS, 2013) se apresenta como um dos conflitos mais marcantes do movimento, tendo como causa e consequência a presença de somente uma mulher negra na construção da marcha das Vadias RJ 2015, por exemplo. A busca por reconstrução das militantes de forma que percebam os limites dessa ponte foram abordados neste capítulo. Assim, foi possível concluir que os caminhos para este 
diálogo ainda estão em andamento e que a defesa da horizontalidade real no interior desta militância ainda se transformam.

Por, fim, o capítulo 5 apresenta o terceiro e último tema-chave que aborda o movimento Marcha das Vadias RJ e sua edição de 2015 como um espaço de formação pedagógica não formal (GOHN, 2012; LIBÂNEO, 2007). Foi possível concluir que a formação de uma identidade vadia, isto é, de uma identidade coletiva e individual de um movimento tão multicultural (ANDRADE, ano) necessita do conflito constante entre as diferenças que se aproximam do movimento de forma a possibilitar que suas integrantes se situem historicamente e alcancem possibilidades reais de luta igualitária e coletiva sem a reprodução de hierarquias sociais em seu interior. A partir da compreensão de quais espaços compõem o campo da formação não formal, foi possível concluir que no movimento feminista em questão, por meio de diferentes espaços, incluindo os que foram apresentados pelas entrevistadas, as formações pedagógicas com vistas à emancipação são possíveis. A atuação coletiva torna-se fundamental para a construção de redes que se apresentam como espaços que complementam as relações interpessoais presenciais. A caracterização da Marcha das Vadias RJ como um movimento que se organiza em redes (CASTELLS, 2013) auxilia no entendimento das estruturas organizacionais do movimento e também da compreensão de que o empoderamneto coletivo se apresenta como essencial para que as participantes do movimento vislumbrem táticas de transgredir algumas das normas sociais vigentes de forma a possibilitar que sua liberdade e autonomia enquanto mulher, ser político e feminista se materialize.

Retomando, mais uma vez, as questões de pesquisa, pude perceber que o aprender a ser "vadia" engloba várias dimensões que relacionam a identidade, as formações culturais as quais estamos imersas e os embates entre o que éramos e o que passamos a ser enquanto vivemos o movimento. As questões relativas ao gênero englobam o movimento e não somente estas questões, mas também as de sexualidade, raça, etnia, classe social, lugar de moradia, prostituição e afins.

As pedagogias da emancipação (ARROYO, 2013; 2014) presentes no movimento são percebidas como oriundas das práticas e das resoluções de conflitos. Assim, ao longo da pesquisa, percebi que o movimento opta por rodas de conversa, utilização das redes sociais, oficinas interativas, reuniões coletivas e com o próprio dia da marcha (culminância) como espaços que propiciam uma 
pedagogia feminista. Na vivência do movimento, essas pedagogias emancipatórias feministas se articulam como educação não formal, por centralizar as formações humana, política e social, bem como a atuação pessoal e coletiva como eixos principais.

As falas das entrevistadas e as observações participantes evidenciaram, ao longo da análise realizada, formas pelas quais as diferenças são tratadas dentro do movimento e as possibilidades de avanços originadas da centralização do diálogo. Este diálogo torna-se essencial para que cada participante perceba as diferentes vivências possíveis a partir de outras óticas que não apenas a sua própria. Desta forma, além do exercício de empatia, as militantes do movimento e suas redes de contato se criam de forma a fortalecer a luta coletiva e individual.

Tratando-se de uma pesquisa participante (DEMO, 2008), é importante demarcar que a coleta dos dados centrais da pesquisa (observações e entrevistas) esteve condicionada à minha presença na construção do movimento. Assim, todo o lugar que ocupei era definido pelo campo, numa prática de pesquisa posicionada e dirigida, sem, no entanto, abrir mão do rigor analítico que caracteriza as pesquisas qualitativas em educação.

As militantes foram gradativamente cedendo espaço e juntas construímos laços oriundos da socialização política (MESQUITA, 2003; 2006; 2008) e de amizade. Por ter feito parte do processo e me dedicado inteiramente a ele, registro que aprendi muito. Procurando compreender as pedagogias emancipatórias e feministas do movimento, compreendi de dentro como este processo ocorre. Das falas das entrevistadas e das vivências com cada uma delas, percebi, pela ótica de pesquisadora e de militante feminista, o sentido e a importância do empoderamento, da interseccionalidade e da valorização do diálogo e das diferenças.

O constante convite da Marcha das Vadias RJ para que as diferenças estejam presentes faz com que este seja um espaço pedagógico intenso e positivo para uma formação multicultural (ANDRADE, 2009) nas quais diferentes identidades coexistem com poucas hierarquizações, mesmo que os conflitos ainda façam parte dele. A não resolução das questões relativas entre o diálogo entre o feminismo branco e o feminismo negro não exclui as constantes tentativas e os avanços que foram realizados até o momento. 
A pesquisa apresentou também que o movimento feminista ainda tem um longo caminho para percorrer na garantia de direitos iguais e da valorização de identidades. No entanto, a constante aposta no diálogo evidencia uma possibilidade metodológica para atingir este objetivo e para fomentar o exercício e a defesa de uma formação intercultural, como forma de combater à hierarquização e exclusão das diferenças.

Devida à mudança constante do próprio campo, haja vista que a cada edição da Marcha das Vadias RJ as participantes e os conflitos de suas relações se alteram, considero que nenhuma das categorias de análise aqui apresentadas poderiam ser generalizadas. Portanto, todas as análises aqui presentes podem se apresentar incoerentes com o campo em estudos de edições posteriores da marcha das Vadias do Rio de Janeiro. No entanto, podemos fazer cinco afirmativas, com relativa segurança, a saber: (i) a Marcha das Vadias tem grande potencial pedagógico emancipatória para suas militantes e, até mesmo, suas simpatizantes; (ii) a interseccionalidade é, por um lado, um horizonte de sentido e, por outro, um grande desafio para a Marcha das Vadias RJ; (iii) há uma "identidade vadia" sendo construída e reconstruída, dando sentido para muitas lutas feministas em torno de questões de gênero e sexualidade; (iv) o corpo das mulheres, para além das defesas de liberdade e inviolabilidade, tem se tornado palco da luta por direitos; (v) as perspectivas de gêneros e sexualidades embasam a formação de autonomia sobre os corpos e atuações políticas individuais e coletivas.

Assim, as percepções sobre o movimento podem ser ampliadas, mas com restrições. Pelo fato de estar no campo também enquanto pesquisadora, o processo de formação ao qual também fui submetida esteve constantemente sob atenção redobrada para garantir melhor compreensão do processo vivido. $\mathrm{O}$ fato de estar diretamente envolvida com a construção do campo fez com que eu também percebesse as alterações que o mesmo teve em minha própria reconstrução.

Enquanto pesquisadora de um movimento e tão imerso na defesa da diferença, aprendi que o diálogo não é um caminho que deve ser secundarizado nas relações interpessoais. A cada experiência no campo compreendi minha posição de privilégios em relação a outras mulheres. Perceber esse lugar de fala não é algo fácil de desconstruir e sei que ainda tenho um longo caminho para que o debate e a luta conjunta com outras mulheres sejam possíveis. As influências do campo em minhas concepções pessoais acerca dos homens e da relação com eles 
foram crescendo ao longo do tempo. Após um ano no campo, perceber as limitações que impedem os diálogos entre homens e mulheres em busca de uma sociedade igualitária foi essencial para a criação de estratégias de diálogo com as pessoas que ocupam, socialmente, a posição de privilégios, sejam homens, pessoas cis, mulheres brancas, pessoas heterossexuais, etc. A questão, talvez, seja sobre como abrir mão de da situação de privilégio, reconhecer o poder assimétrico e desigual das identidades e, além disso, evitar atitudes de opressão?

A partir da experiência de pesquisadora e de militante, a percepção da importância do diálogo entre identidades diferentes originaram outras questões. No entanto, todas elas referem-se ao contexto da escola, que se mostra em uma direção oposta à que foi percebida na Marcha das Vadias. Por exemplo, enquanto o movimento quer ouvir as pessoas e saber como se definem, como querem ser nomeadas e o que propõem, o ambiente formal ainda se mostra muito reticente a isto. O convite para que o movimento fosse até uma escola debater com os jovens é uma das evidências de que este debate se mostra necessário nas escolas. Assim, porque o ambiente escolar ainda é resistente para tratar das questões sobre gêneros, sexualidades e corpos em seu interior? Quais são as reais possibilidades de diálogo entre o campo formal e os movimentos sociais? A partir do estreitamento das relações entre estes campos, seria possível maior promoção de uma educação escolar voltada para a defesa da não hierarquização das diferenças? Para responder a estas questões mais pesquisas precisam ser desenvolvidas na área. Quem sabe, eu possa enfrentá-las num futuro próximo.

Embora o campo de estudos entre movimentos sociais e educação e as relações de gênero esteja se desenvolvendo, ainda existem muitas lacunas a serem preenchidas. $\mathrm{O}$ fomento a estudos nesta área fronteiriça ainda se faz necessário. 


\section{Referências bibliográficas}

ALMEIDA, Carla Cristina Lima de. Corpo e Gênero: Articulando um debate In Em Pauta, v. 9, n 28, PP. 17-27, dezembro, 2011.

ALVAREZ, Sonia E. Para além da sociedade civil: reflexões sobre o campo feminista In Cadernos Pagu: Campinas, nº43, janeiro-junho, p. 13-56, 2014.

ALVES, Karina Mirian da Cruz Valença. A subjetivação da mãe naturalista como modelo: a maternidade como efeito das pedagogias culturais In $35^{a}$ Reunião Anual ANPEd. Porto de Galinhas, 2012. Anais. Pernambuco: ANPEd, 2012.

ANDRADE, Marcelo. A diferença que desafia a escola: Apontamentos iniciais sobre a prática pedagógica e a perspectiva intercultural In ANDRADE, Marcelo (org.) A diferença que desafia a escola: A prática pedagógica e a perspectiva intercultural. Rio de Janeiro: Quartet, 2009.

Movimentos Sociais, Educação e Diferenças: definições analíticas e equivalentes práticos In Currículo sem Fronteiras, v. 15, n. 3, pp. 816-831, set./dez, 2015.

ANDRADE, Marcelo e CÂMARA, Luiz. Diferenças silenciadas e diálogos possíveis: a pesquisa em educação como superação de silenciamentos In ANDRADE, Marcelo (org.) Diferenças silenciadas: Pesquisas em educação, preconceitos e discriminações. Rio de Janeiro: 7 letras, 2015.

ANDRADE, Sandra dos Santos. Juventudes e processos de escolarização: articulações entre trabalho e gênero In $34^{a}$ Reunião Anual - ANPEd. Natal, 2011. Anais. Rio Grande do Norte: ANPEd, 2011.

ARROYO, Miguel G.. Pedagogias em movimento: o que temos a aprender dos movimentos sociais. Currículo sem fronteiras. V. 3, n.1, 2003.

. Outros Sujeitos, Outras Pedagogias. $2^{\circ}$ edição. Petrópolis: Vozes, 2014.

BARROSO, Carmen. Metas de desenvolvimento do milênio, educação e igualdade de gênero In Cadernos de Pesquisa, v. 34, n. 123, p. 573-582, set. - dez. 2004.

BASTOS, Felipe. "A diretora sabe que você está trabalhando isso na sala de aula?": Diversidade sexual e ensino de ciências. Dissertação (Mestrado) - Pontifícia Universidade Católica do Rio de Janeiro, Departamento de Educação, 2015.

BEUAVOIR, Simone. O Segundo Sexo: Fatos e Mitos. 4 ed. São Paulo: Difusão Européia do livro, 1970.

BOURDIEU, Pierre. A dominação Masculina. Trad. Maria Helena Kühner, Rio de Janeiro: Bertrand Brasil, 1999.

CAMPOS, Miriam Piber. Identidades "anormais": A (des)construção dos corpos

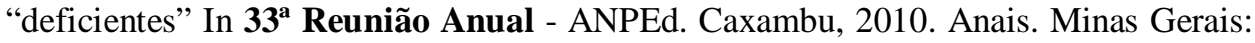
ANPEd, 2010.

CASTELLS, Manuel. Redes de indignação e esperança: Movimentos Sociais na era da internet. Tradução: Carlos Alberto Medeiros, $1^{a}$ edição: Zahar, Rio de Janeiro, 2013. 
"A comunicação em rede está revitalizando a democracia": depoimento. 11 jun, 2015. Bahia: Fronteiras do Pensamento. Entrevista concedida a Malu Fontes, 2015.

CASTRO, Roney Polato de; FERRARI, Anderson. "Nossa! eu nunca tinha parado pra pensar nisso!" - gênero, sexualidades e formação docente In $\mathbf{3 3}^{\mathbf{a}}$ Reunião Anual ANPEd. Caxambu, 2010. Anais. Minas Gerais: ANPEd, 2010.

CHAVES, Tyara Veriato. Marcha das Vadias. Corpo, sujeito e ideologia. Seminário Internacional Fazendo Gênero 10 (Anais Eletrônicos), Florianópolis, 2013.

COSTA, Marisa Vorraber (org.). A escola tem futuro?. Rio de Janeiro: DP\&A, 2003.

CRENSHAW, Kimberlé. Documento para o encontro de especialistas em aspectos da discriminação racial relativos ao gênero. Estudos Feministas, University of California, Los Angeles, pp. 171-188, 2002.

CYRINO, Rafaela. A categorização do masculino e do feminino e a ideia de determinismo cultural: uma crítica epistemológica aos usos normativs do gênero. Seminário Internacional Fazendo Gênero 10 (Anais Eletrônicos), Florianópolis, 2013.

DEMO, Pedro. Pesquisa Participante: saber pensar e intervir juntos: Liber Livro Editora, $2^{a}$ edição, Brasília, 2008.

DUARTE, Rosália. Pesquisa qualitativa - reflexões sobre o trabalho de campo. Cadernos de Pesquisa, n. 115, p. 139-154, março, 2002.

DUTRA, Mariana Passos; NUNES, Tiago García. A Marcha Das Vadias como redes de movimentos e significados In Revista Prolegómenos - Derechos y Valores, pp.153168, 2015.

FINCO, Daniela. Igualdad de género en las instituciones educativas de la primera infancia brasileña In Revista Latinoamericana de Ciencias Sociales, Niñez y Juventud, vol.13 no.1 Manizales Jan - June 2015.

GAGNON, John. Epílogo: Revisitando a conduta sexual (1998) In: Uma interpretação do desejo: ensaios sobre o estudo da sexualidade. Rio de Janeiro: Garamound, 2006.

FREIRE, Paulo. Pedagogia do oprimido. Rio de Janeiro: Paz e Terra, 12a edição, 1983.

Pedagogia da autonomia: Saberes necessários à prática educativa. São Paulo: Paz e Terra, 34ª edição, 1996.

GIL, Antônio Carlos. Como elaborar projetos de pesquisa. $4^{\mathrm{a}}$ ed., São Paulo: Atlas, 2002.

GOHN, Maria da Glória. Movimentos sociais na contemporaneidade. Revista Brasileira de Educação, v. 16, n. 47, maio-ago, 2011 A.

Movimentos Sociais e Educação, 8 ${ }^{\text {a }}$ edição, São Paulo: Cortez, 2011b.

Movimentos Sociais e Educação. 8ª ed., São Paulo: Cortez, 2012.

. Sociologia dos Movimentos Sociais. $2^{\mathrm{a}}$ edição, São Paulo: Cortez, 2014.

GOLDFARB, Raquel Costa; MINELLA, Luzinete Simões; LAGO, Mara Coelho de Souza. Marcha das Vadias na Paraíba: Sororidades, Performances e Linguagem. Seminário Internacional Fazendo Gênero 10 (Anais Eletrônicos), Florianópolis, 2013.

GOMES, Carla; SORJ, Bila. Corpo, geração e identidade: a Marcha das vadias no Brasil. Sociedade e Estado. Brasília, v. 29, n. 2, maio/agosto, 2014. 
GROPPO, Luís Antonio. A gênese do campo das práticas socioeducativas no Brasil: educação popular, educação não formal e pedagogia social In $37^{\mathbf{a}}$ Reunião Anual ANPEd. Florianópolis, 2014. Anais. Santa Catarina: ANPEd, 2014.

GURGEL, Telma; ALMEIDA, Janaiky. Feminismo e as jovens feministas: Desafios programáticos e organizativos. Seminário Internacional Fazendo Gênero 10 (Anais Eletrônicos), Florianópolis, 2013.

HARVEY, David. Os rebeldes na rua: o Partido de Wall Street encontra sua nêmesis. Occupy. São Paulo: Boitempo Carta Maior, 2012.

hooks, bell. Ensinando a transgredir: a educação como prática de liberdade. Trad. Marcelo Brandão Cipolla: Editora Martins Fontes, São Paulo, 2013.

HUZIOKA, Lilam Litsuko. Conscientização contra a opressão de gênero: mulheres populares e os desafios nas margens do sistema mundo moderno/colonial. Seminário Internacional Fazendo Gênero 10 (Anais Eletrônicos), Florianópolis, 2013.

JORDÃO, Albertina. Estudo sobre a aplicação da lei da paridade do projeto promoção da cidadania e da igualdade de gênero In Ex aequo, no 31, junho, 2015.

LE BRETON, David. "O corpo tornou-se um simples acessório" 05 Fev., 2008. Rio Grande do Sul: Instituto Humanitas Unisonos. Entrevista concedida a Flávia Tavares, 2008.

Corpo, Gênero, Identidade In FERRARI, Anderson; RIBEIRO, Cláudia Maria; CASTRO, Roney Polato de; BARBOSA, Vanderlei (ogrs.). Corpo, gênero e sexualidade, Lavras: UFLA, 2014.

LIBÂNEO, José Carlos. Tendência pedagógicas na prática escolar In: Filosofia da educação, São Paulo: Cortez, 1990, p. 53-75.

. Pedagogia e pedagogos, para quê? 9ª edição, São Paulo: Cortez Editora, 2007.

LOURO, Guacira Lopes; NECKEL, Jane Felipe; GOELLNER, Silvana Vilodre. Corpo, Gênero e Sexualidade: Discussões In Revista Estudos Feministas, Florianópolis, Janeiro-Junho, PP. 179-199, 2005.

LUCKESI, Cipriano Carlos. Educação e sociedade: redenção, reprodução e transformação In: Filosofia da educação, São Paulo: Cortez, 1990, p. 37-52.

MARTINS, José de Souza. Fronteira: a degradação do outro nos confins do humano. São Paulo: Hucitec, 1997.

MARQUES, Gabriela Miranda. Feministas libertárias: Práticas contemporâneas de resistência. Seminário Internacional Fazendo Gênero 10 (Anais Eletrônicos), Florianópolis, 2013.

MATTOS, Amana Rocha. Sobre Vadias, professores e Black Blocs: as ruas e a construção do dissenso político no Brasil In Symposium in International Languages, Vol. 40, No. 1, 2014.

MESQUITA, Marcos Ribeiro. Movimento estudantil brasileiro: Práticas militantes na ótica dos Novos Movimentos Sociais Cultura e política: A experiência dos coletivos de cultura no movimento estudantil In Revista Crítica de Ciências Sociais, $n^{\text {o: }}$ 66, outubro, 2003.

Identidade, cultura e política: Os movimentos estudantis na contemporaneidade 377 f., Tese (Doutorado) Pontifícia Universidade Católica de São Paulo, São Paulo, 2006.

Cultura e política: A experiência dos coletivos de cultura no movimento estudantil In Revista Crítica de Ciências Sociais, n $^{\text {: }}$ 81, junho, 2008. 
MIZUKAMI, Maria da Graça Nicoletti. Ensino: as abordagens do processo, São Paulo: EPU, 1896.

MORAIS, Janaina de Araujo. Quem são essas vadias? Uma análise teórico-empírica sobre o "sujeito político" da Marcha das Vadias do Rio de Janeiro. Seminário Internacional Fazendo Gênero 10 (Anais Eletrônicos), Florianópolis, 2013.

MOREIRA, Carlos Eduardo. A educação popular e a construção de políticas públicas em educação: entre o personalismo político e a participação cidadã In $37^{\mathbf{a}}$ Reunião Anual - ANPEd. Florianópolis, 2014. Anais. Santa Catarina: ANPEd, 2014.

MURACA, Maria Teresa. Método e metodologia entre pedagogia popular e feminismo In 37 ${ }^{\text {a }}$ Reunião Anual - ANPEd. Florianópolis, 2014. Anais. Santa Catarina: ANPEd, 2014.

NAME, Leo; ZANETTI, Julia P. Meu corpo, minhas redes: A Marcha das Vadias do Rio de Janeiro. Anais Encontros Nacionais da XVI ANPUR, Recife, 2013.

OLIVEIRA, Ivanilde Apoluceno de; FONSECA, Maria de Jesus da Conceição Ferreira; SANTOS, Tânia Regina Lobato dos. A entrevista na Pesquisa Educacional In MARCONDES, Maria Inês; TEIXEIRA, Elizabeth; OLIVEIRA, Ivanilde Apoluceno de (orgs.). Metodologias e Técnicas de Pesquisa em Educação, Belém: EDUEPA, 2010.

OLIVEIRA, Júlia Glaciela da Silva. Intervenções estético-urbanas: Novas políticas dos feminismos latino americanos. Seminário Internacional Fazendo Gênero 10 (Anais Eletrônicos), Florianópolis, 2013.

OLIVEIRA, Leidiane Souza de. Movimento feminista: sujeito político e coletivo central na luta das mulheres Seminário Internacional Fazendo Gênero 10 (Anais Eletrônicos), Florianópolis, 2013.

OLIVEIRA, Romualdo Portela de. Da universalização do Ensino Fundamental ao desafio da qualidade: uma análise histórica Educação Sociedade, Campinas, vol. 28, n. 100 Especial, p. 661-690, out. 2007.

PRONI, Marcelo Weishaupt; GOMES, Darcilene Claudio. Precariedade ocupacional: uma questão de gênero e raça In Estudos Avançados, vol.29, nº 85 São Paulo Set. Dez., 2015.

RODRIGUES, Carla; HEILBORN, Maria Luiza. Gênero e pós-gênero: um debate político. Seminário Internacional Fazendo Gênero 10 (Anais Eletrônicos), Florianópolis, 2013.

RUBIN, Gayle. Thinking Sex: notes for a radical theory of the politics of sexuality. In: NARDI, P. M.; SCHNEIDER, B. E. (Ed.) Social Perspectives in lesbian and gay studies: a reader. New York: Routledge, 1998.

RUSSO, Kelly. Os "argonautas da cidadania" no mar da educação: movimentos sociais, ONGs e fundações empresariais na escola pública brasileira. 204 f., Tese (Doutorado) Pontifícia Universidade Católica do Rio de Janeiro, Rio de Janeiro, 2011.

SAADS, Leila; NASCIMENTO, Líbia Rany Oliveira. Entre mulheres nômades: reflexões sobre o "sujeito feminista" e o diálogo entre diferentes na Marcha das Vadias - DF. Seminário Internacional Fazendo Gênero 10 (Anais Eletrônicos), Florianópolis, 2013.

SABINO, Maria Jordana Costa; LIMA, Patrícia Verônica Pinheiro Sales. Igualdade de gênero no exercício do poder In Revista Estudos Feministas, vol.23, nº. 3, Florianópolis Set - Dez., 2015.

SAFFIOTI, Heleieth. Gênero, patriarcado e violência. São Paulo: Editora Fundação Perseu Abramo (Coleção Brasil Urgente), 2004. 
SANTOS, Milton. Por uma outra globalização: do pensamento único à consciência universal. Rio de Janeiro: Record, 2000.

SANTOS, Silvana Mara de Morais dos; OLIVEIRA, Leidiane. Igualdade nas relações de gênero na sociedade do capital: limites, contradições e avanços In Revista Katálysis, v. 13, $\mathrm{n}^{\circ} .1,2010$.

SCOTT, Joan. Gênero: uma categoria útil para a análise histórica. Educação e Realidade, Porto Alegre, v. 16, n. 2, 1990.

SHIROMA, Eneida. Implicações da política de profissionalização sobre a gestão e o trabalho docente. Trabalho e educação, vol13, n.2, ago/dez 2004.

SILVA, Elenita Pinheiro de Queiroz. Tecendo percursos para pensar o corpo In 34a Reunião Anual - ANPEd. Natal, 2011. Anais. Rio Grande do Norte: ANPEd, 2011.

SOUSA, Fabiana Rodrigues de; OLIVEIRA, Maria Waldenez de. Contribuições da educação popular e fenomenologia para a pesquisa em educação realizada com prostitutas In 34${ }^{\mathbf{a}}$ Reunião Anual - ANPEd. Natal, 2011. Anais. Rio Grande do Norte: ANPEd, 2011.

SCWENGBER, Maria Simone Vione. As imagens e a educação generificada dos corpos In 36 ${ }^{\mathbf{a}}$ Reunião Anual - ANPEd. Goiânia, 2013. Anais. Goiás: ANPEd, 2013.

SZYMANSKI, Heloisa. Entrevista reflexiva: um olhar psicológico sobre a entrevista em pesquisa In SZYMANSKI, Heloisa; ALMEIDA, Laurinda Ramalho de; PRANDINI, REGO, Regina Célia Almeida (org.). A Entrevista na pesquisa em Educação - a prática reflexiva, $4^{\mathrm{a}}$ Ed., Brasília: Liber Livro, 2011.

VENDRAMINI, Célia Regina. Pesquisa e movimentos sociais In Educação e Sociedade: Campinas, vol. 28, n. 101, p. 1395-1409, set./dez, 2007.

WOODWARD, Kathtyn. Identidade e diferença: uma introdução teórica conceitual In SILVA, Tomaz Tadeu da (org.). Identidade e diferença: A perspectiva dos Estudos Culturais, 14 edição: Vozes, Petrópolis, RJ, 2014.

ZANTEN, Agnes van. Comprender $\mathbf{y}$ hacerse compreender: como reforzar la legitimidad interna y externa de los estúdios cualitativos In Educação e Pesquisa, vol. 30, num. 2,pp. 301-313, maio-ago, 2004. 


\section{Apêndices}

\section{1.}

\section{Termo de Consentimento Livre e Esclarecido}

PUC-Rio | Programa de Pós-Graduação em Educação

PUC

TERMO DE CONSENTIMENTO LIVRE E ESCLARECIDO | PROFESSORES

Prezada:

Vimos, por meio deste, convidar-lhe a participar voluntariamente da pesquisa apresentada a seguir.

Pesquisa: "Como se aprende a ser "vadia"? Práticas educativas de um movimento feminista.

Pesquisadores:

Mestranda: Carolyna Ferreira Barroca | carolynabarroca@gmail.com | Tel. (21) 98201-2829

Orientador: Prof. Dr. Marcelo Andrade | marcelo-andrade@ puc-rio.br | Tel. (21) 3527-1815

Justificativas: A pesquisa busca compreender o campo da educação não formal, ampliando discussões sobre questões relativas ao gênero e à sexualidade nos movimentos sociais.

Objetivos: O objetivo geral da pesquisa é identificar práticas educativas (intencionais e/ou não intencionais) existentes na Marcha das Vadias, com atuação na cidade do Rio de Janeiro.

Metodologia: entrevistas (áudio-gravação), com duração média de 50 minutos.

Riscos e Benefícios: É possível que ocorra algum tipo de constrangimento ao abordar temas relacionados a gênero e sexualidade, vistos que são polêmicos e particulares. Porém, os procedimentos levarão este risco em conta, respeitando as militantes voluntárias. Como benefício, consideramos que as participantes contribuirão para a compreensão de práticas educativas no movimento social que atuam.

Eu,

de maneira voluntária, livre e esclarecida, concordo em participar da pesquisa acima identificada. Estou ciente dos objetivos do estudo, dos procedimentos metodológicos, dos possíveis desconfortos com o tema, das garantias de confidencialidade e da possibilidade de esclarecimentos permanentes sobre os mesmos. Fui informada que se trata de pesquisa de mestrado em andamento no Programa de Pós-Graduação em Educação da PUC-Rio. Está claro que minha participação é isenta de despesas e que minha imagem e meu nome não serão publicados sem minha prévia autorização por escrito. Estou de acordo com a áudiogravação da entrevista a ser cedida para fins de registros acadêmicos. Estou ciente de que, em qualquer fase da pesquisa, tenho a liberdade de recusar a minha participação ou retirar meu consentimento, sem nenhuma penalização, prejuízo ou constragimento.

Carolyna Barroca, mestranda.

Marcelo Andrade, orientador.

[assinatura do responsável]

Nome completo:

E-mail: Tel.

Identificação (RG): | Rio de Janeiro, de de 2015 .

OBS.: Este termo é assinado em 2 vias, uma do/a voluntário/a e outra para os arquivos dos pesquisadores. 


\section{2.}

Ficha de Cadastro

\section{IDENTIFICAÇÃO}

NOME:

PSEUDÔNIMO PARA PESQUISA:

COR:

IDADE:

BAIRRO:

\section{FORMAÇÃO E ATUAÇÃO PROFISSIONAL}

ENSINO MÉDIO - ESCOLA:

ENSINO SUPERIOR - IES:

CURSO: ANO DA FORMAÇÃO:

PÓS-GRADUAÇÃO: NÃO ( ) SIM ( )

CURSO:

IES:

CURSO:

IES:

TRABALHA?

$\square$ Não. $\square$ Sim. Em que?

\section{MILITÂNCIA}

Que ano foi a sua primeira participação na Marcha das Vadias?

Quais os anos nos quais você construiu a Marcha das Vadias?

Quais anos você participou da Marcha?

Você utiliza o grupo do Facebook para se informar sobre eventos da Marcha?

$\square$ Não. $\square$ Sim. Com que frequência?

Você utiliza a página do Facebook para se informar sobre eventos da Marcha?

$\square$ Não. $\square$ Sim. Com que frequência?

PARTICIPA DE OUTROS ESPAÇOS DE MILITÂNCIA?

$\square$ Não. $\square$ Sim? Qual (is)? 


\section{3. \\ Roteiro de Observação}

AMBIENTE

- Descrição (descrever o que há naquele espaço ou onde é feita as reuniões)

- Material disponível sobre feminismo (se há um lugar para guardar os materiais, onde estão, quais são, de quando são)

- Apropriação do espaço

- Como foi organizada a reunião? (todas que comentaram no grupo do facebook foram?

PESSOAS

- Quantas pessoas são? (faixa etária, profissão)

- Tem homens? Como são recebidos? (cis?trans?homo?)?

- Tinha outros movimentos presentes? Se apresentaram como integrantes destes movimentos? Solicitaram participar enquanto movimento? Como atuaram? Teve dissidências? Concordâncias?

\section{DINÂMICA}

- Existe apresentação entre as presentes? O que mencionam?

- Como se cumprimentam?

- Como as novas integrantes são tratadas?

- Como organizam as falas? (inscrições, uma fala de cada vez sem inscrição? respeitam os momentos de falas das colegas?)

- Todas opinam?

- Há discordânias? Como lidam com elas?

- Existiram disputas internas?

- Como as sugestões são incorporadas?

- Quais as discussões mais relevantes? Quais se alongaram mais? Quais foram as discussões menores?

- O assunto principal é a organização da Marcha?

- Quais os pontos de pauta?

- Além da organização da Marcha, há outros assuntos presentes? Quais? Há espaços para dasabafos?

RESPONSÁVEL

- Quem foi a responsável pela reunião? Teve liderança? Como ocorreu?

- Como quem liderava/ era responsável moderou o encontro?

- Alguém se destacou? de como forma? como os participantes atuaram diante dessa postura? Quais as falas que mais se destacaram destas?

PRÁTICAS PEDAGÓGICAS

- Quais estratégias "didáticas" foram usadas?

- Vocabulário utilizado

- Quais as atividades realizadas?

- Falam sobre suas rotinas? (exemplos de como ser o não ser)

- Organizam formas de expansão da reunião ou de convite para integração da Marcha?

- Definem sobre a publicidade da Marcha? Como decidem? Quais as formas de publicidade escolhidas? Por quê?

- Há algum fechamento que simbolize uma síntese?

\section{RECURSOS EDUCATIVOS}

- Falam sobre outras marchas? O que mencionam? Há exemplaridade nessas falas ("agimos assim e deu certo" ou coisa do tipo)

- Existe algum material (texto, repostagem, afins)? Quem selecionou? Quais os motivos apresentados para sua utilização?

- Discutem ou mencionam algum texto ou autor?

- Descrever quais e como ocorre a discussão dos textos e do encontro em geral

\section{PESQUISA}

- Como fui recebida enquanto pesquisadora? 
- Se disponbilizaram para entrevista? 


\subsection{Roteiro de entrevista}

\section{A LUTA DAS MULHERES}

1. Como você começou a se interessar por questões feministas? Como e quando a luta das mulheres começou a fazer parte de sua vida de maneira mais clara?

2. Como você avalia a luta das mulheres hoje? Quais os principais avanços e as principais dificuldades?

\section{MARCHA DAS VADIAS}

3. Como foi o contato com a Marcha das Vadias? Como você soube? Como começou a participar?

4. Há quanto tempo você está na Marcha? Como foi a sua entrada no movimento? Como você avaliaria os primeiros momentos no movimento?

5. Quais atividades você desempenha ou já desempenhou? Como é o seu envolvimento com a Marcha? Participa/participou da organização da Marcha?

Acompanha/acompanhou o grupo do Facebook e a página? Com que frequência? De que forma?

6. Das tarefas e organizações de eventos, o que você mais gosta de fazer? Por quê? E o que menos gosta de fazer? Por quê?

7. O que você considera mais importante na Marcha? O que te marcou/marca mais? O que te desperta mais interesse?

8. Se você pudesse resumir a Marcha das Vadias em três palavras, quais palavras você diria? Por quê?

9. Você avalia que existe alguma dificuldade na construção movimento? Por quê?

10.E as facilidades? Você avalia que a construção do movimento possui facilidades? Quais?

\section{A MARCHA E A EDUCAÇÃO}

11. Você aprendeu alguma coisa com a Marcha? Se sim, o quê? De que forma se dá esse aprendizado?

12. Como você leva este aprendizado para sua vida? Em que te ajuda, por exemplo, nos estudos, no trabalho? Mudou algo em suas amizades e relacionamentos pessoais e familiares? Se sim, dê exemplos.

13.O que você mais aprende nas reuniões, nas atividades públicas e nos fóruns virtuais? Quais desses espaços da Marcha das Vadias você considera que sejam mais educativos para as mulheres? Por quê?

14.E você considera que "ensina" alguma coisa nas reuniões, atividades públicas e nos fóruns virtuais que participa? Se sim, como?

15. A Marcha tem algum propósito educativo? Se sim, o que a Marcha pretende "ensinar"? Para quem? Como? Quais seriam os resultados obtidos?

16. Se fosse possível, você sugeriria alguma atividade de cunho educativo para as atividades da Marcha? Se sim, como seriam estas atividades?

17. Se você tivesse que preencher estas frases, o que você diria?

18. "Na Marcha das Vadias se aprende a ..."

19. "Na Marcha das Vadias se ensina a ..." 


\section{5.}

\section{Lista de códigos}

\begin{tabular}{|c|c|c|}
\hline Código & Descrição & $\begin{array}{l}\text { Número de } \\
\text { Recorrências }\end{array}$ \\
\hline 1aacha & Falas relacionadas à primeira marcha & 35 \\
\hline Anarcofeminismo & $\begin{array}{l}\text { Falas que apresentam uma perspectiva } \\
\text { anarquista de atuação feminista }\end{array}$ & 5 \\
\hline Aprendizado & $\begin{array}{l}\text { Falas que apontam aprendizados obtidos no } \\
\text { movimento }\end{array}$ & 60 \\
\hline Atividades & $\begin{array}{l}\text { Atividades desempenhadas pela entrevistada } \\
\text { no moivimento }\end{array}$ & 20 \\
\hline $\begin{array}{l}\text { Atividades } \\
\text { Sugestão }\end{array}$ & $\begin{array}{l}\text { Sugestão de atividades de cunho educativo } \\
\text { para o movimento }\end{array}$ & 11 \\
\hline Bandeiras & $\begin{array}{l}\text { Falas que apresentam bandeiras de luta do } \\
\text { movimento }\end{array}$ & 12 \\
\hline Conflitos & $\begin{array}{l}\text { Falas que evidenciam conflitos vivenciados } \\
\text { dentro do movimento }\end{array}$ & 44 \\
\hline Contrariedade & $\begin{array}{l}\text { Falas que evidenciam outras atuações } \\
\text { feministas nas quais o movimento se opõe }\end{array}$ & 6 \\
\hline Corpo - controle & $\begin{array}{l}\text { Falas que evidenciam a perspectiva das } \\
\text { entrevistadas sobre o controle social dos } \\
\text { corpos }\end{array}$ & 21 \\
\hline Desconstrução & $\begin{array}{l}\text { Falas que evidenciam os processos de } \\
\text { desconstrução vivenciados pelas entrevistadas }\end{array}$ & 19 \\
\hline Dia da Marcha & Falas que abordam o dia da marcha & 15 \\
\hline Dificuldades & $\begin{array}{l}\text { Falas que apontam as dificuldades de } \\
\text { construção do movimento }\end{array}$ & 24 \\
\hline Empoderamento & 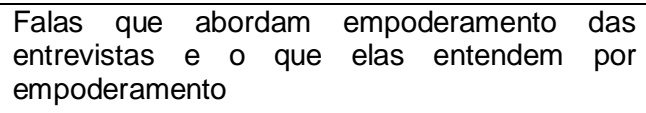 & 44 \\
\hline $\begin{array}{l}\text { Ensino- } \\
\text { Aprendizagem }\end{array}$ & $\begin{array}{l}\text { Falas que apontam o que as entrevistadas } \\
\text { consideram que ensinam ao movimento }\end{array}$ & 35 \\
\hline $\begin{array}{l}\text { Espaços } \\
\text { Educativos }\end{array}$ & $\begin{array}{l}\text { Falas que apontam quais espaços do } \\
\text { movimento são educativos }\end{array}$ & 23 \\
\hline Feminismo & $\begin{array}{l}\text { Falas em que as entrevistadas apontam suas } \\
\text { considerações sobre o movimento feminista }\end{array}$ & 53 \\
\hline Fora da Marcha & $\begin{array}{l}\text { Falas em que as entrevistadas apontam o que } \\
\text { levam da militância interna para outros espaços }\end{array}$ & 23 \\
\hline Gênero & $\begin{array}{l}\text { Falas que apontam o que as entrevistadas } \\
\text { entendem sobre gênero }\end{array}$ & 25 \\
\hline Homem feminista & $\begin{array}{l}\text { Falas que abordam a presença de homem no } \\
\text { movimento feminista e na Marcha das Vadias } \\
\text { do Rio de Janeiro }\end{array}$ & 8 \\
\hline Homossexualidade & Falas que abordam sobre homossexualidade & 1 \\
\hline Horizontalidade & $\begin{array}{l}\text { Falas sobre as facilidades e dificuldades de se } \\
\text { construir a horizontalidade no movimento }\end{array}$ & 25 \\
\hline
\end{tabular}




\begin{tabular}{|c|c|c|}
\hline Importância & $\begin{array}{l}\text { Falas sobre a importância do movimento para } \\
\text { as entrevistadas }\end{array}$ & 20 \\
\hline Interseciocnalidade & $\begin{array}{l}\text { Falas que abordam sobre a perspectiva } \\
\text { intersecional do movimento }\end{array}$ & 54 \\
\hline Machismo & Falas sobre machismo & 13 \\
\hline Maternidade & Falas sobre a maternidade no feminismo & 7 \\
\hline Militância & $\begin{array}{l}\text { Falas sobre a militância das entrevistadas na } \\
\text { Marcha das Vadias e fora dela }\end{array}$ & 44 \\
\hline Performances & Falas sobre performances artísticas na marcha & 7 \\
\hline Prostituição & $\begin{array}{l}\text { Falas sobre as considerações } \\
\text { prostituição na militância da Marcha das Vadias }\end{array}$ & 9 \\
\hline Redes & $\begin{array}{l}\text { Falas associadas ao conceito de Movimento } \\
\text { em Redes de Castells }\end{array}$ & 37 \\
\hline Repercussões & $\begin{array}{l}\text { Falas que abordam sobre as repercussões da } \\
\text { marcha na mídia }\end{array}$ & 6 \\
\hline Repressão & $\begin{array}{l}\text { Falas que falam da repressão instituicional ao } \\
\text { evento da marcha em Copacabana }\end{array}$ & 7 \\
\hline Sexualidade & Falas sobre o conceito de sexualidade & 7 \\
\hline Socialização & $\begin{array}{l}\text { Falas associadas ao conceito de socialização } \\
\text { política de Mesquita e Castells }\end{array}$ & 25 \\
\hline Transfeminismo & $\begin{array}{l}\text { Fala sobre as pessoas trans dentro do } \\
\text { feminismo }\end{array}$ & 9 \\
\hline Três palavras & $\begin{array}{l}\text { Definição da Marcha das Vadias em três } \\
\text { palavras pelas entrevistadas }\end{array}$ & 11 \\
\hline Violência & Falas sobre violência simbólica e física & 3 \\
\hline
\end{tabular}

Fonte: BARROCA, 2016. 
Anexos

\section{1.}

\section{Parecer do Comitê de Ética da PUC-Rio}

CICEVRAc.11/2015

Rio de Janeiro, 10 de abril de 2015

Da: Comissão de Ética em Pesquisa da PUC-Rio Ilda Lopes Rodrigues da Silva

Para: Departamento de Educação da PUC-Rio. Prof. Marcelo Andrade

Prezado Professor,

Acusamos o recebimento do projeto intitulado "Como se aprende a ser "vadia"? Práticas educativas de um movimento feminista" de autoria da mestranda Carolyna Ferreira Barroca, sob sua orientação, para submissão desta Comissão.

Após o exame do projeto e do Termo de Consentimento Livre e Esclarecido fêz-se algumas observações que solicitamos sejam respondidas.

\section{Observações:}

Quanto ao Termo de Consentimento Livre e Esclarecido:

1. Acrescentar os meios de comunicação da pesquisadora responsável (telefone e e-mail);

2. Informar que o participante pode interromper a pesquisa sem sofrer qualquer penalização ou constrangimento;

3. Registrar que o documento é assinado em duas vias, uma fica com a pesquisadora e a outra com o participante da pesquisa;

4. Acrescentar um espaço para o nome e assinatura da pesquisadora.

$\mathrm{Na}$ oportunidade, ficamos à disposição para fornecer quaisquer outros esclarecimentos que se fizerem necessários ao assunto em pauta.

Atenciosamente,

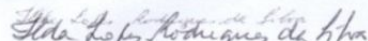

Ilda Lopes Rodrigues da Silva

Comissão de Ética em Pesquisa da PUC-Rio

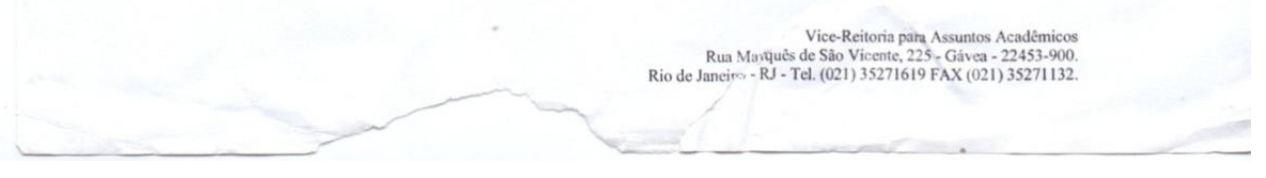




\section{2. \\ Manifesto 2014}

MARCHA DAS VADIAS DA CIDADE DO RIO DE JANEIRO

A Marcha das Vadias do Rio é organizada por feministas autônomxs que lutam contra a violência sexual e de gênero e a favor da autonomia dos corpos. Somos chamadas de "vadias" nos espaços em que circulamos porque vivemos numa sociedade machista, racista e centrada na heterossexualidade, que quer controlar os nossos corpos. $\mathrm{O}$ Ministério da Justiça divulgou no fim de 2013 que 50 mil mulheres são estupradas por ano no Brasil! Uma pesquisa recente do IPEA mostrou que $26 \%$ dxs brasileirxs concordam que mulheres que usam roupas que mostram o corpo merecem ser atacadas! Marchamos pelo fim da violência sexual contra as mulheres e contra a culpabilização das vítimas!

Somos chamadas de vadias quando usamos roupas curtas e também quando usamos roupas compridas, somos chamadas de vadias quando andamos pelas ruas de noite e quando andamos pela rua de dia, somos chamadas de vadias quando denunciamos o estupro e nos culpam pela violência que sofremos, somos chamadas de vadias quando denunciamos o assédio sexual no transporte público e a violência dentro de casa, somos chamadas de vadias quando dizemos "NÃO", somos chamadas de vadias quando dizemos "sim" ao prazer, somos chamadas de vadias quando "ousamos" fazer escolhas de forma autônoma. Somos chamadas de vadias apenas porque somos MULHERES. Marchamos para dizer NÂO ao controle da nossa sexualidade e para dizer NÂO ao eterno julgamento e depreciação do feminino! Sabendo que o termo "vadia" tem significados diversos para corpos diferentes, ressignificamos "vadia" como símbolo de nossa luta por liberdade para experimentar nossos corpos e afetos da maneira que desejarmos. Não queremos ser respeitáveis, exigimos ser respeitadas! Se ser livre é ser vadia, então somos todas vadias!

Fazemos parte da construção de um mundo livre de violência para todas as mulheres (cis e trans*), um mundo onde nenhuma vítima seja culpabilizada, onde não haja vítimas. Combatemos todas as formas de opressão: machismo, racismo, lesbofobia, transfobia, bifobia, exclusão das pessoas com deficiência (ou capacitismo), violência de classe e outras. Nossos princípios são liberdade, horizontalidade e autonomia.

Em 2014, a Marcha das Vadias ocupa as ruas, as esquinas, os bares e os becos da cidade do Rio de Janeiro pelas seguintes razões:

1) Com os grandes eventos sediados no país e na cidade, a desigualdade, a exclusão e a violência contra a população são agravadas. Diante disso:

a. Denunciamos o racismo que mulheres negras sofrem ao serem vistas como objeto de consumo, facilitando a exploração sexual. Exigimos que as mulheres negras sejam vistas como seres humanos e não como "pontos turísticos". É urgente que se reconheçam as diferentes vozes e lugares ocupados pelas mulheres negras na sociedade!

b. Denunciamos que as mulheres que moram em favelas e periferias são profundamente atingidas por várias formas de violência: são arrancadas das suas casas e 
de suas raízes, têm filhxs e companheirxs assassinadxs pela polícia, são violentadas pelos agentes de "segurança". Nunca esqueceremos o assassinato brutal de mulheres, como o de Cláudia da Silva Ferreira. Destacamos também a enorme força com que as mulheres NÃO PACIFICADAS defendem suas causas, organizando-se e exigindo direitos.

c. Repudiamos o projeto de cidade que marginaliza e criminaliza a prostituição. No caso da remoção forçada do prédio da Caixa Econômica, do centro de Niterói, vimos como mulheres trabalhadoras foram expulsas dos seus locais de moradia e trabalho, estupradas e roubadas, em uma ação ilegal do Estado. Novamente, como Marcha das Vadias do Rio de Janeiro, lembramos que a prostituição nunca foi ilegal no Brasil e reafirmamos a necessidade da sua regulamentação, reivindicação do movimento de prostitutas. Exigimos que a cidadania seja garantida já!

d. Sublinhamos a alarmante violência transfóbica persistente na nossa sociedade, que retira o direito à cidade dos corpos que fogem ao padrão de gênero estabelecido. Afirmamos nosso compromisso com os direitos das pessoas a se identificarem com o gênero que quiserem, inclusive nenhum. Basta de invisibilidade! Basta de violência! Basta de ódio e transfobia!

e. Denunciamos o assédio, as agressões, os estupros "corretivos" e outros tipos de violência sofridos por lésbicas e mulheres bissexuais em todos os espaços, tanto públicos quanto privados. Por isso, rompemos o silêncio, destacando que esta violência é invisível aos olhos da sociedade e das suas instituições. Exigimos liberdade e segurança para que lésbicas e mulheres bissexuais possam expressar seu afeto em todo e qualquer lugar!

2) Denunciamos a manutenção de atitudes machistas e misóginas (atos que representam ódio à condição feminina) nos movimentos sociais de esquerda: assédio moral e sexual, silenciamento das vozes das mulheres, divisão sexual de tarefas. Que as pautas feministas sejam incorporadas e PRIORIZADAS na construção de uma sociedade mais justa e igualitária.

3) Reivindicamos a garantia dos direitos sexuais e dos direitos reprodutivos. Exigimos a não interferência das religiões nas políticas públicas e na legislação. Mais uma vez, exigimos o direito aos nossos corpos. Repudiamos os retrocessos em relação ao aborto no Brasil, como a revogação da portaria 415/2014 do Ministério da Saúde, que reafirmava e regulamentava os princípios de humanização, qualidade e segurança do atendimento aos casos de aborto legal no SUS.

Demandamos a ampliação do acesso e a boa qualidade dos serviços de saúde integral para as mulheres e pessoas gestantes, incluindo acesso a informação e métodos de qualidade sobre contracepção e planejamento familiar. Da mesma forma que nenhuma mulher deve ser obrigada a ser mãe, aquelas que fazem esta escolha devem ter a autonomia de seus corpos respeitada, inclusive para decidir as condições em que desejam gestar e parir. Exigimos aborto legal, seguro, raro e gratuito, assim como partos seguros e sem violência física e psicológica. Nossos corpos, nossas regras. 
A cor da pele não pode ser motivo de estupro!! O local de moradia não pode ser motivo de estupro!! A profissão não pode ser motivo de estupro!! A identidade de gênero não pode ser motivo de estupro!! A orientação sexual não pode ser motivo de estupro!! NADA PODE SER MOTIVO DE ESTUPRO!!!"

Marcha das Vadias do Rio de Janeiro 2014

Dia 9 de agosto

Concentração $13 \mathrm{~h}$

Posto 5 - Praia de Copacabana 


\section{3. \\ Manifesto 2015}

\section{MARCHA DAS VADIAS 2015 - MANIFESTO}

A cor da pele não pode ser motivo de estupro!! O local de moradia não pode ser motivo de estupro!! A profissão não pode ser motivo de estupro!! A identidade de gênero não pode ser motivo de estupro!! A orientação sexual não pode ser motivo de estupro!! NADA PODE SER MOTIVO DE ESTUPRO!!!"

No próximo sábado, dia 14 de Novembro, a Marcha das Vadias do Rio de Janeiro realiza sua quinta edição, chamando a atenção para o alto índice de estupros no estado e a cultura de culpabilização das vítimas de violência sexual.

A Marcha das Vadias do Rio é organizada por pessoas feministas autônomas que lutam contra a violência sexual e de gênero e a favor da autonomia dos corpos, inclusive do direito a livre expressão e autoidentificação de gênero, como no caso de travestis, transexuais, transgêneros e intersexuais. A marcha reivindica a ressignificação do termo "vadia" como símbolo de luta pela liberdade de todas as pessoas para experimentarem seus corpos, desejos, sexualidades e afetos da maneira que quiserem e decidam.

A Marcha das Vadias de 2015 traz a construção de cinco anos de ocupação de ruas, esquinas, bares e becos da cidade, quando chamamos atenção para o lema "Meu corpo minhas regras", pelo qual repudiamos e rejeitamos qualquer intervenção ou imposição do Estado, da igreja ou de qualquer sorte sobre ou a respeito de nossos corpos:

Em 2011 marchamos em Copacabana contra a violência de gênero e o abuso sexual naturalizados pela cultura de estupro. Nenhuma mulher "está pedindo" ou "merece" ser estuprada;

Em 2012 tomamos as ruas pela legalização do aborto, pela regulamentação da prostituição, contra o Cadastro Nacional de Gestantes, contra a violência contra a mulher, contra a lesbofobia, a transfobia, a homofobia, a bifobia e o racismo;

Em 2013, ano em que a cidade recebeu a Jornada Mundial da Juventude, reforçamos nosso combate às violências sexuais e de gênero, à criminalização do aborto, à interferência da religião nas políticas públicas e nos corpos das mulheres e pessoas trans;

Em 2014, ano em que o Brasil recebeu a Copa do Mundo de futebol, tomamos as ruas contra as violentas investidas do Estado contra as populações periféricas nas remoções de favelas e ocupações e continuamos batalhando pela regulamentação da prostituição, pela garantia dos direitos sexuais e reprodutivos e pela laicidade do Estado. 
Hoje chamamos a atenção de todas as pessoas à urgente necessidade de nos posicionarmos contra o conservadorismo que se amplia no Congresso Nacional.

A Constituição Federal traz, dentre seus princípios democráticos, a laicidade e a não discriminação e temos acompanhado o pavoroso desrespeito às conquistas históricas dos movimentos sociais diariamente naquela Casa que deveria nos representar. Acreditamos na construção da política pelo debate entre os diferentes grupos que compõem a sociedade e temos acompanhado o enorme retrocesso legislativo em busca de restringir a pluralidade de nossas vidas, quando senadores e deputados vomitam sem modéstia declarações misóginas, transfóbicas, lesbofóbicas, homofóbicas e racistas.

Em 21 de Outubro deste ano a Comissão de Constituição e Justiça da Câmara dos Deputados aprovou projeto de lei 5.069/2013, de autoria do presidente da Câmara, Eduardo Cunha. Esse projeto proíbe a venda de pílulas do dia seguinte e impõe medidas que dificultam o acesso ao aborto por mulheres que foram vítimas de estupro, projeto que fere princípios da dignidade humana da mulher e nos coloca, mais uma vez, sob crivo da autoridade policial e do judiciário para que se comprove a nossa inocência por um crime do qual somos vítimas. Uma semana depois, no dia 28 de Outubro, mais de três mil mulheres tomaram as ruas do centro da cidade do Rio de Janeiro em protesto ao projeto, pela legalização do aborto e exigindo a saída de Eduardo Cunha.

Salientamos a importância da legalização do aborto e acessibilidade de métodos abortivos, bem como de partos sem violência, para que ser mãe/pai seja uma escolha e não uma consequência pesarosa; do reconhecimento da identidade de gênero de pessoas trans sem obstáculos, para que ser homem ou mulher seja uma escolha consciente e não biologizante; do combate à cultura de estupro e do acesso à informação e acolhimento às vítimas desse odioso crime; da necessidade do ensino nas escolas pautar temáticas associadas a gênero, sexualidades, culturas e religiões de matrizes africanas, indígenas e orientais; para que as crianças e adolescentes conheçam as múltiplas possibilidades de vida e invistamos em um futuro com menos violência e desigualdades.

Todas e todos somos responsáveis pelo sangue que tem sido derramado e precisamos nos posicionar contra toda forma de violência e apagamento de vida que temos presenciado. Precisamos renovar nossa paixão pela luta nos processos políticos que envolvem a garantia de direitos, precisamos desafiar a ordem instituída e buscar resultados reais.

Somos chamadas de "vadias" nos espaços em que circulamos porque vivemos numa sociedade machista, racista e centrada na cisgeneridade e na heterossexualidade, que quer controlar a forma como nos vestimos, nos comportamos e até por quem sentimos desejo e a quem amamos. Ouvimos diariamente que temos que ser "vadias na cama e damas em sociedade", que "tudo bem ser lésbica, bissexual ou gay, mas não 
precisa sair na rua de mãos dadas com alguém do mesmo sexo", que "tudo bem ser trans, desde que seja discreta". Nos posicionamos contra esse controle e reivindicamos nosso direito à vadiagem pública, que entendemos como nosso direito a viver como queremos. Não vamos nos limitar a quatro paredes.

Dia 14 de novembro de 2015 vamos às ruas de Copacabana e convocamos todas as pessoas comprometidas com o combate às injustiças e desigualdades sociais para que marchemos em combate às ideologias que buscam nos padronizar e neutralizar nossas diferenças para que possamos promover a singularidade que cada pessoa tem potência de construir sobre si e sobre o mundo. Convocamos todas e todos a ocuparem os espaços públicos do qual tentam nos retirar!

PRA RUA VADIAGEM!

Serviço:

Marcha das Vadias do Rio de Janeiro 2015

Dia 14 de novembro - Concentração 14h - Posto 4 - Praia de Copacabana 